\title{
At a Crossroads CONSEQUENTIAL TRENDS IN RECOGNITION OF COMMUNITY-BASED FOREST TENURE LFROM 2002-2017
}




\section{About the Rights and Resources Initiative}

The Rights and Resources Initiative (RRI) is a global coalition consisting of 15 Partners, 7 Affiliated Networks, 14 International Fellows, and more than 150 collaborating international, regional, and community organizations dedicated to advancing the forestland and resource rights of Indigenous Peoples and local communities. RRI leverages the capacity and expertise of coalition members to promote secure local land and resource rights and catalyze progressive policy and market reforms.

RRI is coordinated by the Rights and Resources Group, a non-profit organization based in Washington, DC. For more information, please visit www.rightsandresources.org.

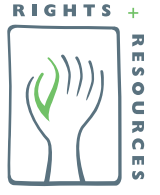

2715 M St NW

Suite 300

Washington, DC 20007

www.rightsandresources.org @RightsResources

\section{Partners}
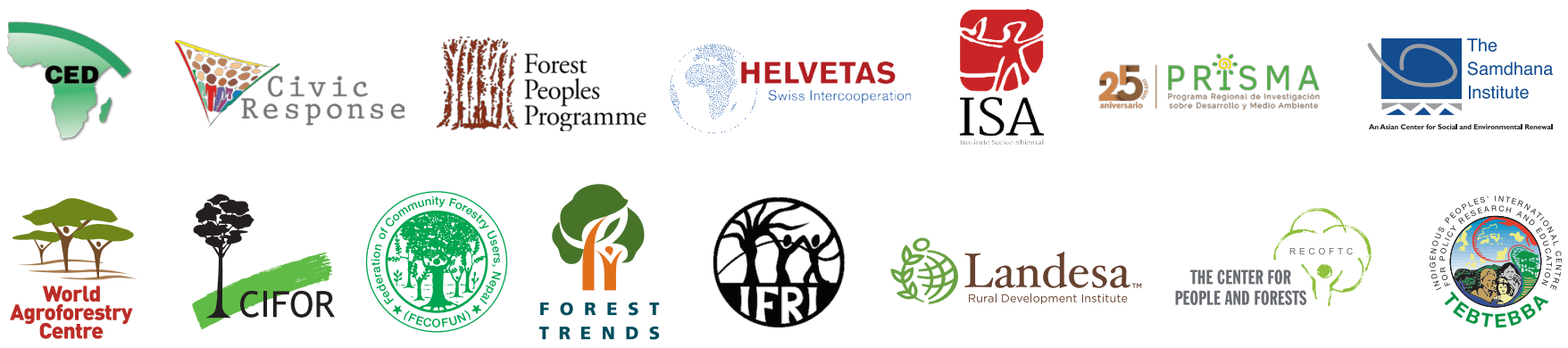

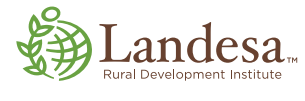
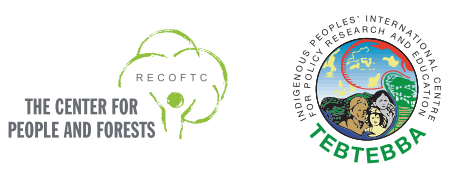

Affiliated Networks
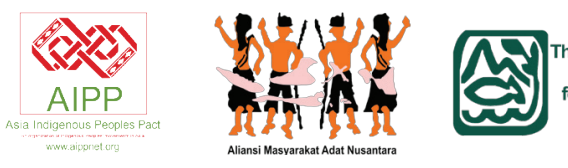

The International
Association
for the Study of
the Commons
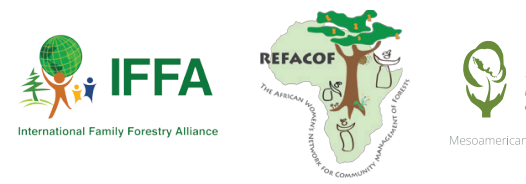

Alianza

Mesoamericana
de Pueblos y Bosques

\section{Sponsors}




\section{Acknowledgments}

Chloe Ginsburg and Stephanie Keene led the data analysis and authored the report. Important contributions to the research, data collection, analysis, content, and/or production of the report were provided by Alain Frechette, Donald Quinn-Jacobs, Solange Bandiaky-Badji, Omaira Bolaños, Kundan Kumar, Anne-Sophie Gindroz, Natalie Campbell, Patrick Kipalu, Silene Ramirez, Jenna DiPaolo Colley, Jamie Kalliongis, Lindsay Bigda, Lai Sanders, Luke Allen, and Andy White.

The authors wish to thank the following consultants: Fernanda Almeida, Ana Clara Simões, William Nikolakis, Evan Powell, and Sarah Weber, for their invaluable assistance to the initial data collection and analysis for this study.

The authors also wish to express their appreciation to the following individuals, who made significant contributions that improved the report: Liz Alden Wily, Julian Atkinson, Nurit Bensusan, Alfred Brownell, Brett Butler, Karol Boudreaux, Lucy Claridge, Simon Counsell, Peter Cronkleton, Kevin Currey, Andrew Davis, Peter DeMarsh, Terence Hay-Eddie, Yemi Katerere, Aung Kyaw Naing, Tom Lomax, Theron Morgan Brown, Warangkana Ratanarat, Peggy Smith, Tol Sokchea, Dang Thi Thu Thuy, and Phuc Xuan To.

The following experts contributed time, energy, and knowledge in providing access to and/or reviewing the area data and legal analyses that form the primary substance of this report: Vladimir Aguilar Castro, Tajudeen Amusa, José Aylwin Oyarzún, Andrea Baudoin Farah, Lisa Best, Patrice Bigombe Logo, Pradeepa Bholanath, C.R. Bijoy, Rajesh Bista, David Bray, Lief Brottem, Dominique Cagalanan, Wen Caiyun, José Luis Capella, León Jorge Castaños, Carlos Chex, Linn Christiensen, Andrew Cock, Lesley L. Daspit, Piergiorgio Di Giminiani, Chris Dickinson, Samuel Dieval, Patrick Durst, Richard Eba'a Atyi, Maria Fernandez-Gimenez, Colin Filer, Tim Forsyth, José Luis Freire Villacres, Yayoi Fujita Lagerqvist, Abdala Gaafar Mohamed Siddig, Marie Gagné, Yelena Gordeeva, Marcos Guevara, Richard Hackman, Zemen Haddis Gebeyehu, José Heder Benatti, Tuti Herawati, Rosemary Hill, Margaret B. Holland, Nancy Hudson-Rodd, Benjamin Ichou, Andrew Inglis, Akiko Inoguchi, Gladys Jimeno Santoyo, Ali Kaba, Peter Kanowski, Rico Kongsager, Victor Kawanga, Miles Kenney-Lazar, Felician Kilahama, Menglim Kim, Minkyung Kim, Jaana Korhonen, Nadine Laporte, Yann Le Polain de Waroux, Gun Lidestav, Arttu Malkamäki, Andiko Mancayo, Sofía Marinaro, Francis Markham, Musingo Tito E. Mbuvi, Ana Mariana Mendoza Albinagorta, Peter May, Charles Meshack, Richard Metcalf, Yassin Mkwizu, Albeiro Moya Mena, Vanda Narciso, Franck Ndjimbi, Rod Nixon, Edwin Ogar, John Palmer, Daniel Penteado, Paolo Perasso Cerda, Marjolaine Pichon, Maureen Playfair, Eugenia Ponce de León, Matthew Pritchard, Vanda Radzik, Keshav Raj Kanel, Luis Guillermo Ramírez Porres, Pranab Ranjan Choudhury, Bernardo Ribeiro de Almeida, Francisco Rivas Ríos, Lucy Rocío del Carmen Malleux Hernani, Maud Salber, Naya Sharma Paudel, Phil Shearman, Jiang Shiguo, Nikolay Shmatkov, Cassian Sianga, Mwape Sichilongo, Stephen Siebert, Carolos Solis, Charles Sossou, Pedro Damião Sousa Henriques, Ana Spalding, Caleb Stevens, Yufang Su, Yogeswaran Subramaniam, Daniel Suman, Mohyeldeen Taha, Lauri Tamminen, Sara Teitelbaum, Karma Jigme Temphel, Eyob Tenkir, Aime Tillett, Jordan Treakle, Khongor Tsogt, Froyla Tz'alam, Tungalag Ulambayar, Tanja Venisnik, Jussi Viitanen, Joel Wainwright, Pedro Walpole, Xiaoli Wang, Andrew Wells-Dang, Josef Weyns, Kevin Woods, Stephen Wyatt, Utako Yamashita, and Katani Zephania.

Any omissions of contributors are unintentional, and any errors are the authors' own.

Design and layout by Publications Professionals. 


\section{Table of Contents}

\section{REPORT}

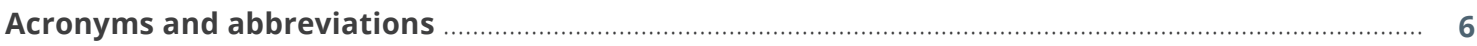

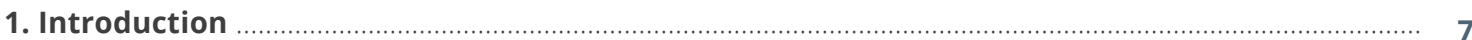

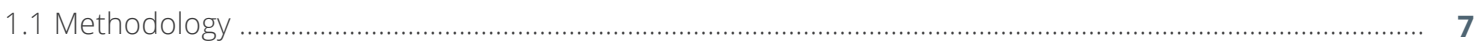

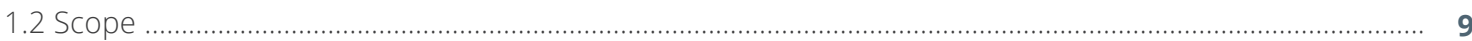

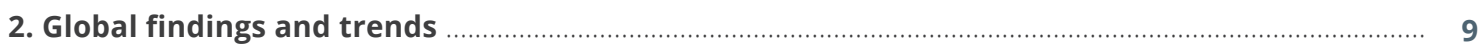

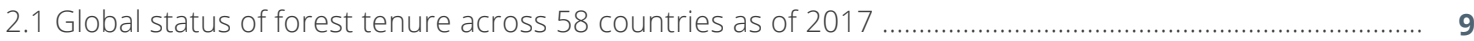

2.2 Global trends in forest tenure across 41 complete case countries, 2002-2017 ................................... 11

2.3 Trends in 33 complete case LMICs in Africa, Asia, and Latin America ................................................... 14

3. Regional trends across 33 complete case LMICs in Africa, Asia, and Latin America ................. 17

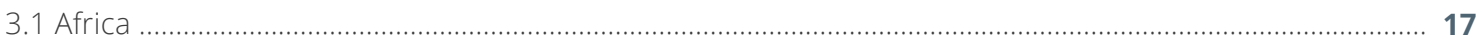

Angola, Cameroon, Central African Republic, Democratic Republic of the Congo, Ethiopia, Gabon, Gambia, Republic of the Congo, Senegal, Tanzania, Zambia

3.2 Asia

Bhutan, Cambodia, China, India, Indonesia, Lao PDR, Mongolia, Myanmar, Nepal, Papua New Guinea,

Philippines, Thailand, Vietnam

3.3 Latin America

Bolivia, Brazil, Colombia, Costa Rica, Guyana, Honduras, Mexico, Peru, Suriname

4. Progress toward RRI and global targets

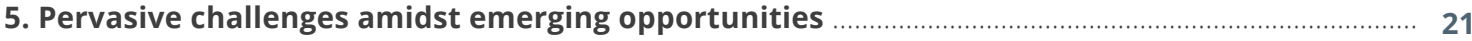

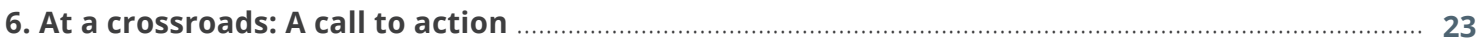

\section{ANNEX}

Annex: Technical notes

\section{TABLES}

Table 1: Statutory forest tenure across 58 countries, 2002-2017

Table 2: Formal definitions and available area of "smallholder forest ownership" in 9 countries as of 201716

\section{BOXES}

Box 1: Critical and consequential data gaps on smallholder forest ownership ........................................... 15

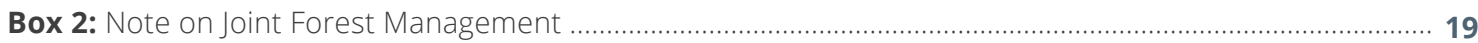

Box 3: Evictions and violence against forest communities persist in the name of conservation ....................22

\section{FIGURES}

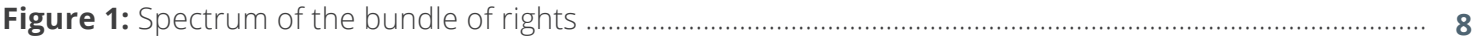

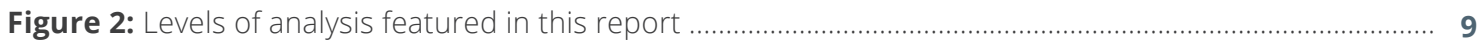

Figure 3: Global status of statutory forest tenure in 58 countries as of 2017 by percent .............................12

Figure 4: Global change in statutory forest tenure in 41 complete case countries by percent, 2002-2017 .. 12 
Figure 5: Change in statutory forest tenure in 33 complete case LMICs by percent, 2002-2017 ................... 17

Figure 6: Regional trends across complete case LMICs by percent, 2002-2017 .......................................... 18

Figure 7: RRI targets and trends in tenure recognition in 33 LMICS, 2002-2017 ............................................ 20

\section{ENDNOTES}

Report endnotes

Table endnotes 32

Box endnotes 


\section{Acronyms and abbreviations}

\begin{tabular}{|c|c|}
\hline ACHPR & African Court on Human and Peoples' Rights \\
\hline CADTs & Certificates of Ancestral Domain Titles (Philippines) \\
\hline CBTR & community-based tenure regime \\
\hline $\mathrm{CRL}$ & Community Rights Law (Liberia) \\
\hline DRC & Democratic Republic of the Congo \\
\hline ER-PD & Emissions Reductions Program Document \\
\hline EU & European Union \\
\hline FCPF & Forest Carbon Partnership Facility \\
\hline ha & hectares \\
\hline HICS & high-income countries \\
\hline JFM & joint forest management \\
\hline Lao PDR & Lao People's Democratic Republic \\
\hline LMICs & low- and middle-income countries \\
\hline Mha & millions of hectares \\
\hline NYDF & New York Declaration on Forests \\
\hline $\mathrm{RRI}$ & Rights and Resources Initiative \\
\hline SABLS & State Agricultural Business Leases \\
\hline SDGS & Sustainable Development Goals \\
\hline UN-REDD & $\begin{array}{l}\text { United Nations Collaborative Programme on Reducing Emissions from Deforestation and Forest } \\
\text { Degradation in Developing Countries }\end{array}$ \\
\hline VGGT & $\begin{array}{l}\text { Voluntary Guidelines on the Responsible Governance of Tenure of Land, Fisheries and Forests } \\
\text { in the Context of National Food Security }\end{array}$ \\
\hline
\end{tabular}




\section{Introduction}

Tenure reforms recognizing the rights of Indigenous Peoples, local communities, rural women, and smallholders are a prerequisite for the realization of the Sustainable Development Goals (SDGs), including poverty eradication (Goal 1), food security (Goal 2), gender equality and women's empowerment (Goal 5), inclusive economic growth (Goals 8 and 10), climate change mitigation and adaptation (Goal 13), sustainable resource use (Goal 15), and peace and justice (Goal 16). Y Yet despite the substantial forest area held, claimed, and managed by Indigenous Peoples, local communities, and rural women, the vast majority of the world's forests formally remain under government administration as national or provincial forests, protected areas, or forests allocated to third parties under concessions. Given evidence that deforestation rates are often lower and carbon sequestration greater in forests where Indigenous Peoples' and local communities' rights are legally recognized,"i there is an urgent need to scale up tenure reform in order to safeguard the world's remaining forests.

Despite ambitious international commitments to protect and restore the world's forests and biodiversity through the Paris Agreement, Bonn Challenge, New York Declaration on Forests (NYDF), and Aichi Biodiversity Targets, deforestation continues unabated. The FAO's Global Forest Resources Assessment 2015 reports that net forest area loss remained constant over the decade from 2005-2015.iii However, recently released data indicates a sharp uptick in tropical forest cover loss since 2016, with especially notable increases in Colombia and the Democratic Republic of the Congo (DRC). iv Persistent pressure on the world's tropical forests not only undermines international efforts to halt global climate change, but also threatens the Indigenous Peoples, local communities, and rural women who depend on these vital ecosystems for their livelihoods and culture. A confluence of mounting resource scarcity and heightened efforts by governments to suppress environmental social movements made 2017 the deadliest year on record for land and environmental defenders, with 207 women and men-one quarter of whom were indigenous-killed for protecting their lands, forests, and waters.

This analysis reports on trends in global forest tenure over the fifteen-year period from 2002-2017. It is the fourth in a series of analyses monitoring the legal recognition of forest tenure around the world according to four categories of legally recognized (statutory) forest tenure: government administered, designated for Indigenous Peoples and local communities, owned by Indigenous Peoples and local communities, and privately owned by individuals and firms.

As this analysis shows, governments are slow to recognize Indigenous Peoples', local communities', and rural women's rights to their forestlands. Findings indicate that the global slowdown in tenure recognition

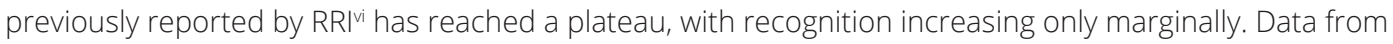
41 countries permitting an analysis of trends over time indicates that just over 15 percent (521 mha) of total forest area in those countries was legally owned by and designated for Indigenous Peoples and local communities as of 2017-an increase of only 5.6 percent since 2013. Notwithstanding the limited progress overall, emerging evidence and opportunities provide reason for hope: across the same 41 countries, two-thirds of the advancement in community tenure between 2013-2017 relate to increases in community forest ownership, with over 90 percent of this progress stemming from low- and middle-income countries (LMICs) in Africa, Asia, and Latin America. Moreover, recent laws in a number of countries establish new legal pathways for communities to own their forests under national law. Together, these advancements signal possible movement toward the recognition of additional and more robust forest tenure rights for Indigenous Peoples and local communities.

\subsection{Methodology}

The methodology underlying this report is based on a bundle-of-rights approachvii that was originally developed in the 2002 publication by Forest Trends, Who Owns the Word's Forests?, viii and has been adapted over time. The four categories below classify forest tenure according to the rights-holder and specific legal entitlements recognized by national-level laws and regulations:

- Category 1 - Government Administered: Forestlands under this category are legally claimed as exclusively belonging to the state. Community-based rights to access and/or withdrawal of forest resources may be recognized. Concessions on state-owned lands are included here.

- Category 2 - Designated for Indigenous Peoples and Local Communities: National law recognizes Indigenous Peoples' and local communities' rights to access and withdrawal, as well as 
to participate in the management of forests or to exclude outsiders. Other tenure rights may also be recognized, but the bundle of legally recognized rights held by communities does not amount to "forest ownership" as defined under Category 3.

- Category 3 - Owned by Indigenous Peoples and Local Communities: Forestlands are owned by Indigenous Peoples and local communities where their forest rights of access, withdrawal, management, exclusion, and due process and compensation are legally recognized for an unlimited duration. Alienation rights (whether through sale, lease, or use as collateral) are not required for communities to be classified as forest owners under this framework.

- Category 4 - Privately Owned by Individuals and Firms: Individuals and firms are considered to privately own forestland when they legally hold the full bundle of rights described under Category 3 (access, withdrawal, management, exclusion, and due process and compensation) for an unlimited duration, as well as the right to sell their forestland.

In addition to presenting forest area data under these four categories, this analysis sought to further disaggregate private forest ownership under Category 4 into two sub-categories: (1) private forests owned by individual and family smallholders (including family-owned businesses), and (2) remaining private forests owned by firms (excluding small ownerships of family-owned businesses), legal persons, and individuals and families with medium and large holdings. Box 1 presents the limited disaggregated data available, in addition to legal, policy, and administrative definitions of "smallholder forest ownership" collected over the course of this analysis.

\section{Figure 1}

\section{SPECTRUM OF THE BUNDLE OF RIGHTS}

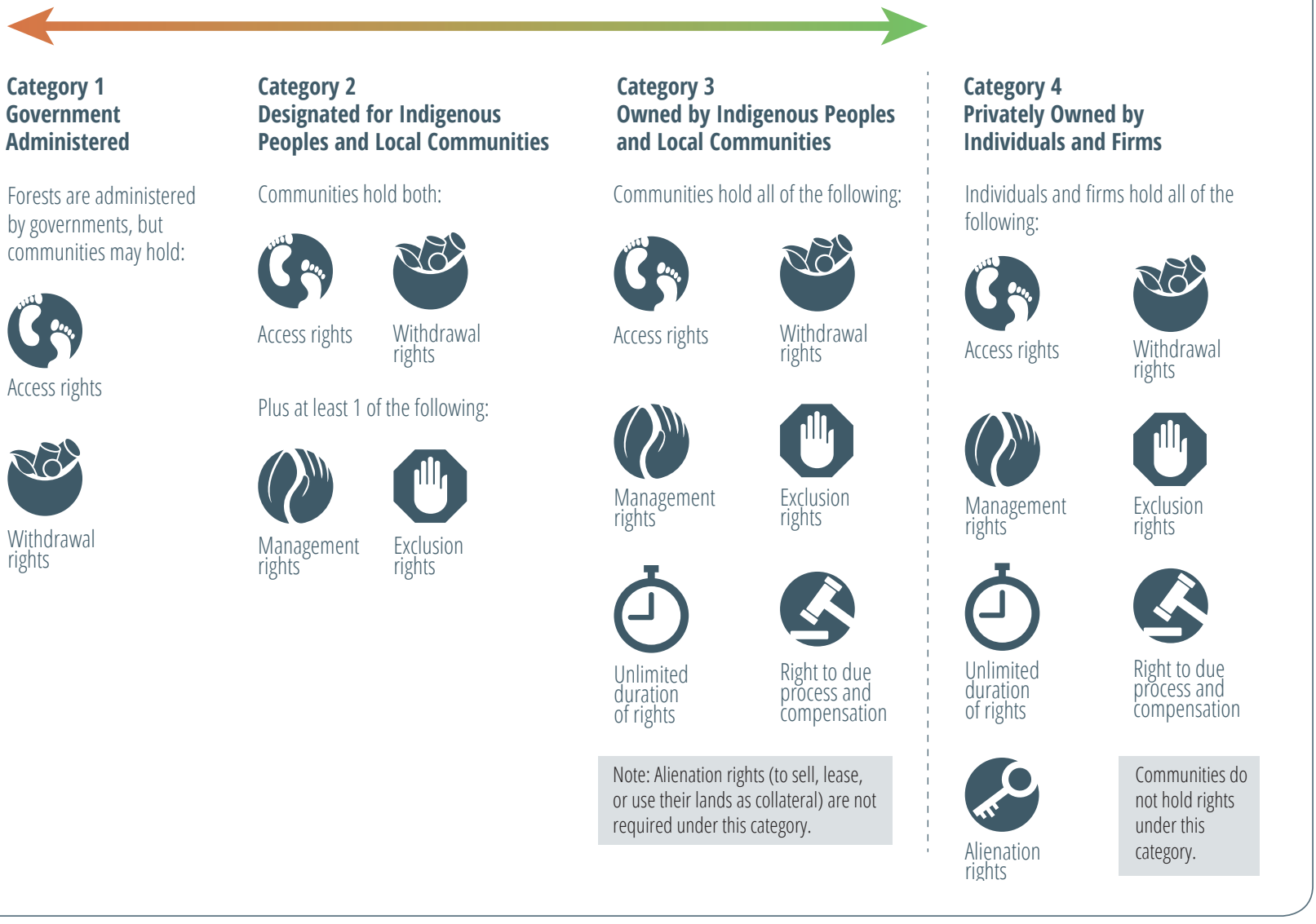




\subsection{Scope}

RRI's forest tenure data was last published in What Future for Reform? Progress and Slowdown in Forest Tenure Reform Since 2002 (2014), which analyzes the distribution of forest tenure in 52 countries. This report presents available data for 58 countries (including the 52 countries featured in the 2014 publication), cumulatively containing nearly 92 percent of global forest area. . $^{x}$ Of the 58 countries analyzed, 48 are low- and middle-income countries (LMICS) and 10 are high-income countries (HICs).

Six countries were added to RRI's global data set for the first time in 2017: Chile, Ecuador, Mali, Mongolia, Panama, and Senegal. RRI first published data on Indigenous Peoples' and local communities' legally recognized forest tenure rights in Mali, Panama, and Senegalwith a focus on the tenure rights of women within those communities-in the 2017 publication Power and Potential: A Comparative Analysis of National Laws and Regulations concerning Women's Rights to Community Forests. ${ }^{\times}$Data on the distribution of forest ownership within these three countries was collected in 2017 to enable comparison across RRI's quantitative and legal data sets. Chile and Panama are Forest Carbon Partnership Facility (FCPF) Participant Countries, and Chile, Ecuador, and Mongolia are UN-REDD Partners.

\section{Global findings and trends}

\subsection{Global status of forest tenure across 58 countries as of 2017}

Table 1 presents data on the distribution of forest area across the four categories of statutory forest tenure described in Section 1.1 within 58 countries, including the world's 30 most forested countries. ${ }^{\text {xi }}$ Among the 58 countries featured in this analysis, available data in 17 countries is either incomplete across all years or insufficiently detailed to disaggregate among the four forest tenure categories described in Section 1.1. As a result, it is necessary to distinguish between countries with a full data set-termed "complete case countries" throughout this report-and countries where only partial data exists. The reasons for incomplete country data sets vary. Ongoing conflict has prevented the collection of forest tenure data in some countries, while in others it is not methodologically possible to reconcile available data with RRI's statutory forest tenure typology. To ensure methodological consistency, all discussion of trends in forest tenure over time in this report rely solely on analysis of complete case countries identified in 2017.

As of 2017, Indigenous Peoples and local communities are legally recognized as owning at least 447 million hectares (mha), or 12.2 percent, of forestland within the 58 countries analyzed. In addition, they have legally designated rights to over 80 mha (2.2 percent) of global forest area. By comparison, individuals and firms privately own no less than 419 mha (11.4 percent) of global forest area (excluding areas under concessionary or licensing agreements), and governments legally claim administrative authority over more than two-thirds of global forest area $(2,482 \mathrm{mha})$. xi

When considering the 19 African countries, 18 Asian countries, and 16 Latin American countries included in this analysis, Latin America contains the greatest proportion of forest area both legally owned by and designated for Indigenous Peoples and local communities, followed by Asia, and then Africa. While available tenure data accounts for more than 90 percent of Latin America's forests and nearly 97 percent of forests in Asia, available tenure data covers less than 77 percent of Africa's forests. The lower coverage of forest tenure data for Africa is largely due to a lack of comprehensive data in Kenya, Mali, and Mozambique, where 


\section{Table 1}

STATUTORY FOREST TENURE ACROSS 58 COUNTRIES, 2002-2017 (MHA)

\begin{tabular}{|c|c|c|c|c|c|c|c|c|}
\hline \multirow[b]{2}{*}{ Country } & \multicolumn{2}{|c|}{$\begin{array}{l}\text { Government } \\
\text { Administered }\end{array}$} & \multicolumn{2}{|c|}{$\begin{array}{l}\text { Designated for } \\
\text { Indigenous Peoples and } \\
\text { Local Communities }\end{array}$} & \multicolumn{2}{|c|}{$\begin{array}{l}\text { Owned by Indigenous } \\
\text { Peoples and Local } \\
\text { Communities }\end{array}$} & \multicolumn{2}{|c|}{$\begin{array}{l}\text { Privately Owned by } \\
\text { Individuals and Firms }\end{array}$} \\
\hline & 2002 & 2017 & 2002 & 2017 & 2002 & 2017 & 2002 & 2017 \\
\hline Angola $^{1}$ & $59.73^{2}$ & $57.86^{3}$ & - & - & - & $0.001^{4}$ & - & - \\
\hline Argentina & $5.70^{5}$ & n.d. & n.d. & $0.87^{6}$ & - & - & $22.20^{7}$ & n.d. \\
\hline Australia & $93.96^{8}$ & $83.30^{9}$ & $0.00^{10}$ & $9.10^{11}$ & $20.87^{12}$ & $12.11^{13}$ & $14.01^{14}$ & $20.24^{15}$ \\
\hline Belize $^{16}$ & n.d. & n.d. & n.d. & - & - & n.d. & n.d. & n.d. \\
\hline Bhutan & $2.60^{17}$ & $2.65^{18}$ & $0.001^{19}$ & $0.08^{20}$ & - & - & $0.004^{21}$ & $0.001^{22}$ \\
\hline Bolivia & $41.43^{23}$ & $28.03^{24}$ & $1.58^{25}$ & $0.47^{26}$ & $16.61^{27}$ & $24.71^{28}$ & $0.48^{29}$ & $1.55^{30}$ \\
\hline Brazil & $341.02^{31}$ & $238.39^{32}$ & $10.68^{33}$ & $40.41^{34}$ & $75.27^{35}$ & $118.05^{36}$ & $94.29^{37}$ & $99.89^{38}$ \\
\hline Cambodia & $11.16^{39}$ & $7.73^{40}$ & 0.00 & $0.46^{41}$ & 0.00 & $0.00^{42}$ & - & - \\
\hline Cameroon & $22.12^{43}$ & $18.98^{44}$ & 0.00 & $3.02^{45}$ & - & - & $0.00^{46}$ & $0.00^{47}$ \\
\hline Canada ${ }^{48}$ & $319.32^{49}$ & $318.34^{50}$ & $0.20^{51}$ & $0.30^{52}$ & $6.60^{53}$ & $6.81^{54}$ & $21.68^{55}$ & $21.62^{56}$ \\
\hline $\begin{array}{l}\text { Central African } \\
\text { Republic }\end{array}$ & $22.40^{57}$ & $22.17^{58}$ & - & $0.00^{59}$ & - & - & 0.00 & $0.002^{60}$ \\
\hline Chile & n.d. & $5.49^{61}$ & n.d. & n.d. & n.d. & $0.86^{62}$ & n.d. & $11.32^{63}$ \\
\hline China & $76.06^{64}$ & $75.20^{65}$ & - & - & $103.06^{66}$ & $124.30^{67}$ & - & - \\
\hline Colombia & $38.00^{68}$ & $26.38^{69}$ & - & - & $24.50^{70}$ & $32.93^{71}$ & - & - \\
\hline Costa Rica & $1.11^{72}$ & $1.10^{73}$ & - & - & $0.34^{74}$ & $0.28^{75}$ & $1.32^{76}$ & $1.06^{77}$ \\
\hline $\begin{array}{l}\text { Democratic } \\
\text { Republic of the Congo }\end{array}$ & $157.25^{78}$ & $152.41^{79}$ & - & $0.17^{80}$ & - & - & - & - \\
\hline Ecuador $^{81}$ & n.d. & n.d. & - & $0.02^{82}$ & - & $1.27^{83}$ & n.d. & n.d. \\
\hline Ethiopia & $13.70^{84}$ & $12.29^{85}$ & $0.01^{86}$ & $0.21^{87}$ & - & - & - & - \\
\hline Finland & $10.09^{88}$ & $10.41^{89}$ & - & - & $0.12^{90}$ & $0.12^{91}$ & $16.10^{92}$ & $15.67^{93}$ \\
\hline Gabon & $22.00^{94}$ & $22.93^{95}$ & 0.00 & $0.07^{96}$ & - & - & - & - \\
\hline Gambia & $0.44^{97}$ & $0.44^{98}$ & $0.02^{99}$ & $0.05^{100}$ & - & - & $0.001^{101}$ & $0.001^{102}$ \\
\hline Guatemala & $1.85^{103}$ & n.d. & $0.53^{104}$ & $0.40^{105}$ & $0.29^{106}$ & $1.20^{107}$ & $1.53^{108}$ & n.d. \\
\hline Guyana & $16.62^{109}$ & $13.17^{110}$ & - & $3.35^{111}$ & - & - & 0.00 & $0.00^{112}$ \\
\hline Honduras & $4.07^{113}$ & $1.18^{114}$ & - & $0.60^{115}$ & $0.00^{116}$ & $1.79^{117}$ & $1.36^{118}$ & $1.80^{119}$ \\
\hline India & $56.02^{120}$ & $59.28^{121}$ & -122 & - & - & $1.11^{123}$ & $9.37^{124}$ & $9.77^{125}$ \\
\hline Indonesia'126 & $97.69^{127}$ & $85.36^{128}$ & $0.22^{129}$ & $0.79^{130}$ & - & $0.01^{131}$ & $1.49^{132}$ & $4.86^{133}$ \\
\hline Japan & $10.43^{134}$ & $11.06^{135}$ & - & - & $1.05^{136}$ & $0.28^{137}$ & $13.39^{138}$ & $13.09^{139}$ \\
\hline Kenya & $3.48^{140}$ & n.d. & - & $0.38^{141}$ & - & n.d. ${ }^{142}$ & $0.08^{143}$ & $0.09^{144}$ \\
\hline Korea, Republic of & $1.89^{145}$ & $2.08^{146}$ & $0.03^{147}$ & $0.005^{148}$ & - & - & $4.50^{149}$ & $4.25^{150}$ \\
\hline Lao PDR & $16.53^{151}$ & $18.74^{152}$ & - & $0.02^{153}$ & - & - & $0.00^{154}$ & $0.00^{155}$ \\
\hline Liberia & n.d. & n.d. & - & n.d. & - & $0.58^{156}$ & n.d. & n.d. \\
\hline Malaysia'157 & - & - & - & - & - & - & - & - \\
\hline Mali158 & n.d. & n.d. & $0.00^{159}$ & $0.00^{160}$ & n.d. & n.d. & $0.004^{161}$ & $0.004^{162}$ \\
\hline Mexico ${ }^{163}$ & 2.75 & 3.65 & - & - & 44.00 & 45.47 & 8.30 & 16.92 \\
\hline Mongolia & $12.89^{164}$ & $8.94^{165}$ & - & $3.35^{166}$ & - & - & - & - \\
\hline Mozambique $^{167}$ & n.d. & n.d. & n.d. & $0.07^{168}$ & n.d. & n.d. & - & - \\
\hline Myanmar & $34.23^{169}$ & $28.88^{170}$ & $0.02^{171}$ & $0.16^{172}$ & - & - & - & - \\
\hline Nepal & $4.63^{173}$ & $4.54^{174}$ & $1.02^{175}$ & $2.07^{176}$ & - & - & $0.002^{177}$ & $0.002^{178}$ \\
\hline Nigeria $^{179}$ & $12.97^{180}$ & - & $0.16^{181}$ & n.d. & - & - & - & - \\
\hline
\end{tabular}




\section{Table 1, continued}

\begin{tabular}{|c|c|c|c|c|c|c|c|c|}
\hline \multirow[b]{2}{*}{ Country } & \multicolumn{2}{|c|}{$\begin{array}{l}\text { Government } \\
\text { Administered }\end{array}$} & \multicolumn{2}{|c|}{$\begin{array}{l}\text { Designated for } \\
\text { Indigenous Peoples and } \\
\text { Local Communities }\end{array}$} & \multicolumn{2}{|c|}{$\begin{array}{l}\text { Owned by Indigenous } \\
\text { Peoples and Local } \\
\text { Communities }\end{array}$} & \multicolumn{2}{|c|}{$\begin{array}{l}\text { Privately Owned by } \\
\text { Individuals and Firms }\end{array}$} \\
\hline & 2002 & 2017 & 2002 & 2017 & 2002 & 2017 & 2002 & 2017 \\
\hline Panama & $3.92^{182}$ & $3.63^{183}$ & n.d. & n.d. & $0.90^{184}$ & $0.90^{185}$ & $0.04^{186}$ & $0.08^{187}$ \\
\hline Papua New Guinea & $0.90^{188}$ & $0.84^{189}$ & - & - & $29.20^{190}$ & $27.01^{191}$ & $0.03^{192}$ & $0.03^{193}$ \\
\hline Peru & $58.77^{194}$ & $54.38^{195}$ & $1.57^{196}$ & $4.98^{197}$ & $10.52^{198}$ & $12.78^{199}$ & $5.29^{200}$ & $0.12^{201}$ \\
\hline Philippines ${ }^{202}$ & $13.84^{203}$ & $9.46^{204}$ & $1.97^{205}$ & $1.64^{206}$ & $0.04^{207}$ & $4.71^{208}$ & - & - \\
\hline Republic of the Congo & $22.56^{209}$ & $22.33^{210}$ & $0.00^{211}$ & $0.00^{212}$ & - & - & $0.00^{213}$ & $0.00^{214}$ \\
\hline Russia 215 & 809.27 & 814.93 & 0.00 & 0.00 & 0.00 & 0.00 & - & - \\
\hline Senegal & $8.89^{216}$ & $8.26^{217}$ & $0.004^{218}$ & -219 & - & - & $0.002^{220}$ & $0.01^{221}$ \\
\hline South Sudan'222 & - & n.d. & - & n.d. & - & n.d. & - & $0.00^{223}$ \\
\hline Sudan 224 & n.d. & n.d. & $0.04^{225}$ & $0.20^{226}$ & n.d. & n.d. & n.d. & n.d. \\
\hline Suriname & $15.30^{227}$ & $15.11^{228}$ & - & - & - & - & $0.09^{229}$ & $0.09^{230}$ \\
\hline Sweden 231 & $6.86^{232}$ & $7.25^{233}$ & - & $0.19^{234}$ & $0.54^{235}$ & $0.70^{236}$ & $20.77^{237}$ & $19.94^{238}$ \\
\hline Tanzania 239 & $35.13^{240}$ & $17.29^{241}$ & $0.07^{242}$ & $5.39^{243}$ & $16.60^{244}$ & $21.91^{245}$ & $0.12^{246}$ & $3.51^{247}$ \\
\hline Thailand & $17.01^{248}$ & $15.87^{249}$ & - & $0.48^{250}$ & - & - & $0.00^{251}$ & $0.00^{252}$ \\
\hline Timor-Leste ${ }^{253}$ & n.d. & n.d. & n.d. & n.d. & n.d. & n.d. & n.d. & n.d. \\
\hline Togo & $0.13^{254}$ & $0.06^{255}$ & - & - & - & n.d. ${ }^{256}$ & $0.35^{257}$ & n.d. ${ }^{258}$ \\
\hline United States & $129.16^{259}$ & $129.97^{260}$ & - & - & $7.33^{261}$ & $7.52^{262}$ & $166.59^{263}$ & $172.59^{264}$ \\
\hline Venezuela & $49.15^{265}$ & n.d. & 0.00 & n.d. ${ }^{266}$ & - & - & - & - \\
\hline Vietnam & $11.78^{267}$ & $13.25^{268}$ & .269 & $1.13^{270}$ & - & - & - & - \\
\hline Zambia & $51.13^{271}$ & $48.54^{272}$ & - & $0.08^{273}$ & - & $0.02^{274}$ & - & 0.00 \\
\hline $\begin{array}{l}\text { TOTAL } \\
\text { (41 Complete Case } \\
\text { Countries) }\end{array}$ & 2670.74 & 2472.97 & 17.41 & 78.56 & 356.64 & 442.62 & 379.18 & 407.02 \\
\hline $\begin{array}{l}\text { TOTAL } \\
\text { (All } 58 \text { Countries) }\end{array}$ & 2747.95 & 2482.15 & 18.15 & 80.50 & 357.84 & 447.43 & 403.39 & 418.50 \\
\hline
\end{tabular}

Highlighting in gray indicates Complete Case Countries

Dashes (-) denote situations in which the tenure category in question is not legally possible under national law.

n.d. = No Data

national laws broadly recognize the customary ownership of Indigenous Peoples and local communities without requiring communities to register their forests and other lands. ${ }^{\text {xii }}$ Given the prevalence of customary land tenure in all three countries, a substantial portion of the combined 47 mha of forestland across Kenya, Mali, and Mozambique would likely be attributed to Category 3 (owned by Indigenous Peoples and local communities) if such area data were available. .iv $^{\text {in }}$

Across the 48 LMICS assessed_representing over 93 percent of LMIC forests globally__Indigenous Peoples and local communities legally own at least $418 \mathrm{mha}$ (15.2 percent) of forestland and at least $70 \mathrm{mha}$ (2.5 percent) of forestland are designated for Indigenous Peoples and local communities. More than two-thirds of LMIC forests, representing at least 1,911 mha, are formally administered by governments, and at least 140 mha (5.1 percent) are privately owned by individuals and firms.

\subsection{Global trends in forest tenure across 41 complete case countries, 2002-2017}

Because complete data across all four tenure categories and/or years is unavailable for 17 of the 58 countries presented in Table 1, forest tenure as of 2017 is unknown for approximately 6.49 percent of the total forest area among all 58 countries included in this analysis. ${ }^{x i}$ As discussed in Section 2.1, countries with incomplete data are thus excluded from the below analysis of trends over time to ensure consistency across the data set. 


\section{Figure 3}

\section{GLOBAL STATUS OF STATUTORY FOREST TENURE IN 58 COUNTRIES AS OF 2017 BY PERCENT}

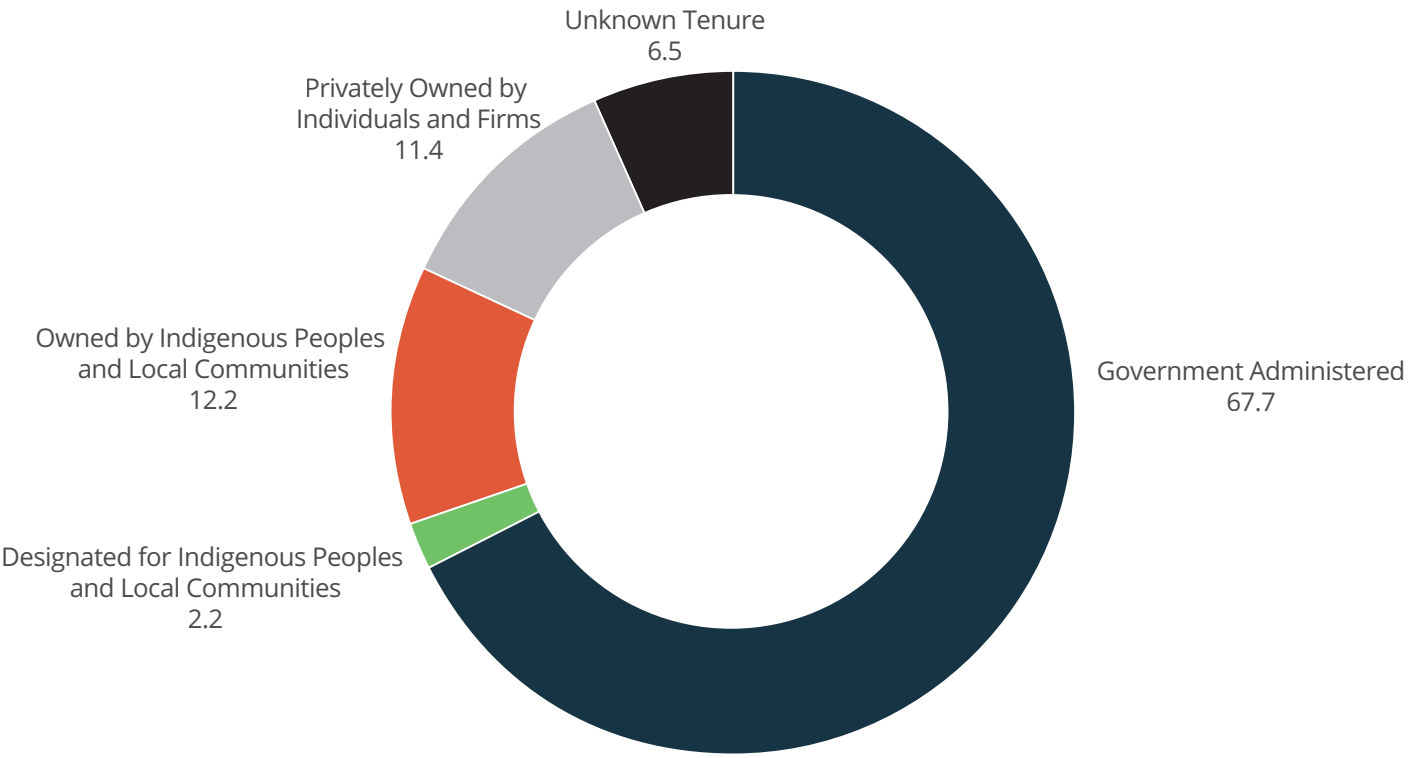

\section{Figure 4}

GLOBAL CHANGE IN STATUTORY FOREST TENURE IN 41 COMPLETE CASE COUNTRIES BY PERCENT, 2002-2017

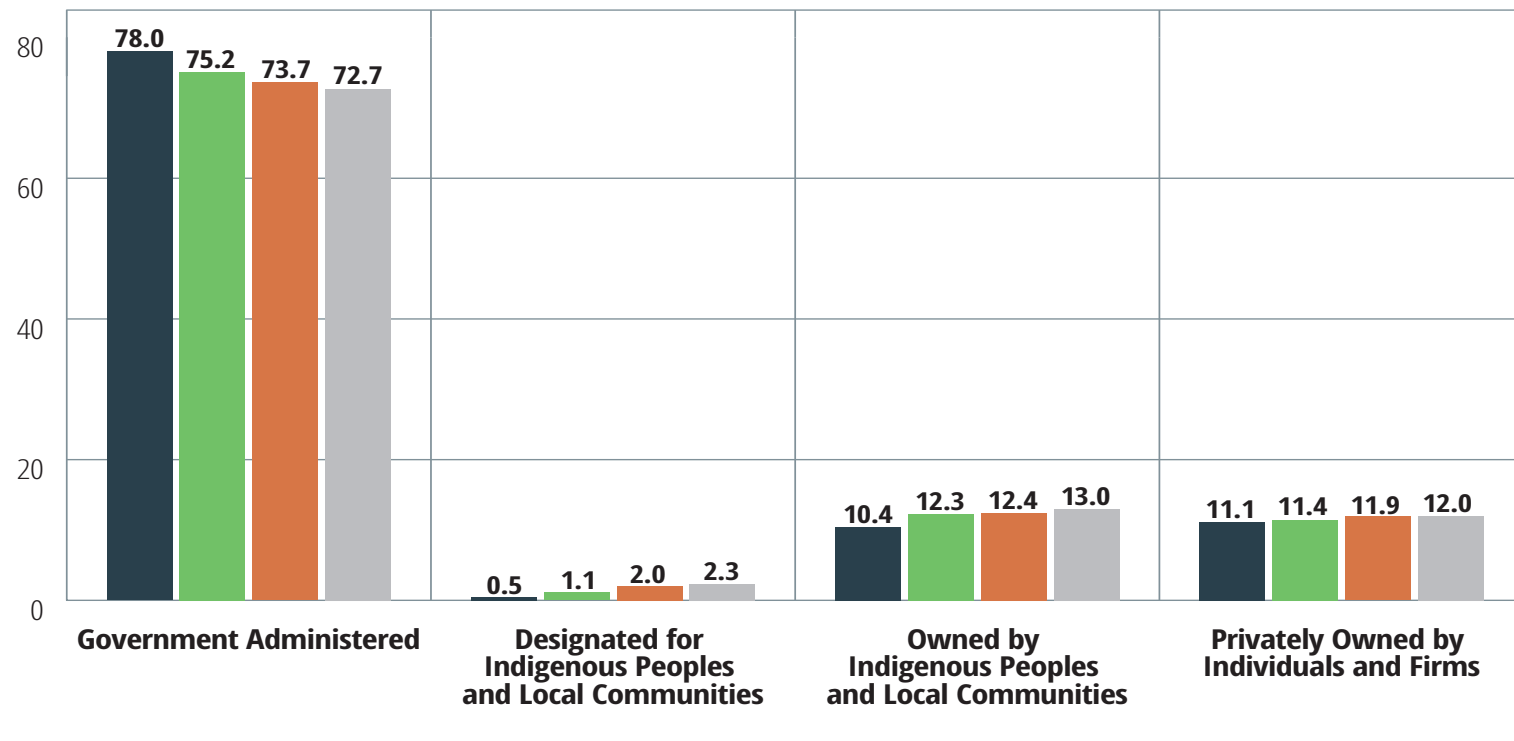

$2002 \quad 2008 \square 2013 \square 2017$

Note: Due to rounding, percents shown across all four statutory forest tenure categories for a given year do not all sum to 100\% 
Among the 41 countries for which complete data was available for 2002 and 2017 (hereafter referred to as "complete case countries"), data indicates the following key trends:

While significant gains in the legal recognition of Indigenous Peoples and local communities as forest owners and designated rightsholders have been made over the past 15 years, the pace of recognition has generally remained slow since 2008, despite a very slight uptick since RRI last reported on the distribution of forest tenure in 2013. As of 2017, 15.3 percent ( $521 \mathrm{mha}$ ) of forests across the 41 complete case countries assessed are cumulatively designated for and owned by Indigenous Peoples and local communities.

The total forest area owned by and designated for Indigenous Peoples and local communities
increased by 147 mha over the previous 15 years (from 374 mha in 2002 to 521 mha in
2017); however, nearly 60 percent ( 87 mha) of these areas were recognized during the 2002-
2008 period. Within the same 41 countries, just under 33 mha of forests were recognized
as designated for and owned by Indigenous Peoples and local communities during the five
years between 2008-2013, and less than 28 mha of additional forests were recognized
under community tenure in the four years since 2013 . The overall slowdown in recognition of
community-based forest tenure between $2002-2017$ appears to be approaching a plateau,
despite the fact that much of the forest area claimed by Indigenous Peoples and local
communities remains to be legally recognized.

Just under three-quarters (30) of the 41 countries with complete data experienced an overall increase in forest area recognized as designated for and owned by Indigenous Peoples and local communities over the 2002-2017 period. ${ }^{\text {xvi }}$ However, just over half (21) of these 41 countries saw an increase in forestland cumulatively designated for and owned by Indigenous Peoples and local communities since 2013. xviii

Encouragingly, the rate of increase in forest area owned by Indigenous Peoples and local communities over the four years from 2013-2017 exceeded that observed over the previous five-year period (2008-2013)-possibly signaling an emerging increase in the legal recognition of community forest ownership. The recognition of forests designated for Indigenous Peoples and local communities since 2013 was markedly lower than recognition during the 2002-2008 and 2008-2013 periods.

Between 2013-2017, there was a notable shift in the strength of community tenure recognized by governments. Whereas 93.7 percent of community forests recognized between 20082013 within these 41 countries (almost 31 mha out of the nearly 33 mha recognized as both designated for and owned by communities) constituted mere "designation" rights falling short of ownership, the pendulum has swung in favor of community ownership since 2013. Of the nearly 28 mha of community forests (both owned by and designated for communities) recognized during the 2013-2017 period, almost two-thirds (18 mha) are recognized as owned by Indigenous Peoples and local communities. In the context of increasing global demand for land and resources, and the urgent need to protect forest carbon sinks while meeting the needs of the rural poor, this is a positive trend that ought to be supported by all possible means.

Governments continue to maintain legal and administrative authority over more than 70 percent of forestlands $(2,473 \mathrm{mha})$, much of which is claimed by Indigenous Peoples and local communities.

Forestland administered by governments decreased by 198 mha between 2002-2017, with the rate of decline slowing over this period. While government administered forestland decreased by an average of 16 mha per year between 2002 and 2008, the average decrease per year since 2008 has been approximately 10 mha. The area of government administered forestland now comprises 2,473 mha (or 72.7 percent of total forest area across 41 countries).

Much of the 2,473 mha of government administered forest is contested by indigenous and local communities who assert ownership over these forests as territories that they customarily hold, manage, and depend on for their survival. Despite the vast areas under dispute, a large proportion of government administered forest is either managed as protected areas or locked in state-issued concessions, licensing agreements, or untapped resource claims held for the benefit of private companies, local elites, or other investors. Trends in the establishment of new concessions are divergent-with some countries scaling up their forest concession regimes while others are reducing or even prohibiting such activities ${ }^{\mathrm{xix}}$-yet across all regions companies acquire concessions with markedly greater ease and speed than 
communities, ${ }^{x x}$ often leaving enduring impacts and permanently transforming forest landscapes. Furthermore, companies' concession agreements seldom recognize communities as parties to the agreement whose rights will be impacted by the concession and who are therefore entitled to direct benefits under the agreement. Area data on forest concessions is difficult to access due to a lack of transparency concerning concession agreements, but a forthcoming RRI analysis found that as of 2017, timber extraction and logging contracts to corporate entities cover at least 41 mha of government administered forest in Brazil, Cameroon, DRC, Indonesia, and Liberia. xxi

Given the negligible decrease in government administered forests since 2002-and the fact that even this modest rate of decline is diminishing as time progresses_communities' welldocumented conflicts on government administered forests with both governments and private entities are likely to endure in the absence of significant gains in the recognition of communitybased tenure.

Private forest ownership by individuals and firms (excluding concessions) remained relatively constant over the fifteen-year period, increasing from 11.1 percent (380 mha) in 2002 to 12.0 percent (407 mha) in 2017. However, a lack of up-to-date and transparent data concerning the status, size, and owners of private forest holdings hampers the ability to discern trends with respect to privately owned forests.

Data representing the status of private forest ownership as of 2014 or later years exists for 12 of the 29 complete case countries where private forest ownership is legally possible. ${ }^{\text {xxi }}$ Within these 12 countries, 6 countriesxiii saw an increase in private forest ownership since 2014, while 5 countries ${ }^{x i v}$ saw a decline in private forest ownership over the same period. The most notable change in private forest area is in Tanzania, where private forest ownership increased from 0.17 mha (0.4 percent of Tanzania's total forest area) in 2013 to 3.5 mha (7.3 percent of Tanzania's total forest area) in 2017.

For the first time, this analysis also sought to further disaggregate forest area data under Category 4 by quantifying the forest area specifically owned by individual and family smallholders (including family-owned businesses) in accordance with the definitions identified in national laws, regulations, and other governmentissued documents. The limited legal and area-based data available on smallholder forest ownership within the countries included in this analysis is presented in Box 1. Because forest area data disaggregating individual and family smallholdings from the more substantial forest ownerships is largely unavailable, this analysis cannot assess the extent to which the 407 mha of private forest area is formally held by smallholders-whose socioeconomic status and interests may be similar to those of Indigenous Peoples and local communities-versus private corporations and local elites, whose objectives concerning forest ownership commonly diverge from those of communities.

\subsection{Trends in 33 complete case LMICs in Africa, Asia, and Latin America}

Of the $147 \mathrm{mha}$ of forests legally recognized as both designated for and owned by Indigenous Peoples and local communities among 41 complete case countries between 2002-2017, nearly all of this area was gained within 33 low- and middle-income countries (LMICs) across Africa, Asia, and Latin America containing just over $\mathbf{5 8}$ percent of forest area in LMICs globally. Only an additional 400,000 hectares were recognized within HICs with complete data over the same period. From 2013-2017, almost 94 percent of forests recognized as owned by communities across all 41 complete case countries occurred in LMICS.

The percent of forest area cumulatively designated for and owned by Indigenous Peoples and local communities in these 33 countries rose from 19.3 percent (337 mha) in 2002 to 24.3 percent (425 mha) in 2008 but increased more moderately thereafter, amounting to 26.4 percent of total LMIC forest area (458 mha) in 2013 and 28.1 percent (484 mha) in 2017. Among the three regions assessed in this report, Latin America has recognized the largest forest area as designated for and owned by Indigenous Peoples and local communities, comprising nearly 60 percent of the total community forest area legally recognized across the 33 LMICs with complete data as of 2017. Seven out of nine complete case Latin American countries (excluding Guyana and Suriname) have legal frameworks recognizing community-based forest ownership, as compared to 5 of 13 complete case countries in Asia and 3 of 12 complete case countries in Africa.

Between 2013 and 2017, the forest area legally owned by Indigenous Peoples and local communities within LMICs in Africa, Asia, and Latin America increased by almost 17 mha, from $398 \mathrm{mha}$ (23.0 percent of total forest area in 33 countries) to $415 \mathrm{mha}$ (24.1 percent of total forest area in 33 countries), thus outpacing the nearly 11 mha increase in community forest ownership 


\section{CRITICAL AND CONSEQUENTIAL DATA GAPS ON SMALLHOLDER FOREST OWNERSHIP}

No singular global definition of "smallholder forest ownership" exists, but in its broadest conception "smallholder forestry" comprises a growinga and important ${ }^{\mathrm{b}}$ subset of forest-holding communities, individuals, families, and local (often family-owned) small businesses. To increase the visibility of data on locally managed forests under both collective and individual tenure systems, this analysis sought to disaggregate RRI's data on forests privately owned by individuals and firms (Category 4) into two subcategories: (1) private forests owned by individual and family smallholders (including family-owned businesses); and (2) remaining private forests owned by firms (excluding small ownerships of family-owned businesses), legal persons, and individuals and families with medium and large holdings. Private forest owners under both subcategories possess legally recognized, individually-based forest rights for an unlimited duration, including the right of sale. Because national definitions of "small forest ownerships" depend on a range of country-specific considerations (i.e., forest area, population density, forest use patterns, and natural resource availability), smallholder forest area was determined by using country-specific legal, policy, and administrative definitions of "smallholder forest ownership" or analogous terms. This textbox highlights the main findings of RRI's foray into this critical subset of key actors in the management of forests worldwide.

\section{Few countries define "smallholder forest ownership," and even fewer have corresponding area data.}

Despite their tremendous importance for the realization of global climate goals and the SDGs, few countries legally define smallholder forest ownership, and fewer still have quantified the total area of these small-scale forest holdings. Forty-two of the 58 countries featured in this analysis legally permit individuals and/or firms to privately own forests, but only 9 (21 percent) of these (Argentina, Bhutan, Bolivia, Brazil, Canada, Chile, Costa Rica, Mexico, and Sweden) formally define "smallholder forest ownership" or an analogous term that can be used as a proxy to identify small-forest ownerships. Six of these are in Latin America (as compared to one Asian country and no African countries), reflecting, in part, the extent to which Latin American countries legally allow individuals and firms to own forests in comparison to African and Asian countries. Interestingly, most of the countries that formally define "smallholder forest ownership" are LMICS.

Data on the extent of smallholder forest ownership was only identified in Argentina, Canada, Chile, and Mexico (see Table 2, below), all of which are either HICs (Argentina, Canada, and Chile) or upper middle-income countries (Mexico). This data pertains to small forests privately owned by individuals, families, and firms; disaggregated data on smallholder ownership of family-owned businesses does not exist. Of these, Canada and Chile are the only countries for which the available smallholder area even approaches comprehensive coverage. Argentina and Mexico report but a subset of the total estimated smallholder forest area under individual tenure.c

Existing legal definitions of smallholder forest ownership demonstrate considerable diversity with respect to who qualifies as a smallholder and shed light on countries' assumptions concerning the purpose of small-scale forestry. Some countries employ definitions emphasizing smallholders' dependence on forests for subsistence (Bolivia) and livelihood (Chile) purposes. Canada and Sweden include minimum areas for small forest holdings in their definitions ( 25 and 5 hectares respectively), possibly to distinguish between commercial and non-commercial forest holdings. Among the eight countries (excluding Bolivia) that formally limit the size of smallholder ownerships, limits range widely from approximately 10 hectares (Argentina and Bhutan) to 100,000 hectares ("private woodlots" in New Brunswick, Canada), with defined limits varying based on location within both Canada and Chile.

Rightsholders are also identified differently across jurisdictions. Chile is the only country whose definition includes indigenous or local communities as smallholders. Ownership is limited to individuals and families in Bhutan, Bolivia, and Brazil; smallholders in Costa Rica are defined as farmers engaged in forestry activities; and Canada, Chile, and Sweden specifically exclude holdings by some medium and large businesses. 


\section{Box 1, continued}

\section{Gaps in the legal recognition and documentation of smallholder forest ownership impact the decisions of key stakeholders with respect to national economic development, global climate priorities, and the achievement of the SDGs.}

The undefined status of "smallholder forest ownership" hampers governments' ability to distinguish small forests owned and managed by individuals, families, and family-owned businesses from those of medium- and largeholders. This legislative ambiguity is part of a more central problem of countries' laws failing to account for critical differences in how these groups manage and use forests. Such legal oversights can result in unreasonable regulatory demands on small-scale forest owners that place access to financing and the establishment of formal businesses outside their reach, thus compelling some smallholders to operate illegally. ${ }^{\text {d }}$

The dearth of reliable data also limits the ability of stakeholders to make informed decisions in favor of smallscale forestry. In the absence of legal definitions of smallholders: (1) local forest managers' rights to use, market, and sell land, timber, and non-timber forest products are largely unaccounted for, undervalued, and oftentimes hampered by prevailing economic and regulatory measures; and (2) it becomes difficult to assess the area of forestland used by different producer groups (including women, families, small local enterprises, and communities), producers' associated market-share, and their contributions to rural economies and sustainable forest management. Correspondingly, these critical policy and data gaps restrict the ability of governments and international finance institutions to adequately support smallholders.

Table 2: Formal definitions and available area of "smallholder forest ownership" in 9 countries as of 2017

\begin{tabular}{|c|c|c|}
\hline Country & $\begin{array}{l}\text { Key elements of legal, policy, and administrative definitions of "small } \\
\text { forest owner" or proxy term }\end{array}$ & $\begin{array}{l}\text { Smallholder forest area (mha) (rightsholders } \\
\text { specified) }\end{array}$ \\
\hline Argentina & $\begin{array}{l}\text { "Small Producers": Individuals and other legal persons with forest areas under } 10 \mathrm{ha} \text {, as } \\
\text { defined by Ministry of Agriculture, Livestock, and Fisheries. }\end{array}$ & $\begin{array}{l}0.000050027 \text { (Individual and legal person "small } \\
\text { producers" engaged in plantation forestry or native forest } \\
\text { enrichment, who received support under the government's } \\
\text { Forest Production Direction program) }\end{array}$ \\
\hline Bhutan & $\begin{array}{l}2007 \text { Land Act of Bhutan limits most family land holdings to } 25 \text { acres (approximately } 10 \\
\text { ha).g }\end{array}$ & Not available \\
\hline Bolivia & $\begin{array}{l}\text { A "small property" is the source of subsistence resources for an owner and his family." } \\
\text { Under the Constitution and agrarian law, it is a family asset that cannot be divided or } \\
\text { judicially seized.' A "small property" is not subject to agrarian property taxes.! }\end{array}$ & Not available \\
\hline Brazil & $\begin{array}{l}\text { Small property and rural family ownership: Family-exploited forests not over 30, 50, or } \\
150 \text { ha depending on location. }\end{array}$ & Not available \\
\hline Canada & $\begin{array}{l}\text { - Forest owners with at least } 25 \text { ha are eligible for tax incentives under British } \\
\text { Colombia's Private Forest Land Act (2003)! } \\
\text { "Private woodlots" are defined by the New Brunswick Forest Products Act (2012) to } \\
\text { exclude ownerships of: over } 100,000 \text { ha; the Crown; and persons who principally } \\
\text { operate wood processing facilities that do not mainly produce wood chips at harvest } \\
\text { sites." } \\
\text { - A National Resource Canada report defines "woodlot owners" outside British } \\
\text { Colombia as "non-industrial private forests"." }\end{array}$ & $\begin{array}{l}18.67 \text { (Data pertains to forests of individuals, families, } \\
\text { and firms - excepting some large businesses excluded by } \\
\text { formal definitions - reported by various cited sources) }\end{array}$ \\
\hline Chile & $\begin{array}{l}\text { A "small forest owner": (1) Holds title to at least one forest property, plegally qualifies as } \\
\text { is "small agricultural producer,"“ and directly works their forest or a third party's,' and } \\
\text { (2) mainly derives income from agricultural and forestry exploitation.s Such ownerships: } \\
\text { (1) may not exceed } 12 \text { ha of basic irrigation or area established by zone;" (2) may not } \\
\text { exceed 200, } 500 \text {, or } 800 \text { ha, depending on location;", and (3) in specified regions, owners' } \\
\text { activities may not exceed 3,500 development units." }\end{array}$ & $\begin{array}{l}0.00104436 \text { (Data pertains to "small forest owners" as } \\
\text { defined by Decreto Ley No. } 701 \text { de 1974, which includes } \\
\text { persons, rainfed societies, and companies with at least } \\
60 \% \text { of capital shares held by the original forest owner(s), } \\
\text { and specified indigenous and agricultural communities)" }\end{array}$ \\
\hline Costa Rica & $\begin{array}{l}\text { "Small forest producers": Farm owners engaged in annual forest protection, management, } \\
\text { reforestation, or regeneration, where farms are } 50 \text { ha or less, or where agroforestry } \\
\text { systems are comprised of 5,000 trees or less.” }\end{array}$ & Not available \\
\hline Mexico & "Small forest property": Any kind of forest ownership of 800 ha or less.y & $\begin{array}{l}.950280 \text { (Small, individually owned private property } \\
\text { subject to logging management plans; identity of } \\
\text { rightsholder not specified) }{ }^{2}\end{array}$ \\
\hline Sweden & $\begin{array}{l}\text { "Small-scale forestry": Non-large-scale forestry units (thus excluding large forests defined } \\
\text { as those of about 5,000 ha, or forest businesses with at least } 10 \text { forestry employees) of at } \\
\text { least } 5 \text { ha.a }\end{array}$ & Not available $e^{\text {bb }}$ \\
\hline
\end{tabular}




\section{Figure 5}

CHANGE IN STATUTORY FOREST TENURE IN 33 COMPLETE CASE LMICS BY PERCENT, 2002-2017

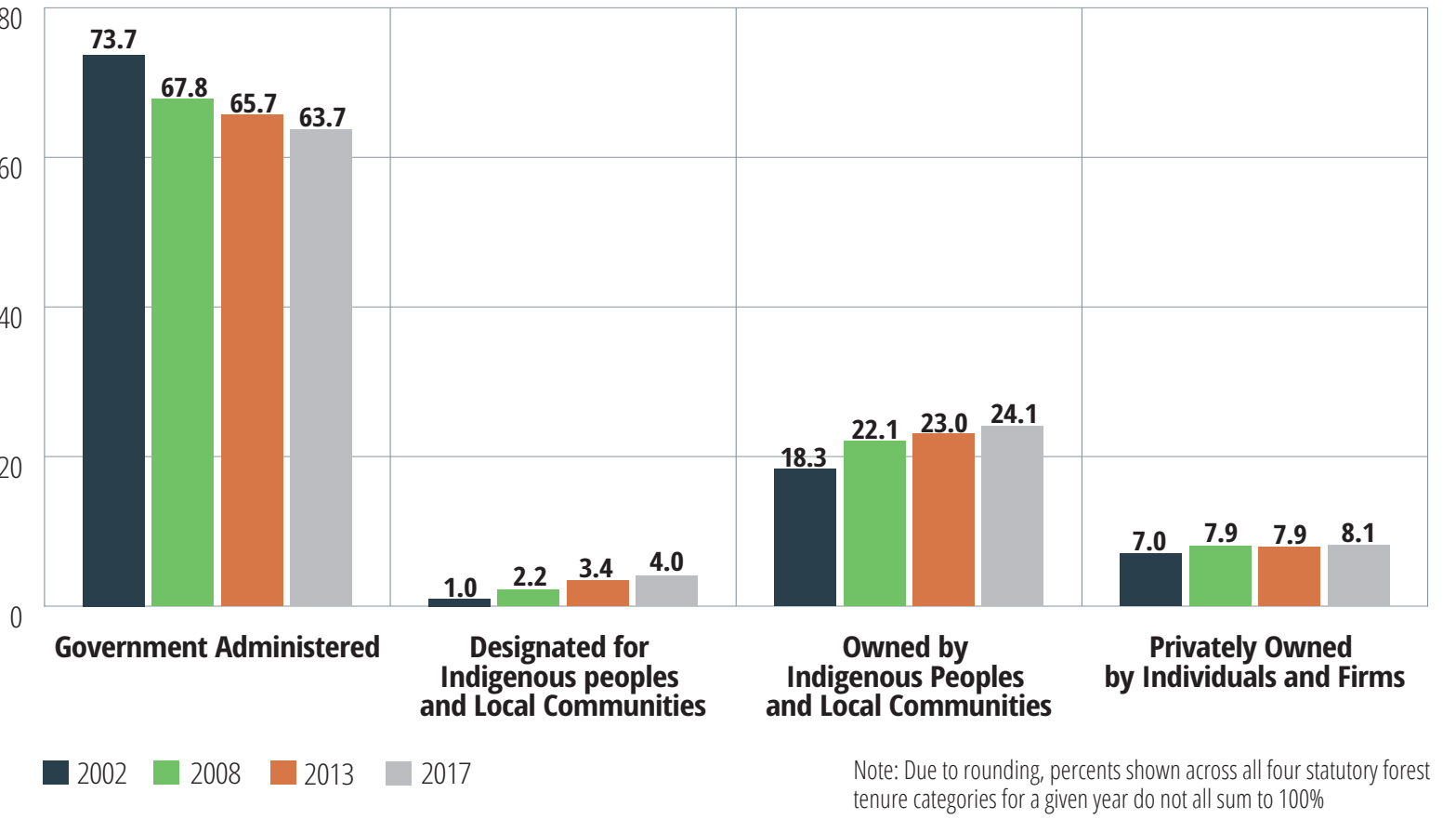

noted in the previous five-year period (2008-2013). When compared to government designation of community forests-which increased by less than 10 mha since 2013-this signals a potential upswing in LMIC recognition of Indigenous Peoples and local communities as forest owners.

\section{Regional trends across 33 complete case LMICs in Africa, Asia, and Latin America}

\subsection{Africa}

Angola, Cameroon, Central African Republic, Democratic Republic of the Congo, Ethiopia, Gabon, Gambia, Republic of the Congo, Senegal, Tanzania, Zambia

The recognition of communities' forest rights in Africa continues to lag behind progress made in Asia and Latin America, despite positive steps by some countries to legally recognize communitybased tenure. As of 2017, less than 31 mha (7.4 percent) of forests are designated for and owned by communities within the 11 complete case countries assessed. The forest area owned by communities comprises 22 mha, or 5.2 percent, of the total forest area in these 11 countries. Angola, Tanzania, and Zambia are the only complete case countries in Africa with legal frameworks recognizing Indigenous Peoples and/or local communities as forest owners. In Tanzania, the forest area owned by communities through Village Land Forest Reserves, Non-Reserved Forests on Village Lands, Community Forest Reserves, and Wildlife Management Areas has increased from 17 mha (32.0 percent of Tanzania's forest area) in 2002 to 22 mha (45.6 percent of Tanzania's forest area) in 2017. xxv Nearly 16,000 hectares of community forest have recently been recognized under Zambia's 2015 Forests Act, representing the only forests to be legally owned by communities under Zambian national law. In Angola, the area recognized as owned by communities continues to be less than 1,000 hectares. xxvi Notably, the forest area under Category 3 (owned by Indigenous Peoples and local communities) in Africa would undoubtedly be higher if widely accepted and forestspecific data on the significant areas legally owned by communities in Kenya, Mali, and Mozambique-three countries with laws broadly recognizing the customary forest ownership of communities without requiring any formal registration of these rights—was available. 


\section{Figure 6}

REGIONAL TRENDS ACROSS COMPLETE CASE LMICS BY PERCENT, 2002-2017

2002
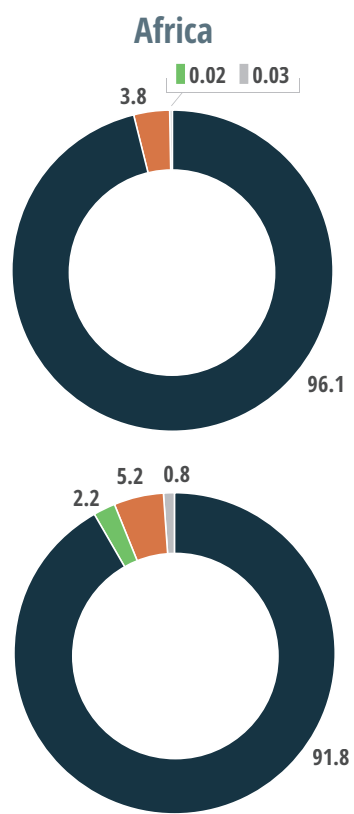

Asia
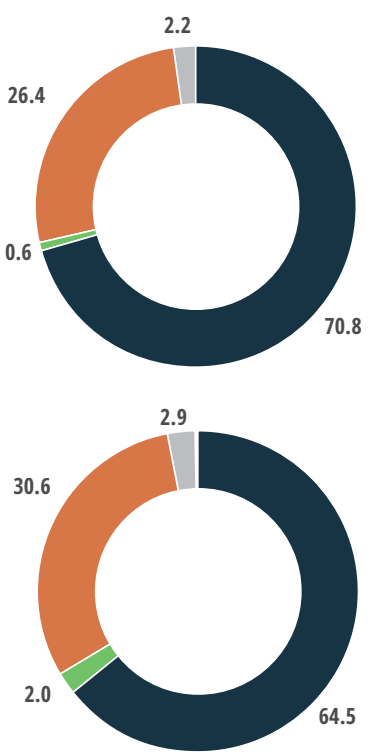

Latin America

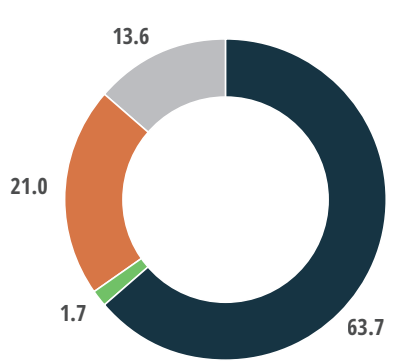

29.9

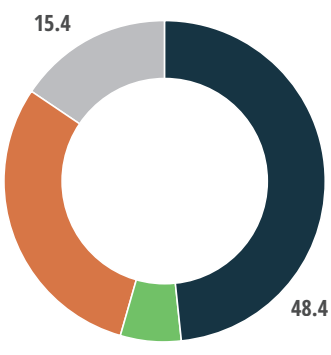

6.3

Government Administered

Designated for Indigenous Peoples and Local Communities

Owned by Indigenous Peoples and Local Communities

Privately Owned by Individuals and Firms

The forest area designated for communities within the 11 complete case countries in Africa increased by nearly 9 mha over the 15-year period, but progress since 2013 has been marginal. Whereas 5 mha of forestland was designated for communities between 2008 and 2013, only an additional 0.9 mha of forestland was designated for communities since 2013. Furthermore, Gambia and Senegal both saw a decrease in the forest area designated for communities since 2013. In Gambia, this decrease is attributed to an expansion in agricultural production that reportedly reduced forest area within community forests. ${ }^{\text {xvvii }}$ In Senegal, the passing of a new decentralization law in 2013 transferred forest management authority from the community level to the municipal township level, xxviii thus precluding the only existing legal avenue by which forests were previously designated for communities under Senegalese national law.

\subsection{Asia}

Bhutan, Cambodia, China, India, Indonesia, Lao PDR, Mongolia, Myanmar, Nepal, Papua New Guinea, Philippines, Thailand, Vietnam

The rate of statutory forest tenure recognition for Indigenous Peoples and local communities has progressed modestly across Asia over the last 15 years, with China accounting for most of the gains achieved. Since 2002, the area owned by Indigenous Peoples and local communities across 13 complete case countries in Asia increased by just under 25 mha. However, over 85 percent (21 mha) of gains in community forest ownership over this period are attributable to increased recognition of collective forests in China.

Outside of China, progress across the remaining 12 complete case countries in Asia has been even more limited, with the forest area designated for and owned by Indigenous Peoples and local communities increasing only 11 mha over the 15-year period from 32 mha (10.1 percent) to 43 mha (13.7 percent). Only 4 of these 12 countries (India, Indonesia, Papua New Guinea, and the Philippines) possess legal frameworks recognizing communities as forest owners. After China, Papua New Guinea has the next largest forest area (27 mha) under customary ownership, but recent estimates indicate that 12 percent of tribal land areas 
remain under State Agricultural Business Leases (SABLS) issued to third parties for a 99-year period, after which leased forests and other lands revert to communities.

xxix India, Indonesia, and the Philippines each exhibited an increase of less than 1 mha in community forest ownership since 2013. Given that the potential for recognition of Scheduled Tribes and Other Traditional Forest Dwellers' rights under the Forest Rights Act in India and of customary $\left(\right.$ Adat $^{\mathrm{x} x}$ ) forest in Indonesia collectively exceed $80 \mathrm{mha}$, xxxi the current rate of recognition is unacceptably low.

Within the 13 complete case countries in Asia, forest area designated for Indigenous Peoples and local communities increased from $3 \mathrm{mha}$ (0.6 percent) to $10 \mathrm{mha}$ (2.0 percent) during the 2002-2017 period, with an increase of nearly $3 \mathrm{mha}$ since 2013. Ten of these 13 countries (excluding China, India, and Papua New Guinea, which all have legal frameworks recognizing Indigenous Peoples and local communities as forest owners) have legal frameworks designating forests for Indigenous Peoples and local communities. The most notable increase occurred in Mongolia, where over $1 \mathrm{mha}$ of forest have been recognized for community forest user groups since 2013. Finally, legislative advancements in Myanmar since 2013 have set the stage for future progress. The 2016 revision to the Community Forest Instruction expands community rights under Community Forest Concessions to include livelihood development and commercial rights that could incentivize the establishment of new Community Forest Concessions, thus resulting in additional forest area designated for Indigenous Peoples and local communities.

\subsection{Latin America}

Bolivia, Brazil, Colombia, Costa Rica, Guyana, Honduras, Mexico, Peru, Suriname

\begin{abstract}
Within the nine complete case countries in Latin America, the rate of Indigenous Peoples' and local communities' recognition as forest owners increased markedly between 2013-2017 as compared to the previous five-year period (2008-2013). Forest area owned by Indigenous Peoples and local communities increased from 171 mha (21 percent) in 2002 to 236 mha (29.9 percent) in 2017. Indigenous Peoples and local communities acquired legal recognition for the vast majority of these areas prior to 2008; progress slowed drastically between 2008 and 2013, with less than a 5 mha cumulative increase across Bolivia, Brazil, Colombia, Honduras, and Peru. Since 2013, Indigenous Peoples and local communities have gained ownership over an additional $11 \mathrm{mha}$ of forestland. This is due to a $7 \mathrm{mha}$ increase in Indigenous Lands and Quilombola Territories in Brazil, 3 mha increase in Indigenous Reserves and Afro-Colombian Community Lands in Colombia, and nearly $1 \mathrm{mha}$ in titles granted to the Miskitu communities in Honduras over the past four years.
\end{abstract}

Within the same nine Latin American countries, forest area designated for Indigenous Peoples and local communities increased from $14 \mathrm{mha}$ (1.7 percent) in 2002 to $50 \mathrm{mha}$ (6.3 percent) in 2017. The increase of just under 6 mha in forest area designated for Indigenous Peoples and local communities since 2013 is attributed to increases in Brazil, Guyana, Honduras, and Peru. $x x x i i$

The proportion of private forest area within the complete case LMICs in Latin America as of 2017 (15.4 percent) far exceeds that of the other regions, with a proportion five times larger than that found across Asian complete case countries (2.9 percent), and 17 times larger than the proportion of private forest area found in African complete case countries (0.9 percent). This wide variance is attributed —in part-to the higher proportion of countries in Latin America that legally allow forests to be privately owned by individuals and firms (8 out of 9 complete case countries in Latin America, as compared to 7 out of 13 complete case countries in Asia and 7 out of 11 complete case countries in Africa). Best available data indicates that 15.4 percent (just over $121 \mathrm{mha}$ ) of total forest area across the nine complete case Latin American countries is 


\section{Figure 7}

RRI TARGETS AND TRENDS IN TENURE RECOGNITION IN 33 LMICS, 2002-2017

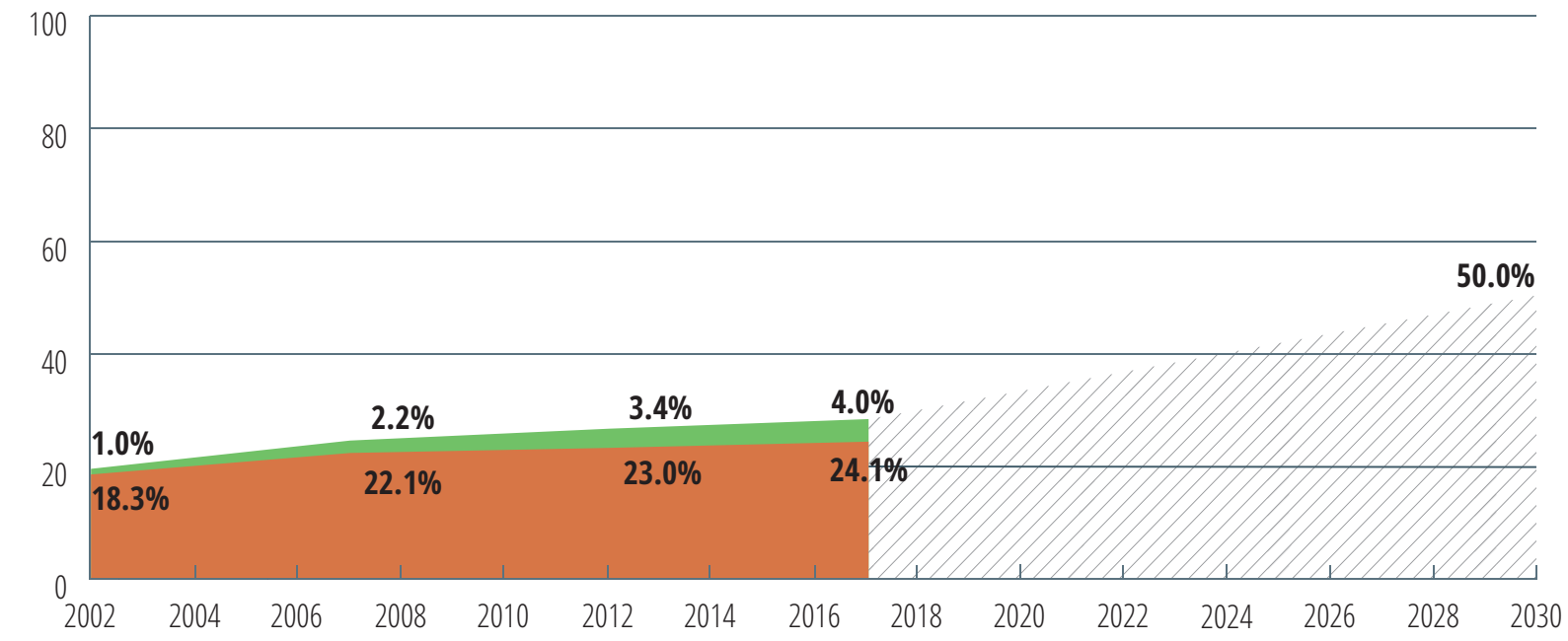

*. Goal Owned by or Designated for Indigenous Peoples and Local Communities

Designated for Indigenous Peoples and Local Communities

Owned by Indigenous Peoples and Local Communities

privately owned by firms and individuals as of 2017, but trends in private forest ownership since 2013 are especially elusive in Latin America due to a lack of up-to-date data. Honduras is the only complete case country in Latin America where updated data on private forest ownership was identified since 2013.

\section{Progress toward RRI and global targets}

At its founding in 2005, RRI set a target for the global community to double the forest area designated for and owned by Indigenous Peoples and local communities by 2015. While the world fell short of this goal, the SDGs and the Paris Agreement offer a renewed opportunity to call upon national governments to scale up tenure security for Indigenous Peoples, local communities, and rural women that is paralleled by RRI's new global goal to see at least 50 percent of the total forest area in LMICs legally owned by and designated for Indigenous Peoples and local communities by 2030. As Figure 5 illustrates, governments must nearly double the recognized area of community-based forest tenure by 2030 in order for this new target to be achieved. Data from 33 LMICS across Africa, Asia, and Latin America indicates that just over 28 percent of forest area (484 mha) was legally owned by and designated for Indigenous Peoples and local communities as of 2017. Assuming forest area remains constant within LMICs, achieving this goal would require these 33 countries to collectively recognize at least $\mathbf{2 2}$ mha of forest-equivalent to more than half of California's land areaxxiii_-per year as owned by or designated for Indigenous Peoples and local communities, essentially requiring the rate of recognition over the 2013-2017 period to more than triple between 2017-2030.

Accelerating recognition of Indigenous Peoples' and local communities' forest tenure is critical for achieving global commitments such as those enshrined in the SDGs, the Paris Agreement, the Voluntary Guidelines on the Responsible Governance of Tenure of Land, Fisheries and Forests in the Context of National Food Security (VGGT), the Bonn Challenge, the NYDF, and the Aichi Biodiversity Targets. SDG Indicators 1.4.2 (on the proportion of the adult population with secure land tenure) and 5.a.2 (on women's equal rights to own and/or control land) urge countries to advance the legal recognition, documentation, and tenure security of Indigenous Peoples, local communities, rural women, and smallholders. ${ }^{\text {xxxiv }}$ The 2020 Aichi Biodiversity Targets established under the Convention on Biodiversity intend to draw on SDG Indicators 1.4.2 and 5.a.1 
in order to report on "Trends in land-use change and land tenure in the traditional territories of indigenous and local communities." ${ }^{\prime \prime x x v}$

The global community is also rapidly approaching key 2020 and 2030 milestones for halting deforestation and restoring forestlands. The Bonn Challenge-bolstered by the NYDF-has secured commitments by 47 national governments, sub-national governments and programs, and companies to restore over 160 mha of deforested and degraded land by 2030. ${ }^{x x x i}$ The restoration of forest landscapes necessitates careful contemplation concerning who will maintain rights to own and administer these spaces, ensuring that Indigenous Peoples, local communities, and rural women are both respected partners in and beneficiaries of these efforts. These principles are furthered by the NYDF Goals-particularly "Goal 10: Strengthen forest governance, transparency and the rule of law, while also empowering communities and recognizing the rights of indigenous peoples, especially those pertaining to their lands and resources"which have been endorsed by an overlapping yet distinct set of more than 190 governments, multinational companies, and civil society and Indigenous Peoples' organizations. ${ }^{\text {xxvii }}$

\section{Pervasive challenges amidst emerging opportunities}

Promising developments have occurred in the first half of 2018. In DRC, 27 new Local Community Forest Concessions covering at least 56,149 ha have been recognized as designated for communities as of July 2018. xxxviii Between March 2017 and February 2018, an additional 561,139 ha of forest were recognized as designated for Indigenous Peoples and local communities in Indonesia, including 395,216 ha of Hutan Desa (Village Forest), 138,117 ha of Hutan Kemasyarakatan (Rural or Community Forest), and 27,806 ha of Hutan Tanaman Rakyat (People Plantation Forest)..xxix In February 2018, the Quilombola community of Cachoeira Porteira in Brazil received title to more than 220,000 ha of forest. The issuance of these titles follows the Brazilian Supreme Court's February 2018 rejection of a suit aimed at rendering Presidential Decree 4.887/2003 invalid and drastically limiting existing legal pathways for titling Quilombola territories. Instead, the court affirmed the constitutionality of the decree-thus supporting the efforts of more than 1,600 Quilombola communities in the process of titling their territories. ${ }^{.1}$ Notably, in April 2018 Mexico passed the General Law on Sustainable Forest Development, xi a fundamental piece of legislation whose implementation will impact the security of Ejidos and Comunidades for years to come.

\section{Concerning legislative rollbacks and stalled reform processes threaten to undermine the} progress observed at the global level. In both Indonesia and the Philippines, once promising reforms have failed to deliver expected gains. In Indonesia, President Joko Widodo's issuance of Hutan Adat certificates of customary forest ownership in December 2016 and October 2017 cumulatively resulted in the recognition of Indigenous Peoples' customary ownership over 8,801 hectares of customary forests. ${ }^{\text {lii }}$ These developments represent the Indonesian government's first implementation of the landmark 2013 Constitutional Court Ruling No. 35/2013 (more commonly known as MK35), which dramatically strengthened Indigenous Peoples' legally recognized tenure rights by removing their traditionally managed customary forests (Hutan Adat) from state control and mandating the formalization of Indigenous Peoples' ownership over these customary forests for the first time. Yet, Indigenous Peoples' ownership rights to the vast majority of their customary Adat forests and other lands_estimated to comprise approximately 40 mhaxilii_has yet to be formalized through the certification process required by the Constitutional Court decision. Also concerning is that the size of Adat forest areas recognized in 2017 were far smaller than the areas that received certificates of customary forest ownership in 2016.

The rate of recognition of Certificates of Ancestral Domain Titles (CADTs) in the Philippines has also slowed significantly in comparison to previous periods. Between 2012 and 2015, just over 387,000 ha of CADTs were recognized, whereas over 705,000 ha were recognized during the previous three-year period (2009-2012), and more than 2,500,000 ha were recognized between 2006 and 2009. xliv This notable decline in recognition of ancestral domains comes amid a dramatic rise in the targeted killing and criminalization of land and environmental defenders under President Rodrigo Duterte's administration. Forty-eight land and environmental defenders were murdered in 2017, more than 40 percent of whom were protesting agribusiness. ${ }^{x v}$

Successful implementation of Colombia's 2016 peace agreement is intertwined with the advancement of the comprehensive agrarian reform process called for by the Accord, including the recognition of the collective land rights of Indigenous Peoples and Afro-descendant communities. An analysis conducted in 2017 found that 271 Afro-descendant communities have applied for collective land titles, some of whom have awaited formal recognition of their lands for two decades. Available georeferenced data for just 147 of those claims indicates that at least 1 million hectares of land are claimed by Afro-descendant communities.xivi 


\section{EVICTIONS AND VIOLENCE AGAINST FOREST COMMUNITIES PERSIST IN THE NAME OF CONSERVATION}

Mounting evidence demonstrates that Indigenous Peoples and local communities achieve conservation outcomes that are equivalent or superior to government-funded "fortress models" premised on communities' eviction from protected areas, yet communities continue to suffer mass evictions, violence, and other human rights abuses perpetrated by governments in the name of forest conservation.dd

Only months after the African Court on Human and Peoples' Rights refuted the Kenyan Government's argument that forest conservation necessitated the eviction of the Ogiek from their ancestral lands in Kenya's Mau Forest Complex, ${ }^{\text {ee }}$ the forest-dwelling Sengwer peoples in western Kenya experienced a fresh wave of conservation-driven, government-imposed forced evictions (including house burnings and violence) from their ancestral territories in the Embobut Forest.ff The January 2018 killing of Sengwer community member Robert Kirotich by the Kenya Forestry Service during an associated Embobut Forest raid led the EU to suspend its 31 million Euro funding of an environmental program intended to conserve high-elevation forests in areas including the Embobut Forest and Mt. Elgon, which Kenya depends on for much of its water supply.gs Despite the EU's response and a recent Kenyan National Commission on Human Rights report documenting multiple violations of the Sengwer peoples' land rights, hi the future of the Sengwer's longstanding battle to assert their rights remains uncertain.

Similar injustices have taken place in Liberia, where communities' rights to over 20,000 hectares of forestland were violated due to the 2017 gazettement of the Gola and Grebo-Krahn National Parks. Green Advocates and other Liberian civil society organizations describe the establishment of these parks as a violation of the Community Rights Law of 2009_one that appears indistinguishable from land grabs commonly perpetuated against communities by large multinational corporations in Liberia. Impacted communities contend that these parks were established through unjust and inadequate assessment and consultation processes that violated their right to free, prior, and informed consent, resulting in their coerced consent to the parks' establishment."

The struggles of many Karen communities in Thailand demonstrate the inter-generational impacts of conservation-driven evictions. One example is of Karen communities who have been embroiled in conflict concerning the Kaeng Krachan forest since the 1981 establishment of Kaeng Krachan National Park. In 2011, park officials accompanied by armed Thai military forcibly evicted Karen villagers from their lands, burned their homes and rice stores, and imprisoned 106-year old Grandpa Kor-ee. Kor-ee's grandson-a leader and human rights defender of the Ban-bang-kloy Karen Peoples known as "Billy"served as a witness in the 2012 case instituted by those Karen communities to secure the return of their lands, but Billy disappeared under suspicious circumstances in 2014 and his whereabouts have yet to be determined.j. In June 2018, Thailand's Supreme Court granted those Karen communities compensation for the 2011 eviction but denied their right to return home. For almost 40 years, the Karen have sought justice through a legal system that fails to recognize their citizenship and status as Indigenous Peoples, enduring irreparable harm in the name of conservation that cannot be compensated. ${ }^{k} k$

As these examples demonstrate, protected areas established through the eviction of Indigenous Peoples and local communities - the population oftentimes best-positioned and most motivated to protect forests and forest resources_commonly generate long-standing conflict, violate communities' free, prior, and informed consent alongside other human rights, and overlook the true drivers of forest loss and degradation. 
Legislative setbacks have also taken place since 2013, in some cases resulting in large-scale forest

grabs. Law No. 30723 of Peru, enacted in January 2018, declares the construction and maintenance of roads in the border regions of Ucayali to be a national priority. Despite the law's call to uphold "unrestricted respect for natural protected areas and the Indigenous Peoples who inhabit it," highway construction has the potential to open the traditional territories of Indigenous Peoples in voluntary isolation and initial contact situations to increased deforestation, displacement, and conflict. xvii With evidence that 95 percent of deforestation throughout the Amazon occurs within 5.5 kilometers of a roadway or 1 kilometer of a navigable river, xviii it is probable that additional roadways will significantly increase threats to these communities.

Furthermore, as previously discussed in Section 3.1, Senegal's new decentralization law fails to extend essential forest management rights to local communities. xlix Liberia's 2009 Community Rights Law (CRL) widely recognizes customary communities as the lawful owners of the forestlands they hold under customary law, without requiring any forestland registration procedure, yet the new 2017 CRL Regulation attempts to rescind these broadly recognized rights, stipulating that only "authorized forest communities" with state-signed community forest management agreements may access, use, manage, and benefit from their forest resources.! The Regulation explicitly claims to set aside questions of forest ownership while harshly narrowing communities' rights over forest resources and mandating cumbersome procedures that communities must fulfill in order to legally secure meaningful tenure.

\section{At a crossroads: A call to action}

\section{Progress in the recognition of community-based forest tenure remains inadequate to meet international commitments on climate and development.}

Unless governments move quickly and decisively to legally recognize and secure the community forests of Indigenous Peoples and local communities, the world is unlikely to meet pressing sustainable development and climate goals. To achieve progress, governments must work in collaboration with Indigenous Peoples, local communities, rural women, civil society, the private sector, and the broader international community to take full advantage of the following opportunities:

1. Proactively seize opportunities offered by new legislation to enable the realization of communities' forest tenure rights.

Legislation establishing new legal pathways for Indigenous Peoples' and local communities' forest ownership over the last four years further supports the global trend toward recognition of communities as forest owners. This is especially notable in Africa, where legislation in Kenya, Mali, and Zambia establishes new legal frameworks for community forest ownership. If fully implemented, the Community Land Act (2016) in Kenya, the Agricultural Land Law (Loi No. 2017-001, du 11 Avril 2017 portant sur le foncière agricole) in Mali, and the 2015 Forests Act in Zambia could result in the realization of secure community forest rights for Indigenous Peoples and local communities at a grand scale, as the majority of these countries' rural lands are held under customary tenure. The new laws in both Kenya and Mali provide communities with an avenue to register their recognized customary rights to community forests and other lands for the first time, without requiring registration for communities' rights to become actionable. Given the gender-specificity found in the Community Land Act, the rights of indigenous and rural women stand to be particularly strengthened in Kenya. However, the ability of the new laws in Kenya, Mali, and Zambia to effectively benefit Indigenous Peoples, local communities, and rural women will be strongly influenced by implementing regulations that, as of 2017, had yet to pass.

2. Support and hold governments accountable in their obligations to comply with national and international court rulings and binding legal precedents.

In addition to advocating for legislative avenues that advance community-based tenure, Indigenous Peoples and other forest communities have successfully sought recognition of their collective tenure rights through national constitutional courts as well as regional human rights courts like the InterAmerican Court of Human Rights. Noteworthy judgments in Latin America and Africa since 2013 include: the May 2017 African Court on Human and Peoples' Rights (ACHPR) judgment concerning the Ogiek in Kenya's Mau Forest; the 2015 Inter-American Court of Human Rights judgment Kaliña and Lokono Peoples v. Suriname; and the 2015 Caribbean Court of Justice judgment Maya Leaders Alliance v. The Attorney General of Belize."i 
These holdings find that governments are legally obligated to recognize community-plaintiffs as Indigenous Peoples, and to legally recognize their tenure rights through legislation forged via communities' full, effective, and informed consultation. In both the Ogiek and Suriname cases, governments' conservation-motivated actions-either through the eviction of communities from degraded forests or the establishment of national nature reserves on community forests-were found to be inadequate justifications for violating communities' rights to their territories, particularly given the role of Indigenous Peoples in successfully conserving their lands and natural resources.

Despite the strength of these holdings, their enforcement by national governments remains lacking. The Caribbean Court of Justice serves as the highest court of appeals in Belize, and Suriname is a ratifying party to the Inter-American Convention on Human Rights, yet neither government has legally recognized the tenure rights of the communities who served as plaintiffs in the cases referenced above. At the time of this report's authorship the ACHPR had yet to issue a reparations order in relation to the Mau Ogiek case, but Kenya need not wait on this order to respect the full extent of the rights recognized by the May 2017 ACHPR judgment. Kenya can and should set a positive example by restoring all 416,542 square hectares (22 forest blocks) of Mau Forest Complex that comprise the Mau Ogiek's ancestral lands to the Ogiek, ceasing evictions of other Ogiek communities outside of the Mau Forest Complex, lii and extending the rights recognized in the Ogiek decision to other Indigenous Peoples (including the Sengwer, as discussed in Box 3) throughout Kenya.

3. Bolster communities' existing tenure rights and expand Indigenous Peoples' and local communities' forest ownership in draft legislation on forest, land, and community rights.

At the time of writing, RRI is aware of draft legislation pending in Ecuador, Kenya, Lao PDR, Nepal, and Thailand. Multiple reforms are underway in Lao PDR, where a new Land Policy was issued in August 2017 and the Land Law, Forest Law, and associated by-laws are currently undergoing revision, according to the Emissions Reductions Program Document (ER-PD) submitted to the Forest Carbon Partnership Facility (FCPF) Carbon Fund in March 2018. liii

4. Harness the momentum of the SDGs, Paris Agreement, the VGGT, and other emerging tools and platforms to monitor and report on the forests owned and managed by Indigenous Peoples, local communities, rural women, and smallholders.

The world has never been better positioned to drastically scale up tenure recognition through the utilization of targeted technologies and financing instruments, and to increase data collection that lends visibility to the status of Indigenous Peoples', local communities', rural women's, and smallholders' land and forest tenure. In particular, custodian agencies responsible for monitoring progress toward the SDGs should continue to further nuance data collection efforts to ensure that circumstances surrounding community-based tenure are comprehensively measured. More fundamentally, governments must make a concerted effort to collect data effectively capturing the particular challenges to tenure security faced by rural women, those who rely on communitybased tenure, and other small-scale forest owners. In all circumstances, collected data should be disaggregated by gender.

A central limitation of analyses on local forest management is most governments' failure to define "smallholder forest ownership" and to collect corresponding area data demonstrating the proportion of forests privately owned by individual and family smallholders (including family-owned businesses) versus those owned by medium and large forest holders. The general lack of "smallholder forest ownership" definitions is symptomatic of governments' larger failure to devise laws tailored to the circumstances of local forest managers, which negatively impacts both communities and individual/ family smallholders alike. It is therefore imperative that governments address these critical legislative failures, which should include the generation of context-specific definitions of "smallholder forest ownership" and corresponding data on the extent of these ownerships. This would enable more robust assessment of the world's privately-owned forests and associated implications for Indigenous Peoples and local communities. Such data would also facilitate information exchange, comparisons, and learning, which may identify new opportunities for partnerships and convergent points of advocacy among Indigenous Peoples, local communities, rural women, and smallholders. Finally, it is imperative that both governments and private entities increase transparency regarding the size, parties, and terms surrounding their forest concession agreements.

Heightened emphasis on robust, nuanced, and appropriately disaggregated data collection is critical for monitoring progress toward national and global climate, economic, and development goals, and stakeholders must work together in ensuring that necessary data is collected and made available to 
track the world's progress.

The world currently stands at a crossroads before two drastically divergent futures. Over the coming years, government progress in the recognition of community-based tenure could stagnate, preventing the world from achieving key development and climate milestones. Alternatively, governments can choose a more prosperous future by devoting the additional time and political capital necessary to rapidly accelerate the recognition of Indigenous Peoples and local communities as full forest owners. A choice in favor of this second alternative is one that places forests in the hands of the Indigenous Peoples, local communities, and rural women who are best-situated to steward them. It prioritizes countries' rural economic development by safeguarding communities' cultural and economic interests, and it gives the world its best chance of combatting climate change. Pursuing the path toward a more just, environmentally sound, and prosperous future requires urgent, concerted action. It will not be easy, and governments cannot embark upon this journey alone. However, with the support of Indigenous Peoples, local communities, rural women, community forest champions, civil society, the private sector, and the larger international community, a brighter future is within our collective reach. 


\section{Annex: Technical notes}

\section{Underlying Data on "Total Forest Area" by Country}

RRI largely relies on forest area data submitted by national governments to the FAO as input to the Global Forest Resources Assessment, which is published every five years. However, RRI may instead utilize alternate data concerning countries' total forest area where more recent or accurate information is available through other sources. Due to the significant variability in the quality of forest area data available among countries and underlying methodologies employed to generate such data-as well as meaningful differences in the policy relevance of these varying definitions of "forestland" at a country level-it is not possible to harmonize our approach. Further complicating matters, data on forest tenure distribution may only be compatible with one of multiple available data sets on the extent of forests. RRI is guided by efforts to publish the most comprehensive, up-to-date, and representative data available.

\section{Technical Notes for Collection of Forest Area Data}

1. Priority for selecting data sources will be as follows: (1) government information sources; (2) government figures cited by other organizations (e.g. FAO); and (3) trusted independent sources.

2. Only absolute numbers will be presented. Averages based on different sources will not be used.

3. In cases where it is impossible to find accurate absolute numbers, percentages from reliable sources may be applied to the total forest area presented in the same source or to the area of the legal forest estate.

4. Community-Based Tenure Regimes (CBTRs) form the sole unit of analysis for Categories 2 and 3, and therefore only community-based tenure rights are considered. The area under distinct tenure regimes found within countries are presented, rather than aggregates of "community owned or controlled lands" classified by another source (such as the FAO). CBTRs may also be considered as falling under Category 1 (government administration) due to the very limited nature of the rights recognized (i.e., access and withdrawal, but no management or exclusion rights); in these situations, data pertaining to the area of CBTRs is disaggregated from the remaining forest area under government administration in RRI's internal database where possible.

5. The most current and reliable data will be presented. Data points in original sources must refer to years spanning 2003-2017 if they are to be included in the 2017 column. If no data are available for years after 2002, the existing estimate for 2002 may be repeated if in-country sources confirm their current validity.

6. Retroactive changes to the 2002,2008 , and 2013 data sets will only be made where at least one of the following conditions are met: (1) data for 2002, 2008, or 2013 becomes available that was not previously available; (2) miscalculations were made in the 2002, 2008, or 2013 data; (3) further legal analysis requires the reclassification of a CBTR and associated area data under RRI's statutory forest typology; and/or (4) changes made in the definition of "forest area" or underlying source of data for total forest area require adaptation of the previous data to maintain time-series consistency.

7. In cases where the 2002 tenure data included "other wooded lands" (lands with 5-10 percent canopy cover, as defined by the FAO), the 2017 tenure data will also include other wooded lands.

8. Where possible, data points will be verified by country-level forest tenure specialists. Despite best efforts, it was not possible to obtain expert reviews for Gambia or Mozambique during the 2017 analysis. 


\section{Technical Notes Regarding the Disaggregation of Forest Area Privately Owned by Individuals and Firms}

1. RRI initially sought to disaggregate country-specific data on forests privately owned by individuals and firms (Category 4) into two sub-categories: (1) private forests owned by individual and family smallholders (including family-owned businesses), and (2) remaining private forests owned by firms (excluding small ownerships of family-owned businesses), legal persons, and individuals and families with medium and large holdings. However, RRI was unable to identify any data on smallholder forest ownership that included ownerships of family-owned businesses but excluded those of other firms. Consequently, smallholder area data presented in Box 1 pertains to smallholdings of individuals, families, and firms, without distinction regarding firm ownership.

2. Under no circumstances can the sum of the two sub-categories discussed above, or a single subcategory, exceed the forest area reported by RRI as being privately owned by individuals and firms (Category 4).

3. All forestland under Category 4 is held under individual tenure systems and national law recognizes the following rights to forestland for an unlimited duration: access, withdrawal, management, exclusion, due process and compensation, and sale.

4. Smallholder forest area was determined by using country-specific legal, policy and administrative definitions of "smallholder forest ownership" or analogous terms that can be used as a proxy to identify the extent of smallholder forest ownership. In the context of federal countries such as Canada, multiple proxy definitions applicable to specific provinces were employed.

5. Area data prior to 2002 was not presented.

6. Where multiple definitions of "smallholder forests ownership" (or an analogous term) exist within legislative policy and administrative documents, definitions found in forest and land laws/policies were given preference. Similarly, definitions found in forest laws were prioritized over those focused on land.

7. RRI sought to identify and present comprehensive area data on private smallholder forest ownerships, but best-available data only approached comprehensive coverage in two countries (Canada and Chile). Given the scarcity of available data, RRI elected to present area for an additional two countries (Argentina and Mexico) that represents only a subset of the total estimated smallholder forest area under private ownership (as defined under Category 4 of RRI's Statutory Forest Typology).

8. Given the scarcity of data concerning the extent of smallholder forest ownership, RRI has not presented any data on the remaining area of private forests owned by firms, legal persons, and individuals and families with medium and large holdings. 


\section{Report endnotes}

Rights and Resources Initiative. 2018. From Risk and Conflict to Peace and Prosperity: Securing Indigenous Peoples', communities', and women's land and forest rights to confront climate change and advance sustainable development, security, and wellbeing for all. Third Strategic Program from the Rights and Resources Initiative (RRI): 2018-2022. Rights and Resources Initiative, Washington, DC, 7. Available at: http://rightsandresources.org/wp-content/uploads/2017/12/ Strategic-Program-2018-2022_RRI_Dec-2017.pdf.

ii Rights and Resources Initiative. 2017a. Securing Community Land Rights: Priorities and Opportunities to Advance Climate and Sustainable Development Goals. Rights and Resources Initiative, Washington, DC, 4. Available at: https:// rightsandresources.org/en/publication/securing-community-land-rights-rri-brief/.

iii FAO. 2016a. Global Forest Resources Assessment 2015: How are the world's forests changing? Second Edition. Food and Agriculture Organization of the United Nations, Rome, 16. Available at: http://www.fao.org/3/a-i4793e.pdf.

iv 'Tree cover loss is not the same as deforestation. 'Tree cover' can refer to trees in plantations as well as natural forests, and 'tree cover loss' is the removal of tree canopy due to human or natural causes, including fire." Weisse, Mikaela and Elizabeth Dow Goldman. 2018. 2017 Was the Second-Worst Year on Record for Tropical Tree Cover Loss. World Resources Institute (WRI), Washington, DC. Available at: http://www.wri.org/blog/2018/06/2017-was-second-worstyear-record-tropical-tree-cover-loss.

$\checkmark \quad$ Global Witness. 2018. At What Cost? Irresponsible business and the murder of land and environmental defenders in 2017. Global Witness, London, 8-10. Available at: https://www.globalwitness.org/documents/19392/Defenders_report_ layout_AW2_lowres.pdf.

vi Rights and Resources Initiative. 2014. What Future for Reform? Progress and Slowdown in Forest Tenure Reform Since 2002. Rights and Resources Initiative, Washington, DC. Available at: https://rightsandresources.org/en/publication/ what-future-for-reform/\#.W3q-SPIKjIU.

vii Schlager, Edella, and Elinor Ostrom. 1992. Property-rights regimes and natural resources: a conceptual analysis. Land Economics 68(3): 249-262.

viii White, Andy and Alejandra Martin. 2002. Who Owns the World's Forests? Forest Tenure and Public Forests in Transition. Forest Trends and Center for International Environmental Law, Washington, DC. Available at: https://www. forest-trends.org/wp-content/uploads/imported/tenurereport_whoowns.pdf.

ix Global forest area comprises 3,999.13 mha as of 2015. FAO 2016a: 16.

x Rights and Resources Initiative. 2017b. Power and Potential: A Comparative Analysis of National Laws and Regulations Concerning Women's Rights to Community Forests. Rights and Resources Initiative, Washington, DC. Available at: https://rightsandresources.org/en/publication/power-and-potential/\#.W3IDE85KhhE.

xi FAO. 2015. Global Forest Resources Assessment 2015: Desk Reference. Food and Agriculture Organization of the United Nations, Rome. Available at: http://www.fao.org/3/a-i4808e.pdf.

xi Because forest tenure as of 2017 is not known for all categories in 17 countries, percentages in the preceding paragraph do not sum to 100 percent.

xiii In Mozambique, all lands belong to the state. However, communities have sufficient rights to constitute "ownership" under this study's methodology. Government of Mozambique. Lei de Terras - Lei No. 19/97 de 1 de Outubro, 1997. Art. 3. Available at: http://www.fao.org/faolex/results/details/en/c/LEX-FAOC015369; Government of Kenya. 2016. The Community Land Act, No. 27 of 2016. September 21, 2016. Available at: http://kenyalaw.org/kl/fileadmin/pdfdownloads/ Acts/CommunityLandAct_27of2016.pdf; Government of Mali. 2000. Code domanial et foncier, Ordonnance No. 00-027 du 22 mars 2000. Art. 43. Available at: http://www.droit-afrique.com/upload/doc/mali/Mali-Code-2000-domanial-etfoncier-MAI-2002.pdf; Government of Mali. 2006. Loi No. 06-045-AN/RM portant loi d'orientation agricole. September 5, 2006. Available at: http://extwprlegs1.fao.org/docs/pdf/mli67609.pdf; Government of Mali. 2017. Loi No. 2017-001, du 11 Avril 2017 portant sur le foncière agricole). Available at: http://www.fao.org/faolex/results/details/en/c/LEX-FAOC165599.

xiv Notably, past RRI forest area assessments excluded Liberia from the analysis of "complete case countries" for the same reason that Kenya, Mali, and Mozambique are presently excluded. However, Liberia's 2017 Community Rights Regulations revoke the wide-ranging acknowledgement of community forest ownership found in the 2009 Community Rights Law, requiring communities to execute a state-authorized management agreement before their forest ownership rights become legally actionable. Republic of Liberia. 2017. Regulation to the Community Rights Law of 2009 with Respect to Forest Lands, as Amended. May 17, 2017. Available at: https://www.documents.clientearth.org/wp-content/uploads/ library/2017-05-17-regulation-2017-forestry-development-authority-regulations-to-the-community-rights-law-withrespect-to-forest-lands-liberia-ext-en.pdf.

xv Calculated based on 2015 forest area data presented in the FAO Global Forest Resources Assessment 2015 and World Bank income classifications for the 2017 calendar year. Since RRI may cite a variety of verified sources for total 
forest area, FAO forest area data may not exactly correspond with RRI data at the country level. FAO 2015; World Bank. 2018. "World Bank Analytical Classifications (Presented in World Development Indicators): GNI per capita in US\$ (Atlas methodology)." Available at: http://databank.worldbank.org/data/download/site-content/OGHIST.xIs.

xvi Argentina, Belize, Chile, Ecuador, Guatemala, Kenya, Liberia, Malaysia, Mali, Mozambique, Nigeria, Panama, South Sudan, Sudan, Timor-Leste, Togo, and Venezuela are excluded from discussions of "complete case countries."

xvii These 30 countries include: Angola, Australia, Bhutan, Bolivia, Brazil, Cambodia, Cameroon, Canada, China, Colombia, Democratic Republic of the Congo, Ethiopia, Gabon, Guyana, Honduras, India, Indonesia, Lao PDR, Mexico, Mongolia, Myanmar, Nepal, Peru, Philippines, Sweden, Tanzania, Thailand, United States, Vietnam, and Zambia.

xviii These 21 countries include: Bhutan, Brazil, Cambodia, Cameroon, Canada, Colombia, Democratic Republic of the Congo, Gabon, Guyana, Honduras, India, Indonesia, Mongolia, Myanmar, Nepal, Peru, Philippines, Sweden, Tanzania, Vietnam, and Zambia.

xix FAO. 2016b. Forest Concessions, Past Present and Future. Food and Agriculture Organization of the United Nations, Rome, 1. Available at: http://www.fao.org/forestry/45024-0c63724580ace381a8f8104cf24a3cff3.pdf. See, for example, discussion of Indonesia's suspension of the issuance of new harvesting licenses in primary forest and peatland areas; Forest Legality Initiative. 2016. "Risk Tool: Indonesia." Accessed August 14, 2018. Available at: https://forestlegality.org/ risk-tool/country/indonesia.

xx Notess, Laura, Peter Veit, Iliana Monterroso, Andiko, Emmanuel Sulle, Anne M. Larson, Anne-Sophie Gindroz, Julia Quaedvelieg, and Andrew Williams. 2018. The Scramble for Land Rights: Reducing Inequity between Communities and Companies. World Resources Institute, Washington, DC. Available at: http://www.wri.org/publication/scramble-for-landrights.

xxi Forthcoming working paper on the extent of industrial concessions in the forested developing world. Prepared by Almeida Dohrn Consultoria LTDA for Rights and Resources Initiative.

xxii These 12 countries include: Bhutan, Canada, Central African Republic, Gambia, Honduras, Indonesia, Japan, Republic of Korea, Nepal, Sweden, Tanzania, and Zambia. In the 17 remaining countries where private forest ownership is possible under national law, sources cited in Table 1 reflect data from 2013 or earlier, but have been verified as the most recent available. Notably, private forest ownership only became legally possible under Zambian national law with the passing of the 2015 Forests Act. Government of Zambia. 2015. Forests Act, 2015 (Act No. 4 of 2015). August 14, 2015. Available at: http://www.fao.org/faolex/results/details/en/c/LEX-FAOC163377.

xxiii These 6 countries include: Bhutan, Central African Republic, Gambia, Indonesia, Nepal, and Tanzania.

xxiv These 5 countries include: Canada, Honduras, Japan, Republic of Korea, and Sweden

xxv In What Future for Reform (Rights and Resources Initiative 2014), Village Land Forest Reserves, Non-Reserved Forests on Village Lands, Community Forest Reserves, and Wildlife Management Areas were classified as "designated for Indigenous Peoples and local communities." These community-based tenure regimes have been reclassified as "owned by Indigenous Peoples and local communities" based on additional feedback from peer reviewers. See endnote 239 for additional information.

xxvi In What Future for Reform (Rights and Resources Initiative 2014), Dominio Util Consuetudinario (Useful Customary Domain) was classified as "designated for Indigenous Peoples and local communities." This community-based tenure regime was reclassified by RRI as "owned by Indigenous Peoples and local communities" in the 2015 Rights and Resources Initiative publication, Who Owns the World's Land, with support from peer reviewers. Notably, in Who Owns the World's Land, this community-based tenure regime was referenced as "Community Titles." This community-based tenure regime has been retitled as "Dominio Util Consuetudinario (Useful Customary Domain) to better reflect Angolan law. Rights and Resources Initiative. 2015. Who Owns the World's Land? A Global Baseline of Formally Recognized Indigenous and Community Land Rights. Rights and Resources Initiative, Washington, DC. Available at: https:// rightsandresources.org/en/publication/whoownstheland/\#.W3re1flKjlU. See endnote 4 for additional information.

xxvi Jaiteh, Muhammed. 2015. Gambia Case Study: Prepared for FAO as part of the State of the World's Forests 2016 (SOFO). Food and Agriculture Organization of the United Nations, Rome, 13. Available at: http://www.fao.org/3/a-c0182e. pdf.

xxviii Government of Senegal. 2013. Loi No. 2013-10 du 28 décembre 2013 portant code général des collectivités locales (hereinafter, "Loi No. 2013-10 du 28 décembre 2013"). December 28, 2013. Available at: http://www.au-senegal.com/ IMG/pdf/code_general6119.pdf.

xxix According to a 2017 Global Witness Report, "While the Prime Minister and Land Minister [of Papua New Guinea] have recently stated that SABLs are illegal and have been cancelled, at the time of writing the government had not issued any subsequent directives to cancel leases or halt operations under them." Global Witness. 2017. Stained Trade: How U.S. Imports of Exotic Flooring from China Risk Driving the Theft of Indigenous Land and Deforestation in 
Papua New Guinea. Global Witness, London and Washington, DC, 12-13. Available at: https://www.globalwitness.org/ documents/19150/stained_trade_310717_lores_pages.pdf.

xxx In Indonesia, indigenous communities are referred to as adat (mearing "customary"). Throughout this report, the two terms are used interchangeably.

xxxi Rights and Resources Initiative 2017a: 7.

xxxii Notably, the area designated for Indigenous Peoples and local communities in Bolivia through Agrupaciones Sociales del Lugar decreased by over 1 mha during the 2002-2017 period; however, the area owned by Indigenous Peoples and local communities grew by more than 8 mha over the same period.

xxxiii United States Census Bureau. 2010. "State Area Measurements and Internal Point Coordinates." Unpublished data from the MAF/TIGER database. Available at: https://www.census.gov/geo/reference/state-area.html\#n1.

xxxiv United Nations General Assembly. 2017. Resolution adopted by the General Assembly on 6 July 2017: Work of the Statistical Commission pertaining to the 2030 Agenda for Sustainable Development. United Nations, New York. Available from UN Doc. A/RES/71/313 at: https://undocs.org/A/RES/71/313.

xxxv Convention on Biological Diversity. 2016. Decision Adopted by the Conference of Parties to the Convention on Biological Diversity. Convention on Biological Diversity, Cancun, Mexico. Available from CBD/COP/DEC/XIII/28 at: https:// www.cbd.int/doc/decisions/cop-13/cop-13-dec-28-en.pdf.

xxxvi Bonn Challenge. 2018. "Commitments." Accessed August 18, 2018. Available at: http://www.bonnchallenge.org/ commitments.

xxxvii New York Declaration on Forest Global Platform. 2018. "New York Declaration on Forest Global Platform: Home." Accessed August 18, 2018. Available at: https://nydfglobalplatform.org/.

xxxviii Data refers to the area of 12 Local Community Forest Concessions (LCFCs) granted in 2018. No data was available on the area of the 15 additional LCFCs recognized as of July 2018. Ministère de l'Environnement et Développement Durable (MEDD) and World Resources Institute (WRI). 2018. "Concessions forestières des communautés locale." Atlas Forestier de la République Démocratique du Congo. Accessed August 10, 2018. Available at: http://cod-data.forest-atlas. org/datasets/concessions-foresti\%C3\%A8res-des-communaut\%C3\%A9s-locales.

xxxix Data published in Table 1 represents the area of Hutan Desa, Hutan Kemasyarakatan, and Hutan Tanaman Rakyat as of March 2017. All data refers to the area with work permits. Daryanto, Hadi. 2017. "Shared Learning Social Forestry in Indonesia as Access Tenure Reform." Presentation at World Bank Land and Poverty Conference 2017 (Slide 3), Washington, DC; Direktorat Jenderal Perhutanan Sosialdan Kemitraan Lingkungan. 2018. "Sinergitas Perhutanan Sosial." Presentation (Slide 3), Jakarta, Indonesia, February 20, 2018.

* See Phillips, Dom. 2018. "Their forefathers were enslaved. Now, 400 years later, their children will be landowners." The Guardian, March 5, 2018. Accessed July 15, 2018. Available at: https://www.theguardian.com/world/2018/mar/05/ descendants-of-slaves-celebrate-brazil-land-rights-victory?CMP=share_btn_tw; See also Branford, Sue and Maurício Torres. 2018. "Brazilian Supreme Court ruling protects Quilombola land rights for now." Mongabay, February 13, 2018. Accessed July 15, 2018. Available at: https://news.mongabay.com/2018/02/brazilian-supreme-court-ruling-protectsquilombola-land-rights-for-now/.

xii Government of Mexico. 2018. Ley General de Desarrollo Forestal Sustentable. April 26, 2018. Available at: http://dof. gob.mx/nota_detalle.php?codigo=5525247\&fecha=05/06/2018.

xlii Overview of Hutan Adat as provided by Gindroz, Anne-Sophie. 2018. Personal communication, Southeast Asia Facilitator, Rights and Resources Initiative, April 26, 2018.

xliii Rights and Resources Initiative 2014: 33.

xliv Data on the extent of CADTs in 2015 from: Republic of the Philippines, National Commission on Indigenous Peoples, Ancestral Domains Office provided by Maguigad, Edna. 2015. Personal communication, Lawyer, April 17, 2015; National Commission on Indigenous Peoples. 2012. As cited by Botengan, M. and Quicho. 2013. Mid-Term Progress Report on Incorporating IP Concerns in IEM. ENRMP, FASPO/DENR, Quezon City. In USAID. 2013. Assessment of REDD+ and Forestry Data in the Philippines: The AILEG Project. United States Agency for International Development, 43. Available at: http://pdf.usaid.gov/pdf_docs/PA00KSD2.pdf. Data on the extent of CADTs approved during the years 2002-2010 from: Philippine Partnership for the Development of Human Resources in Rural Areas (PhilDHRRA). 2011. Systematizing Access to Land Monitoring in the Philippines: Monograph. Asian NGO Coalition for Agrarian Reform and Rural Development (ANGOC) and International Land Coalition (ILC), 22. Available at: http://i.phildhrra.net/application/files/1214/7928/5606/ PhilDHRRA_access_to_land_monitoring_report_monograph-1.pdf.

xiv Global Witness 2018: 15-17.

xvi Guerrero Lovera, Cristian, Johana Herrera Arango, Elías Helo Molina, Adriana Beltrán Ruíz, Astolfo Aramburo 
Vivas, Sebastián Zapata, and María José Arrieta. 2017. Derechos Territoriales de las Comunidades Negras: Sistema de Información sobre la vulnerabilidad de los territorios sin titulación colectiva. Observatorio de Territorios Etnicos y Campesinos, Rights and Resources Initiative, Proceso de Comunidades Negras, and Pontificia Universidad Javeriana, Bogota, Colombia. Available at: http://etnoterritorios.org/CentroDocumentacion.shtml?apc=x-xx-1-\&x=1299.

xvii Government of Peru. 2018. Ley No. 30723. Ley que Declara de prioridad e interés nacional la construcción de carreteras en zonas de frontera y el mantenimiento de trochas carrozables en el departamento de Ucayali. January 22, 2018. Available at: https://busquedas.elperuano.pe/download/url/ley-que-declara-de-prioridad-e-interes-nacionalla-construcc-ley-n-30723-1608601-10; WWF. 2018. "WWF Peru on recently approved law 30723: more debate and reflection are urgently needed." World Wide Fund for Nature. Accessed January 24, 2018. Available at: http:// www.wwf.org.pe/en/?uNewsID=321530\&utm_content=buffer6520f\&utm_medium=social\&utm_source=twitter. com\&utm_campaign=buffer; Praeli, Yvette Sierra. 2018. "Peru: Law prioritizes highway construction that could threaten indigenous communities." Mongabay, February 27, 2018. Accessed March 15, 2018. Available at: https://news.mongabay. com/2018/02/peru-law-prioritizes-highway-construction-that-could-threaten-indigenous-communities/.

xvivii Barber, Christopher P., Mark A. Cochrane, Carlos M. Souza Jr., and William F. Laurance. 2014. Roads, deforestation, and the mitigating effect of protected areas in the Amazon. Biological Conservation, Volume 177, 203-209. Available at: https://www.sciencedirect.com/science/article/pii/S000632071400264X.

xlix Government of Senegal. 2013. Loi No. 2013-10 du 28 décembre 2013. Available at: http://www.au-senegal.com/ IMG/pdf/code_general6119.pdf.

I Government of Liberia. 2009. Community Rights Law. October 29, 2009. Secs. 1.5 and 2.1. Available at: http://www. fao.org/faolex/results/details/en/c/LEX-FAOC143892.

i) African Court on Human and Peoples' Rights. African Commission on Human and Peoples' Rights v. Republic of Kenya, Application No. 006/2012. Judgement, May 26, 2017. Available at: http://en.african-court.org/images/Cases/Judgment/ Application\%20006-2012\%20-\%20African\%20Commission\%20on\%20Human\%20and\%20Peoples\%E2\%80\%99\%20 Rights\%20v.\%20the\%20Republic\%20of\%20Kenya..pdf; Inter-American Court of Human Rights. Case of the Kaliña and Lokono Peoples v. Suriname. Judgment, November 25, 2015. Available at: http://www.corteidh.or.cr/docs/casos/articulos/ seriec_309_ing.pdf; and Caribbean Court of Justice. Maya Leaders Alliance v. The Attorney General of Belize, [2015] CC] 15 (AJ). Judgment, October 30, 2015. Available at: https://www.elaw.org/system/files/bz.mayaleaders_0.pdf.

lii Claridge, Lucy. 2018. Personal communication, Director of Strategic Litigation, Amnesty International, July 26, 2018; Okinda, Brian. 2018. "We are being unfairly targeted in Mau evictions, Ogiek say." Daily Nation, July 25, 2018. Accessed August 2, 2018. Available at: https://www.nation.co.ke/counties/narok/Ogiek-cry-foul-Mau-evictions/1183318-4681076oe3py3/index.html.

liii Forest Carbon Partnership Facility (FCPF) Carbon Fund. 2018. Emission Reductions Program Document (ER-PD) ER Program Name and Country: Promoting REDD+ through Governance, Forest landscapes \& Livelihoods in Northern Lao PDR. FCPF Carbon Fund, Washington, DC, 73. Available at: https://www.forestcarbonpartnership.org/sites/fcp/files/2018/ March/LaoPDR_ERPD\%20-\%20Advanced\%20Draft\%2026Mar18.pdf. 


\section{Table endnotes}

1 Law No. 6/2017 of Forest and Wildlife Basic Legislation establishes Rights to Community Use and Benefit, but it has yet to be seen whether implementing legislation associated with this CBTR will be consistent with a classification of "designated for Indigenous Peoples and local communities" or "owned by Indigenous Peoples and local communities." Government of Angola. 2017. Lei de Bases de Florestas e Fauna Selvagem. January 24, 2017. Art. 62(1), 64, 66, 68, 72. Available at: http://extwprlegs1.fao.org/docs/pdf/ang162520.pdf.

2 All forests in Angola were under government administration in 2002. FAO. 2014a. Global Forest Resources Assessment 2015, Country Report, Angola. Food and Agriculture Organization of the United Nations, Rome, 19. Available at: http://www.fao.org/3/a-az150f.pdf.

3 Calculated as total forest area minus the area "owned by Indigenous Peoples and local communities." FAO $2014 a: 19$.

4 In Who Owns the World's Land (RRI 2015), the CBTR then referred to as "Community Titles" (referred to in this publication as "Dominio Util Consuetudinario" or Useful Customary Domain) was reclassified as "owned by Indigenous Peoples and local communities." Data refers to the Comunidad de Julia, a community in the forested Huambo Province which has obtained a community title from the government. An additional nine communities have received titles, but area data is not available. The area for these additional titles is less than 10,000 hectares. Carranza, Francisco. 2013. Personal communication, Corrdenador Projecto Terra, FAO, October 2013. Data from: FAO. 2013. Delimited Rural Communities, Huambo Province, Angola [GIS Shapefile]. Food and Agricultural Organization of the United Nations, Rome. October 2013.

5 World Bank. 1993. Argentina Forestry Sector Review. Report 11833-AR, World Bank, Washington, DC. As cited by White and Martin 2002.

6 Refers to Bosques Nativos en Tierras Indígenas Comunales (Native Forests in Indigenous Communal Lands). Calculated as the sum of the area of Pueblos Originarios within the natural forests of Santiago del Estero and Formosa, as well as the area held by Aboriginal Communities within the natural forest of Salta. Notably, the same source also refers to an area of 660,423 ha within the natural forests of Chaco, but notes that whether these areas are fully titled has not been confirmed. As such, these were not included in calculations. According to peer review feedback in 2018, the "ordenamientos territoriales de los bosques nativos" (OTNB) for Salta went into effect in 2008, the OTNB for Santiago del Estero went into effect in 2009, and the OTNB for Formosa went into effect in 2010. Data from: Proyecto Manejo Sostenible de los Recursos Naturales. 2011. Componente Bosques Nativos y su Biodiversidad: Proyecto Manejo Sostenible de los Recursos Naturales - BIRF 7520-AR-PNUD ARG=(/008, Consultoría para temas previstos en Área técnica III. Buenos Aires, 100-101; Marinaro, Sofía. 2018. Personal communication, Professor, Instituto de Ecología Regional (IER), Universidad Nacional de Tucumán, March 28, 2018.

7 World Bank 1993. As cited by White and Martin 2002.

8 Calculated as total forest area reported minus the area "designated for Indigenous Peoples and local communities," "owned by Indigenous Peoples and local communities," and "privately owned by individuals and firms." Notably, total forest area for 2002 differs significantly from data published in previous RRI reports due to the "improved resolution of forest mapping resulting from the use of finer-scale vegetation data often complemented by interpreted satellite imagery incorporated through a Multiple Lines of Evidence (MLE) process" in Australia's 2013 State of the Forests Report. As described in Australia's 2015 Forest Resources Assessment Country Report, "To address the mapping inconsistencies between figures published in SOFR 1998, SOFR 2003, SOFR 2008 and SOFR, 2013, a set of derived forest extent figures have been calculated and reported for the purposes of the FRA 2015 for 1990, 2000, 2005, and 2010." Data from: FAO. 2014b. Global Forest Resources Assessment 2015, Country Report, Australia. Food and Agriculture Organization of the United Nations, Rome, 4-5 and 123. Available at: http://www.fao.org/3/a-az156e.pdf.

9 Refers to Leaseholds, Multiple-Use Public Forests, Nature Conservation Reserves, Unresolved Tenure, and Other Crown Lands that are not "Indigenous Owned and Managed," "Indigenous Managed," or "Indigenous Co-Managed." Data from: Dillon, Robert, Jeya Jeyasingham, Sid Eades, and Steve Read. 2015. Development of the Australia's Indigenous forest estate (2013) dataset, Research report 15.6. Australian Government, Australian Bureau of Agricultural and Resource Economics and Sciences (ABARES), Canberra, 25. Available at: http://data.daff.gov.au/data/warehouse/9aaf/aif/2013/ aif13d9abfs20150828/IndigenousForestEstate.pdf.

10 Available data for 2002 does not allow for disaggregation between forest areas "designated for Indigenous Peoples and local communities" and "owned by Indigenous Peoples and local communities," but has been included in this analysis as "owned by Indigenous Peoples and local communities."

11 Refers to the sum of data for "Indigenous Co-Managed," "Indigenous Managed" (except those in Nature Conservation Reserves), Leaseholds within "Indigenous Owned and Managed" Forests, and "Multiple Use Public Forest" within "Indigenous Owned and Managed" Forests as presented in Table 11 of Dillon et al. 2015: 25. 
12 Refers to forest area under Aboriginal ownership. Data from: Indigenous Land Corporation (ILC). Indigenous Land Corporation Corporate Plan 2003-06. As cited by Australia's Department of Agriculture, Fisheries and Forestry (DAFF). 2008. Australia's State of the Forests Report 2008. Bureau of Rural Sciences, Canberra, 157. Available at: http://data.daff. gov.au/data/warehouse/pe_brs90000003841/10_ASF08_c6_socio-econ.pdf.

13 Refers to the sum of data for "Indigenous Owned and Managed" Forests within Nature Conservation Reserves, Other Crown Land, and Private Forest, as well as Nature Conservation Reserves within "Indigenous Managed" Forests as presented in Table 11 of Dillon et al. 2015: 25. Notably, the lower area presented for 2017 is indicative of more detailed data that allows for more nuanced disaggregation of data than is possible for the year 2002. Area presented for 2017 does not reflect an actual decrease in forest area "owned by Indigenous Peoples and local communities."

${ }^{14}$ Calculated as total Private Forest area minus the area "owned by Indigenous Peoples and local communities." FAO 2014b: 123.

15 Calculated as total Private Forest area minus the area of Private "Indigenous Forest" as presented in Table 11 of Dillon et al. 2015: 25 .

16 No disaggregated data is available on Maya Lands or Indian Reserves for the year 2002. As of the 2015 Caribbean Court of Justice judgment Maya Leaders Alliance v. The Attorney General of Belize, all forests within Indian Reserves are owned by Indigenous Peoples as Maya Lands. However, no disaggregated area data is available for Maya Lands as of 2017.

17 Calculated as total forest area minus the area "designated for Indigenous Peoples and local communities" and "privately owned by individuals and firms." Data on total forest area from: FAO. 2014c. Global Forest Resources Assessment 2015, Country Report, Bhutan. Food and Agriculture Organization, Rome, 76. Available at: http://www.fao.org/3/a-az168e.pdf.

${ }^{18}$ Calculated as total forest area minus the area "designated for Indigenous Peoples and local communities" and "privately owned by individuals and firms." Data on total forest area from: Department of Forests and Park Services. 2016. National Forest Inventory Report: Stocktaking Nation's Forest Resources, Volume 1. Royal Government of Bhutan. Available at: http://www.dofps.gov.bt/wp-content/uploads/2017/07/National-Forest-Inventory-Report-Vol1.pdf.

19 Refers to data as of 2002 for Community Forests. Data from: Bhutan Social Forestry Division. 2011. As cited by Chhetri, B.B. 2011. Forest Tenure Assessment in Bhutan - An Overview (Draft). Ministry of Agriculture and Forests, Thimpu, 10.

20 Refers to Community Forests. Data from: Social Forestry and Extension Division, Department of Forests and Park Services. As cited by Temphel, Karma Jigme. 2018. Personal communication, Social Forestry and Extension Division, Department of Forests and Park Services, January 31, 2018.

${ }^{21}$ A very small area of forest is privately owned by individuals where trees have been planted on legally registered private land. See the Forest and Nature Conservation Rules and Regulations of 2017, Arts. 124-134 and 436. See also the Land Act of 2007, Arts. 58-68 and 93-94 for additional information. Data from: FAO 2014c: 76. Legislation cited: Royal Government of Bhutan, Ministry of Agriculture and Forests, Department of Forests and Park Services. 2017. Forest and Nature Conservation Rules and Regulations of Bhutan, 2017. Thimphu, Arts. 124-134 and 436. Available at: http://www. dofps.gov.bt/wp-content/uploads/2017/02/FNCRR2017.pdf; Royal Government of Bhutan. 2007. Land Act of Bhutan 2007. Arts. 58-68 and 93-94. Available at: http://oag.gov.bt/wp-content/uploads/2010/05/Land-Act-of-Bhutan-2007_ English.pdf.

22 A very small area of forest is privately owned by individuals where trees have been planted on legally registered private land. See the Forest and Nature Conservation Rules and Regulations of 2017, Arts. 124-134 and 436. See also the Land Act of 2007, Arts. 58-68 and 93-94 for additional information. Data from: Social Forestry and Extension Division (SFED), Department of Forests and Parks Services, Ministry of Agriculture and Forests and FAO. 2018. Assessment of Extent and Effectiveness of Community Based Forestry in Bhutan. Unpublished Report. SFED and FAO, 15. Legislation cited: Royal Government of Bhutan, Ministry of Agriculture and Forests, Department of Forests and Park Services. 2017. Forest and Nature Conservation Rules and Regulations of Bhutan, 2017. January 2017. Arts. 124-134 and 436. Available at: http:// www.dofps.gov.bt/wp-content/uploads/2017/02/FNCRR2017.pdf; Royal Government of Bhutan. 2007. Land Act of Bhutan, 2007. June 27, 2007. Arts. 58-68 and 93-94. Available at: http://oag.gov.bt/wp-content/uploads/2010/05/LandAct-of-Bhutan-2007_English.pdf.

${ }^{23}$ Calculated as total forest area minus the area "designated for Indigenous Peoples and local communities," "owned by Indigenous Peoples and local communities," and "privately owned by individuals and firms." Data on total forest area from: FAO. 2014d. Evaluación de los Recursos Forestales Mundiales 2015, Informe Nacional, Bolivia. Food and Agriculture Organization of the United Nations, Rome, 25. Available at: http://www.fao.org/3/a-az169s.pdf.

${ }^{24}$ Calculated as total forest area minus the area "designated for Indigenous Peoples and local communities," "owned by Indigenous Peoples and local communities," and "privately owned by individuals and firms." Data on total forest area 
from: FAO 2014d: 25.

25 Refers to the cumulative total of Agrupaciones Sociales del Lugar (ASL) (Location-Based Social Associations) granted from 1997-2002. Data from: Director General for Forest Resources, Republic of Bolivia, and FAO-Bolivia. 2007. Base de datos sobre el Sector Forestal de Bolivia 1997 a 2006: Proyecto TCP/BOL/3102. Republic of Bolivia and Food and Agriculture Organization of the United Nations, La Paz, 10.

26 Refers to Agrupaciones Sociales del Lugar (ASL) (Location-Based Social Associations) "vigentes" larger than 200 ha. Data from: Autoridad de Fiscalización y Control Social de Bosques y Tierras (ABT). 2010. Unpublished data. As cited by LIDEMA. 2010. Informe del Estado Ambiental de Bolivia 2010. Liga de Defensa del Medio Ambiente (LIDEMA), La Paz, 329.

27 Refers to Propiedades Comunitarias (Communal Property) and Territorios Indígenas Originarios Campesinos (Original Peasant Indigenous Territory). Data for Propiedades Comunitarias from: Republic of Bolivia and FAO-Bolivia 2007: 10. Data for Territorio Indígena Originario Campesino from White and Martin. 2002.

28 Refers to Propiedades Comunitarias (Communal Property), Territorios Indígenas Originarios Campesinos (Original Peasant Indigenous Territory), and Títulos Comunales para Comunidades Agro-Extractivistas (Norte Amazónico) (Communal Titles for Agricultural-Extractivist Communities in the Northern Amazonian Region). Data for Propiedades Comunitarias and Territorios Indígena Originario Campesinos from: Fundacion Tierra. 2011. Territorios Indígenas Originarios Campesinos en Bolivia Entre la Loma Santa y la Pachamama. Fundacion Tierra, La Paz, 130 and 214. Data for Títulos Comunales para Comunidades Agro-extractivitas (Norte Amazónico) from: Instituto Nacional para Reforma Agraria (INRA). 2007. Unpublished data. As cited by Pacheco, Pablo, Deborah Barry, Peter Cronkleton and Anne M. Larson. 2009. El papel de las instituciones informales en el uso de los recursos forestales en América Latina. Center for International Forestry Research (CIFOR), Bogor, 38.

${ }^{29}$ Republic of Bolivia and FAO-Bolivia 2007: 10.

30 Refers to the sum of areas of Proprietario Privado (Private Property) that are both smaller than 200 ha and larger than 200 ha. Data from: ABT 2010. As cited by LIDEMA 2010: 329-330.

31 Calculated as total forest area minus the area "designated for Indigenous Peoples and local communities," "owned by Indigenous Peoples and local communities," and "privately owned by individuals and firms." Notably, the method of calculation used to derive total forest area in past RRI publications resulted in a lower estimate of total forest area than figures presented elsewhere. As such, data on total forest area in Brazil has been adjusted in this analysis, impacting estimates of "government administered forest" as of 2002. Data on total forest area from: FAO. 2014e. Global Forest Resources Assessment 2015, Country Report, Brazil. Food and Agriculture Organization of the United Nations, Rome, 27. Available at: http://www.fao.org/3/a-az172e.pdf.

32 Calculated as total forest area minus the area "designated for Indigenous Peoples and local communities," "owned by Indigenous Peoples and local communities," and "privately owned by individuals and firms." Data on total forest area from: FAO 2014e: 27.

33 Refers to Reservas Extrativistas (RESEX) (Extractive Reserves), Reservas de Desenvolvimento Sustentável (Sustainable Development Reserves), Projetos de Assentamento Florestal (PAF) (Forest Settlement Projects), Projeto de Desenvolvimento Sustentavel (PDS) (Sustainable Development Project), and Projetos de Assentamento (PAE) AgroExtrativista (Agro-Extractivist Settlement Project). Data represents the sum of Reservas Extrativistas and Reservas de Desenvolvimento Sustentável in both federal and state forests in the legal Amazon, from: Instituto Socioambiental/ Programa Monitoramento de Áreas Protegidas. 2017. SisArp (Sistema de Áreas Protegidas). As provided by Bensusan, Nurit. 2018. Personal communication, Deputy Coordinator of the Socio-environmental Policy and Law Program, Instituto Socioambiental, January 18, 2018.

34 Refers to Reservas Extrativistas (RESEX) (Extractive Reserves), Reservas de Desenvolvimento Sustentável (Sustainable Development Reserves), Projetos de Assentamento Florestal (PAF) (Forest Settlement Projects), Projetos de Desenvolvimento Sustentavel (PDS) (Sustainable Development Project), and Projeto de Assentamento Agro-Extrativista (PAE) (Agro-Extractivist Settlement Project). Data on Reservas Extrativistas and Reservas de Desenvolvimento Sustentável includes both Federal and State forests in the legal Amazon from: Instituto Socioambiental/Programa Monitoramento de Áreas Protegidas 2017. As cited by Bensusan 2018. Data for Projetos de Assentamento Florestal, Projetos de Desenvolvimento Sustentavel, and Projetos de Assentamento Agro-Extrativista refers to 4.7 percent of the public forest recorded in the national cadaster of public forest. This includes federal public forests and state and municipal forests that voluntarily reported to the cadaster. Data from: Brazilian Forest Service 2016. As cited by Government of Brazil, Ministry of the Environment, Brazilian Forest Service. Plano anual de outorga florestal 2018. Brazilian Forest Service, Brasília, 17, 35, and 41. Available at: http://www.florestal.gov.br/documentos/publicacoes/3536-paof-2018-final-1/file. 
35 Refers to Terras Indígenas (Indigenous Lands) and Territórios Quilombolas (Quilombola Communities). Data for Terras Indígenas from: Tresierra, Julio. 1999. Rights of Indigenous Peoples over Tropical Forest Resources. Inter-American Development Bank, Washington, DC. As cited by White and Martin 2002. Data for Territórios Quilombolas includes forest and non-forestlands and does not disaggregate among land types; however, there is a significant overlap between Territórios Quilombolas and forestlands. Data includes titles established prior to December 2002 from: Government of Brazil, National Institute of Colonization and Agrarian Reform (INCRA). 2013. "Títulos Expedidos às Comunidades Quilombolas." Government of Brazil, National Institute of Colonization and Agrarian Reform. Accessed July 8, 2013. Available at: http://www.incra.gov.br/estrutura-fundiaria/quilombolas/file/1792-titulos-expedidos-as-comunidadesquilombolas.

36 Refers to Terras Indígenas (Indigenous Lands) and Territórios Quilombolas (Quilombola Communities). Data for Terras Indígenas represents areas within national public forests where the recognition process has been concluded, from: Brazilian Forest Service. 2016. As cited by Brazilian Forest Service 2018: 23. Data for Territórios Quilombolas includes forest and non-forestlands and does not disaggregate among land types; however, there is a significant overlap between Territórios Quilombolas and forestlands. Data from: Government of Brazil, National Institute of Colonization and Agrarian Reform (INCRA). 2016. “Dados Gerais Quilombolas. Quadro Atual da Política de Regularização de Territórios Quilombolas no INCRA. Títulos Emitidos." Updated at: 05/02/2016. Government of Brazil, National Institute of Colonization and Agrarian Reform. Accessed June 23, 2018. Available at: http://www.incra.gov.br/tree/info/file/8797.

37 Refers to the area of woods and forests in agriculture and livestock establishments in Brazil, from the 1995 Agriculture and Livestock Census. Data from: Brazilian Institute of Geography and Statistics (IBGE). 1995. As cited by FAO. 2010a. Global Forest Resource Assessment 2010, Country Report, Brazil. Food and Agriculture Organization of the United Nations, Rome, 23. Available at: http://www.fao.org/docrep/013/al464E/al464E.pdf.

38 Refers to the area of woods and forests in agriculture and livestock establishments in Brazil, from the 2006 Agriculture and Livestock Census. Data from: Brazilian Institute of Geography and Statistics (IBGE). 2006. As cited by FAO 2010a: 23.

39 Calculated as total forest area minus the area "designated for Indigenous Peoples and local communities" and "owned by Indigenous Peoples and local communities." Data for total forest area from: Forest Authority. 2016. As cited by Kim, Menglim. 2017. Personal communication, USAID Cambodia, Project Management Specialist, September 27, 2017.

40 Calculated as total forest area minus the area "designated for Indigenous Peoples and local communities" and "owned by Indigenous Peoples and local communities." Data on total forest area was calculated as 45.26 percent of total land area. Ministry of Environment. August 17, 2017. As cited by Kim 2017.

${ }^{41}$ Refers to Community Forests with signed management agreements with MAFF and Community Protected Areas. Data for Community Forests with signed management agreements with MAFF from: Forestry Administration. January 2017 Community Forest Statistic. As cited by Kim 2017. Data for Community Protected Areas from: Ministry of Environment, Department of Community Livelihoods. As cited by Kim 2017.

42 Only Spiritual and Burial Forestlands within Indigenous Communities' Lands can legally fall within the permanent forest estate, and the area of each may not exceed 7 ha per community. See Kingdom of Cambodia. 2009. Sub Decree on Procedures of Registration of Land of Indigenous Communities. June 9, 2009. Article 6. Available at: https://theredddesk. org/sites/default/files/sub-decree_on_procedures_of_registration_of_land_of_indigenous_communities.pdf. As of 2017, there were 20 "Registered Indigenous Communal Lands" covering an area of 15,893.78 ha. The area of those lands which are Spiritual and Burial Forestlands is therefore small, but unknown. Open Development Cambodia. 2016. "Registered indigenous communal land." Accessed May 29, 2018. Available at: https://opendevelopmentcambodia.net/profiles/ indigenous-communities/.

43 Calculated as total forest area minus the forest area "designated for Indigenous Peoples and local communities" and "privately owned by individuals and firms." Data for total forest area from: FAO. 2014f. Evaluation des Ressources Forestières Mondiales 2015, Rapport National, Cameroun. Food and Agriculture Organization of the United Nations, Rome, 96. Available at: http://www.fao.org/3/a-az183f.pdf.

${ }_{44}$ Calculated as total area of the permanent and non-permanent forest domains, minus the forest area "designated for Indigenous Peoples and local communities" and "privately owned by individuals and firms." Data for total forest area from: Cameroon Ministry of Forestry and Wildlife (MINOF). 2017. Secteur forestier et faunique du Cameroun : faits et chiffres. MINOF, Yaoundé, 14. Available at: http://pfbc-cbfp.org/actualites/items/Faits-chiffres.html. Notably, increase in total forest area as compared with the FAO Global Forest Resources Assessment Country Report for Cameroon may reflect differences in methodology rather than actual increase in forest area.

45 Refers to 274 Forêts Communautaires (Community Forests) with signed final conventions and those with signed provisional convention agreements, as well as Zones d'intérêt cynégétique à gestion communautaire (Community Managed Hunting Zone). All data from MINFOF 2017: 14 and 18. 
46 Private forests are legally possible in Cameroon (see Arts. 34 and 39 of Law No. 94/01 of 20 January 1994). Although this analysis lists private forest area as zero hectares for all years, there is a marginal but unknown amount of private forest. As explained in Table 18.3.1 of FAO 2014f, "it is useful to specify that all the forests belong to the State except the private forests of individuals whose existence is still marginal in Cameroon." FAO 2014: 93. Legislation cited: Government of the Republic of Cameroon. 1994. Loi No. 94/01 du 20 janvier 1994 portant régime des forêts, de la faune et de la pêche (herinafter, "Loi No. 94/01 du 20 janvier 1994"). Arts. 34, 39. Available at: http://www.wipo.int/edocs/lexdocs/laws/ $\mathrm{fr} / \mathrm{cm} / \mathrm{cm} 007 \mathrm{fr} . \mathrm{pdf}$.

47 Private forests are legally possible in Cameroon (see Arts. 34 and 39 of Loi No. 94/01 du 20 janvier 1994). Although this analysis lists private forest area as zero hectares for all years, there is a marginal but unknown amount of private forest. As explained in Table 18.3.1 of FAO 2014f, "it is useful to specify that all the forests belong to the State except the private forests of individuals whose existence is still marginal in Cameroon." FAO 2014f: 93. Legislation cited: Government of the Republic of Cameroon. 1994. Loi No. 94/01 du 20 janvier 1994. Arts. 34, 39.

${ }^{48}$ Classification of data as "government administered," "designated for Indigenous Peoples and local communities," and "owned by Indigenous Peoples and local communities" from: Nikolakis, William and Sara Weber. 2018. RRI Consultant Report - Legal analysis on Community Based Tenure Regimes in Canada for the Rights and Resources Initiative. Unpublished report. The land and forest rights of First Nations in Canada are recognized through a multitude of Modern Treaties and Agreements and Aboriginal Land Titles beyond those listed here, but limited forest-specific data on the area-based extent of these holdings is available. The treaties and agreements listed in the following endnotes thus represent only those for which forest-specific data is available, and do not constitute a comprehensive list of all legal mechanisms by which the First Nations of Canada have recognized rights at the national or subnational level.

${ }^{49}$ Calculated as total forest area minus the area "designated for Indigenous Peoples and local communities," "owned by Indigenous Peoples and local communities," and "privately owned by individuals and firms." Data on total forest area from: Canada's National Forest Inventory. Revised 2006 baseline. 2006. As cited by FAO. 2014g. Global Forest Resources Assessment 2015, Country Report, Canada. Food and Agriculture Organization, Rome, 15. Available at: http://www.fao. org/3/a-az181e.pdf. See also: Natural Resources Canada. 2016. State of Canada's Forests: Annual Report 2016. Natural Resources Canada, 19. Available at: http://cfs.nrcan.gc.ca/pubwarehouse/pdfs/37265.pdf.

50 Calculated as total forest area minus the area "designated for Indigenous Peoples and local communities," "owned by Indigenous Peoples and local communities," and "privately owned by individuals and firms." Data on total forest area from: Canada's National Forest Inventory. Revised 2006 baseline. 2006. As cited by FAO 2014g: 15. See also: Natural Resources Canada 2016.

51 Refers to the forest area (9 percent) of Kluane National Park, and represents a minimum figure of forest area under the Kluane First Nation Final Agreement. Data from: Henry, David, Anne Landry, Tom Elliot, Laura Gorecki, Michael Gates, and Channy Chow. 2008. State of the Park Report: Kluane National Park and Reserve Canada. Parks Canada, ii and 13. Available at: https://www.pc.gc.ca/en/agence-agency/bib-lib/ / media/4334D912B761468398C45FA006552CD1.ashx.

52 Refers to the sum of forest area (9 percent) of Kluane National Park and First Nations Woodland Licenses (FNWLS) issued in British Columbia. Forest area of Kluane National Park represents a minimum figure of forest area under the Kluane First Nation Final Agreement. Data from: Henry et al. 2008: ii and 13. Data on First Nations Woodland Licenses refers to nine FNWLs issued as of January 2017. Data from: Ministry of Forests, Lands, Natural Resource Operations \& Rural Development. 2017. Issued First Nations Woodland Licenses. Province of British Columbia. Available at: https:// www.for.gov.bc.ca/ftp/HTH/external/!publish/web/timber-tenures/FNWL/Issued-FNWL-Tracker.pdf.

${ }_{53}$ Refers to "land owned by first nations" according to the 2006 re-measurement of Canada's National Forest Inventory (as cited by FAO 2014g: 41), minus forest areas considered "designated for Indigenous Peoples and local communities" as of 2002 under this analysis.

54 Refers to "land owned by first nations" according to the 2006 re-measurement of Canada's National Forest Inventory (as cited by FAO 2014g), plus available forest area data for Modern Treaties and Agreements and Aboriginal Land Titles that have come into effect since 2006. Data for Maa-nulth First Nations Treaty from: Rights and Resources Initiative 2014. Data for Tsawwassen First Nation Treaty from: Tsawwassen First Nation. 2009. "Tsawassen First Nation Land Use Plan." AECOM Technology Corporation. http://www.tsawwassenfirstnation.com/ TFN_Land_Use_Plan.pdf. Data for Tsilhqot'in Nation Declared Aboriginal Title Land from: Tsilhqot'in Nation v. British Columbia, [2014] 2 SCR 256, 2014 SCC 44 (CanLII), as cited by Nikolakis and Weber 2018. Data for Tla'amin Final Agreement refers to the "timber harvest land base" of Sliammon Community Forest. The Sliammon Development Corporation "manages forestry matters for the Tla'amin Nation." See Powell River Forestry Heritage Society. 2018. "Thichum Forest Products." Accessed June 18, 2018. Available at: http://www.prfhs.org/paradise-valley-railroad/ 
pvr-development/pvr-rolling-stock/37-organization/harvest-contractor. No forest-specific data on the extent of Reserves is available.

55 Legal analysis by Nikolakis, William and Evan H. Powell. 2018. RRI Consultant Report - Canada Category 4 Data. Unpublished report. Data from: FAO 2014g: 90.

56 Legal analysis by Nikolakis and Powell 2018. Data from: FAO 2014g: 90.

57 As of 2000, all forests were under government administration. Data on total forest area from: FAO 2014h. Evaluation des Ressources Forestières Mondiales 2015, Rapport National, République centrafricaine. Food and Agriculture Organization of the United Nations, Rome, 17. Available at: http://www.fao.org/3/a-az183f.pdf. It should be noted that riparian communities have customary use rights throughout most "government administered" forests, with the exception of certain protected areas. Pichon, Marjolaine. Personal communication, Central African Republic Coordinator, Rainforest Foundation UK, March 2018. See also Government of the Central African Republic. 2008. Loi No. 08-022, Portant code forestier de la République centrafricaine (hereinafter, "Loi No. 08-022, Portant code forestier de la République Centrafricaine"). October 17, 2008. Arts. 14-15. Available at: http://www.fao.org/faolex/results/details/en/c/LEXFAOC107432. Finally, "government administered" forest area includes Forêt de collectivités (Forests of Local Collectives). In the past, RRI has classified these forests as "designated for Indigenous Peoples and local communities," but feedback during the peer review process clarified that these forests are governed by administrative bodies that do not qualify as community-based entities. Consequently, Forêt de collectivités have been reclassified as "government administered." Pichon 2018.

${ }^{58}$ Calculated as total forest area minus the area "privately owned by individuals and firms." Data on total forest area from: FAO 2014h: 17. It should be noted that riparian communities have customary use rights throughout most "government administered" forests, with the exception of certain protected areas. Pichon 2018. See also Government of the Central African Republic. 2008. Loi No. 08-022, Portant code forestier de la République centrafricaine. Finally, "government administered" forest area includes Forêt de collectivités (Forests of Local Collectives). In the past, RRI has classified these forests as "designated for Indigenous Peoples and local communities," but feedback during the peer review process clarified that these forests are governed by administrative bodies that do not qualify as community-based entities. Consequently, Forêt de collectivités have been reclassified as "government administered." Pichon 2018.

59 Refers to forêts communautaires (Community Forests). Implementing legislation for this CBTR was passed in December 2015, but these are still under development. Data from: Rainforest Foundation UK. 2017. Le Nouvel Elan de la Foresterie Communautaire en République Centrafricaine: Opportunités, défis et enjeux de la gestion des forêts par les communautés locales et autochtones. London. Available at: http://www.rainforestfoundationuk.org/media.ashx/carforesterie-communautaire-2017.pdf.

${ }^{60}$ Nature Economy and People Connected (NEPCon). "Central African Republic Timber Risk Profile." Accessed April 24, 2018. Available at: https://www.nepcon.org/sourcinghub/timber/timber-central-african-republic.

${ }^{61}$ Calculated as total forest area minus the area "owned by Indigenous Peoples and local communities" and "privately owned by individuals and firms." Data on total forest area from: CONAF. 2017. "Superficie de Usos de Suelo Regional, en Hectareas: Ano 2017." Available at: https://sit.conaf.cl/tmp/obj_905751/1906_Superficies\%20Catastros\%20Usos\%20 de\%20Suelos\%20y\%20recursos\%20vegetacionales\%20Agosto2017.pdf.

62 Refers to Agricultural Communities and Forests in Indigenous Territories. According to personal communication with José Aylwin, only the Mapuche Indigenous Territory in the south of the country is located in forestland. Data for Indigenous Territories from: Registro público de Tierras de CONADI, 2010. As cited by Government of Chile. 2012. Informes Periódicos 19, 20 y 21 de Aplicación de la Convención Internacional Sobre la Eliminación de todas las formas de Discriminación Racial: De conformidad al artículo $9^{\circ}$ de la Convención, Chile. 53. Available at: http://www.minrel.gob.cl/ minrel/site/artic/20080902/asocfile/20080902204316/informe_19_20_21_icerd_versi_n_final_05_09_2012.pdf; Aylwin, José. 2017. Personal communication, Co-Director, Observatorio Ciudadano.

${ }^{63}$ Calculated as private forest area as of 2010 minus the area "owned by Indigenous Peoples and local communities." Data from: FAO. 2014i. Evaluación de los Recursos Forestales Mundiales 2015, Informe Nacional, Chile. Food and Agriculture Organization of the United Nations, Rome, 92. Available at: http://www.fao.org/3/a-az185s.pdf.

${ }^{64}$ Refers to state-owned forests. Data from: Sixth National Forest Inventory. 2001. As cited by FAO. 2014j. Global Forest Resources Assessment 2015, Country Report, China. Food and Agriculture Organization of the United Nations, Rome, 100. Available at: http://www.fao.org/3/a-az186e.pdf.

65 Refers to state-owned forests. Data from: Eighth National Forest Inventory. 2011. As cited by FAO 2014j: 100.

66 Refers to forests under Collective Ownership and includes forests managed by households. Data from: Sixth National Forest Inventory. 2001. As cited by FAO 2014j: 100. 
67 Refers to forests under Collective Ownership and includes forests managed by households. Data from: Eighth National Forest Inventory. 2011. As cited by FAO 2014j: 100.

68 Calculated as total forest area minus the forest area "owned by Indigenous Peoples and local communities." Data for total forest area from: Instituto de Hidrología, Meteorología y Estudios Ambientales - IDEAM. Subdirección de Ecosistemas e Información Ambiental. Grupo de Bosques 2017. Proyecto Sistema de Monitoreo de Bosques y Carbono (SMBYC). Bogotá and DC. As cited by IDEAM 2016. "Colombia. Proporción de la superficie cubierta por bosque natural. 1990, 2000, 2005, 2010, 2012, 2013, 2014, 2015, 2016."

${ }^{69}$ Calculated as total natural forest area minus the forest area "owned by Indigenous Peoples and local communities." Data on total forest area from: IDEAM. 2017. Reporte Anual de la tasa de deforestación para el año 2016. As cited by MINAMBIENTE 2017. Estrategia Integral de Control a la Deforestación y Gestión de los Bosques (EICDGB). Bogota, 23. Available at: http://www.minambiente.gov.co/images/EICDGB_1.0_AGOSTO_9_2017.pdf.

70 Refers to Resguardos Indígenas (Indigenous Reserves) and Tierras de las Comunidades Negras (Afro-Colombian Community Lands). Ng'weno, Bettina. 2000. On Titling Collective Property, Participation and Natural Resource Management: Implementing Indigenous and Afro-Colombian Demands. A Review of Bank Experience in Colombia. World Bank. As cited by White and Martin. 2002.

71 Refers to Resguardos Indígenas (Indigenous Reserves), Tierras de las Comunidades Negras (Afro-Colombian Community Lands), and Zonas de Reserva Campesina (ZRC) (Peasant Reserve Zones). Of the 32.1 mha of Resguardos Indígenas as of 2015, 46.3 percent is within forestlands. Data from: IDEAM. 2017. Mapa bosques de 2015. As cited by MINAMBIENTE 2017: 45. Data for Tierras de las Comunidaded Negras from: IDEAM 2017. As cited by MINAMBIENTE 2017: 47. Forest-specific data on the extent of collectively-titled ZRCs was not available.

72 Calculated as total forest area minus the area "owned by Indigenous Peoples and local communities" and "privately owned by individuals and firms." Data on total forest area from: Sistema Nacional de Áreas de Conservación (SINAC). 1999. Tenencia de las Tierras Estatales. Costa Rica. As cited by FAO. 2014k. Evaluacion de los Recursos Forestales Mundiales 2015, Informe Nacional, Costa Rica. Food and Agriculture Organization of the United Nations, Rome, 120. Available at: http://www.fao.org/3/a-az191s.pdf.

73 Calculated as total forest area minus the area "owned by Indigenous Peoples and local communities" and "privately owned by individuals and firms." Data on total forest area from: FONAFIFO. 2007. As cited by Ulate Chacón, Enrique Napoleón. 2009. Implicaciones de la tenencia y la gestión forestal en la reducción de la pobreza en Costa Rica. Food and Agriculture Organization of the United Nations, Rome. 7. Available at: http://www.fao.org/forestry/17193-098b5271e6025 595e03de2db82644ad60.pdf.

74 Refers to Territorio Indígena (Indigenous Territory). Data from: Sistema Nacional de Áreas de Conservación (SINAC). 1999. Tenencia de las Tierras Estatales. Costa Rica. As cited by FAO 2014k: 120.

75 Refers to Territorio Indígena (Indigenous Territory). Data from: FONAFIFO 2007. As cited by Ulate Chacón 2009: 7.

76 Sistema Nacional de Áreas de Conservación (SINAC) 1999. As cited by FAO 2014k: 120.

77 FONAFIFO 2007. As cited by Ulate Chacón 2009: 7.

78 All forests remained under government administration as of 2002. Data for total forest area from: FAO. 2014l. Global Forest Resources Assessment 2015, Country Report, Democratic Republic of the Congo. Food and Agriculture Organization of the United Nations, Rome, 13. Available at: http://www.fao.org/3/a-az875f.pdf.

79 Calculated as total forest area minus the area "designated for Indigenous Peoples and local communities," and includes areas of Community Use Rights Within Permanent Production Forests and Local Population Use Rights Within Classified Forest. Data on total forest area from: FAO 2014l: 13. Data on Community Use Rights Within Permanent Production Forests and Local Population Use Rights Within Classified Forest from: World Resources Institute and Ministère de l'Environnement, Conservation de la Nature et Tourisme de la République Démocratique du Congo. 2010. «Atlas forestier interactif de la République Démocratique du Congo - version 1.0 : Document de synthèse.» World Resources Institute, Washington, DC, 14.

80 Refers to Local Community Forest Concessions (LCFCS) and Community Reserves (Conservation concessions allocated to communities). Despite the recognition of the basic framework for LCFCs under the 2002 Forest Code, LCFCs could not be classified as "designated for Indigenous Peoples and local communities" until the passage of implementing legislation (Decree No. 14/018 2014) in 2014. Ministère de l'Environnement et Développement Durable (MEDD) and World Resources Institute (WRI). 2018. "Concessions forestières des communautés locale." Atlas Forestier de la République Démocratique du Congo. Accessed August 10, 2018. Available at: http://cod-data.forest-atlas.org/ datasets/concessions-foresti\%C3\%A8res-des-communaut\%C3\%A9s-locales.

${ }^{81}$ Forest ownership is unknown for more than half of total forest area presented in the 2015 Global Forest Resources Assessment Country Report for Ecuador, and therefore no data on forests that are "government administered" or 
"privately owned by individuals and firms" is available. Data on total forest area from: FAO. 2014m. Evaluación de los Recursos Forestales Mundiales 2015, Informe Nacional, Ecuador. Food and Agriculture Organization of the United Nations, Rome, 10. Available at: http://www.fao.org/3/a-az203s.pdf.

82 Refers to the ancestral territory of the Shuar indigenous communities (see Naturaleza y Cultura Internacional. 2010. "Reserva de Biosfera Podocarpus: El Cóndor." Available at: http://www.naturalezaycultura.org/spanish/htm/ecuador/ areas-andes-podocarpus.htm), which include the El Kiim, Kurints, and Washikiat (see Naturaleza y Cultura Internacional. 2010. "Culturas ancestrales y conservación de bosques nativos." Available at: http://www.naturalezaycultura.org/spanish/ htm/ecuador/areas-amazon-shuar.htm).

83 Refers to Ancestral Territories of Indigenous Peoples, Afro-Ecuadorians, and Montubios. Calculated as the area of collective property under the Socio Bosque Program, minus the area of Socio Bosque contracts within protected areas. The present data refers to native forests preserved in community land and indigenous territories in forests. Data from: Sistema Único de Información Ambiental. 2017. Mapa Interactivo Ambiental. Available at: http://mapainteractivo. ambiente.gob.ec/portal/.

${ }^{84}$ Calculated as total forest area minus the forest area "designated for Indigenous Peoples and local communities." Data on total forest area from: Woody Biomass Inventory and Strategic Planning Project (WBISPP). As cited by FAO. 2014n. Global Forest Resources Assessment 2015, Country Report, Ethiopia. Rome, 10. Available at: http://www.fao.org/3/aaz209e.pdf.

${ }^{85}$ Calculated as total forest area minus the forest area "designated for Indigenous Peoples and local communities." Data on total forest area from: Woody Biomass Inventory and Strategic Planning Project (WBISPP). As cited by FAO 2014n: 10.

86 Refers to Participatory Forest Management User Groups. Data from: Kubsa, Abdurahiman, Asfaw Mariame, Girma Amante, Hans-J Lipp and Tsegaye Tadesse. 2002. "WAIIB: An Alternative Forest Conservation Approach for Ethiopia's Forests." Food and Agriculture Organization of the United Nations, Rome. Accessed June 13, 2018. Available at: http:// www.fao.org/docrep/ARTICLE/WFC/XII/0145-C2.HTM

87 Refers to Participatory Forest Management User Groups and Communal Land Holdings in Forest Areas. Data on Participatory Forest Management User Groups is based on a partial sample of the country. Winberg, Ellen. 2011. Participatory Forest Management in Ethiopia, Practices and Experiences. Food and Agriculture Organization of the United Nations, Rome, 9. Available at: http://www.fao.org/3/a-aq407e.pdf. No data on the extent of Communal Land Holdings in Forest Areas is available.

${ }^{88}$ Calculated as total public forest area on forestry lands (METLA 2003), minus the area of the Åland Islands that is under public ownership (calculated at 10.5 percent of the forest area in Åland as of 1997). "Other public ownership" is defined as including Metsähallitus, municipalities, state organizations, parishes, and associations such as jointly owned forests. Data on public forest area from: METLA. 2003. Forest Finland in Brief. Finish Forest Research Institute (FFRI), Vantaa, Finland, 35. Available at: http://www.metla.fi/metinfo/tilasto/julkaisut/muut/brief2003.pdf. No data on the extent of Sámi Forest Rights and Reindeer Herding Rights within "government administered" forestry lands is available.

${ }^{89}$ Calculated as total forestry area minus forestry area "privately owned by individuals and firms" and forestry area in the Åland Islands (also known as Ahvenanmaa) under private ownership, owned by companies, and publicly owned by others. Data on "government administered" forest area is inclusive of forestry land that is owned by the state (defined as "Metsahallitus and other state organizations") in all regions and owned by others (defined as municipalities, parishes, and associations, where "associations" consist of co-operatives, jointly owned forests, limited partnerships, housing companies, and foundations) in all regions except for Åland. The basis for including the state-owned area of Åland in the area that is classified as "government administered" is Section 61 of the Act on Autonomy of Aland (1994/1144). Legislation cited: Government of Finland. 1991. Act on the Autonomy of Åland (1994/1144), as amended through January 2004. August 16, 1991. Article 61. Available at: https://www.finlex.fi/fi/laki/kaannokset/1991/en19911144.pdf. Data on area of Forestry Lands from: Finnish Forest Research Institute. 2014. Statistical Yearbook of Forestry 2014. Natural Resources Institute Finland, 52. Available at: http://www.metla.fi/metinfo/tilasto/julkaisut/vsk/2014/index.html. No data on the extent of Sámi Forest Rights and Reindeer Herding Rights within "government administered" forestry lands is available.

90 Refers to Local Community Ownership of the Åland Islands. Data from: Statistics and Research Åland (ASUB). 2003. Statistical Yearbook of Åland 2003. Statistics and Research Åland (ÅSUB), 72. Available at: http://www.asub.ax/sites/www. asub.ax/files/attachments/page/statistisk_arsbok_for_aland_2003.pdf.

91 Refers to Local Community Ownership of the Åland Islands. Data includes forestry area in the Alland Islands (also known as Ahvenanmaa) under private ownership, owned by companies, and publicly owned by others, as presented in Table 1.6 of the Statistical Yearbook of Forestry 2014: 52. State-owned forestry areas in Åland are not included in calculations under category 3 ("owned by Indigenous Peoples and local communities"). Instead, state-owned forestry areas in Åland are included under "government administered" forest area. Legislation cited: Government of Finland. 
92 Calculated as total forest area privately owned by both industrial and non-industrial owners, minus the area of the Alland Islands that is under private and company ownership (calculated as 89.5 percent of the forest area in Alland as of 1997). Data from: METLA 2003: 35.

93 Calculated as the sum of forestry land that is owned privately (defined as including "non-industrial, private forest owners, heirs, private firms, etc.") and by companies (defined as including "limited companies and their pension foundations, excluding housing companies") according to the 11th National Forest Inventory, minus the area of forestry land that is owned privately and by companies in the Aland Islands (also known as Ahvenanmaa), as presented in Table 1.6. of Finnish Forest Research Institute 2014: 52.

94 All forests were under government administration as of 2002. Data for total forest area from: FAO. 20140. Global Forest Resources Assessment 2015, Country Report, Gabon. Food and Agriculture Organization of the United Nations, Rome, 7. Available at: http://www.fao.org/3/a-az217f.pdf.

95 Calculated as total forest area minus the forest area "designated for Indigenous Peoples and local communities," and includes areas where neighboring populations may exercise their rights of customary use under Article 257 of the Gabonese Forest Code. Data for total forest area from: FAO 20140: 7. Legislation cited: Government of Gabon. 2001. Loi No. 016-01 portant code forestier en République gabonaise. December 31, 2001. Available at: http://extwprlegs1.fao.org/ docs/pdf/gab29255.pdf.

96 Refers to Forêts Communautaires (Community Forests) and Contrat de Gestion de Terroir aux Parcs Nationaux (Management Contract with Local National Parks Administration). Although the establishment of Community Forests have been legally possible since 2001 based on the Gabonese Forest Code, the first two Community Forests were approved in 2013. According to the source cited, as of January 31, 2017, 16 Community Forests with a definitive agreements covered an area of 74,981 ha. In addition, 24 Community Forests under allocation with provisional agreement covered 91,135 ha. Data from: Government of Gabon. 2017. Bilan Sur Les Forets Communautaires. 2. Contrat de Gestion de Terroir aux Parcs Nationaux were further defined in 2017 by Ordonnance No. 007/PR/2017 portant modification et suppression de certaines dispositions de la loi No. 003/2007 du 27 aout 2007 relative aux parcs nationaux which established the rights that allow this CBTR to be reclassified as "designated for Indigenous Peoples and local communities." No area data is available for this CBTR. Legislation cited: Government of Gabon. 2017. Ordonnance No. 007/PR/2017 du 27 février 2007 portant modification et suppression de certaines dispositions de la loi No. 003/2007 du 27 août 2007 relative aux parcs nationaux. Available at: http://www.fao.org/faolex/results/details/en/c/LEXFAOC169251/.

${ }^{97}$ Calculated as total forest area minus the area "designated for Indigenous Peoples and local communities." Data for total forest area from: FAO. 2014p. Global Forest Resources Assessment 2015, Country Report, Gambia. Food and Agriculture Organization of the United Nations, Rome, 10. Available at: http://www.fao.org/3/a-az218e.pdf.

98 Calculated as total forest area minus the area "designated for Indigenous Peoples and local communities." Data for total forest area from FAO 2014p: 10.

99 Refers to Community Forests, Jointly Managed Forest Parks, and Preliminary Community Forest Management Agreement. Data for Community Forests from: Dampha, Almami. 2001. Management of Forest Fires Through the Involvement of Local Communities: The Gambia. Forestry Department, Banjul. As cited by FAO. 2003. Community-based fire management: Case studies from China, The Gambia, Honduras, India, the Lao People's Democratic Republic and Turkey. Food and Agriculture Organization of the United Nations, Rome. (as cited by Sunderlin et al. 2008)

100 Refers to Community Forests, Jointly Managed Forest Parks, and Preliminary Community Forest Management Agreement. Data for Community Forest and Jointly Managed Forest Parks from: Jaiteh, Muhammed. 2016. Gambia Case Study: Prepared for FAO as part of the State of the World's Forests 2016 (SOFO). Food and Agriculture Organization of the United Nations, Rome, 13. Available at: http://www.fao.org/3/a-c0182e.pdf.

101 Camara, Kanimang and Almami Dampha. 2006. Trends in forest ownership, forest resource tenure and institutional arrangements: are they contributing to better forest management and poverty reduction? Case study from the Gambia. Food and Agriculture Organization of the United Nations, Rome. Available at: http://www.fao.org/forestry/12503-0fdfof82 6a4c03974e944c29588cb2ae5.pdf.

102 Data represents the sum of Private Natural Forests and Private Plantation Forests. Data from: Jaiteh 2016.

103 Calculated as total forest area minus the area "designated for Indigenous Peoples and local communities," "owned by Indigenous Peoples and local communities," and "privately owned by individuals and firms." Data for total forest area from: FAO. 2014q. Evaluación de los Recursos Forestales Mundiales 2015, Informe Nacional, Guatemala. Food and 
Agriculture Organization of the United Nations, Rome, 14. Available at: http://www.fao.org/3/az228s.pdf.

104 Refers to the approximate area of Concesiones Comunitarias (Community Concessions) in the Petén region. Data from: FAO. 2002-2003. Inventario Forestal Nacional de Guatemala. And Escobedo, Mario. 2004. Estudio para la estimación de la oferta potencial de materia prima de los bosques certificados de Guatemala. As cited by FAO. 2006a. "FAO Forest Tenure Matrix: Guatemala." Food and Agriculture Organization of the United Nations, Rome, Accessed November 27, 2013. Available at: http://www.fao.org/forestry/download/17092-0600d866b13c5e89c699d4adb6fd95 dd5.pdf.

105 Refers to Concesiones Comunitarias (Community Concessions). Data from: Asociación de Comunidades Forestales de Petén (ACOFOP) and Programa Regional de Investigación sobre Desarrollo y Medio Ambiente (PRISMA). 2017. Evaluando la efectividad del control y prevención de incendios forestales en la Reserva de la Biósfera Maya. Asociación de Comunidades Forestales de Petan and Programa Regional de Investigación sobre Desarrollo y Medio Ambiente. 3. Available at: http://www.acofop.org/descarga/Estudio-ACOFOP-PRISMA.pdf.

106 Refers to Tierras Comunales (Communal Lands). Data from: Instituto Nacional de Bosques (INAB). 2002. Bosques comunales y municipales: Proyecto de fortalecimiento forestal municipal y comunal (BOSCOM). Government of Guatemala. As cited by Elías, Silvel, Brenda García, Carmen Cigarroa, and Violeta Reyna. 2009. Diagnóstico de la conservación y manejo de recursos naturales en tierras comunales. Grupo Promotor de Tierras Comunales, 42. Available at: http://www.conap.gob.gt/Documentos/Pueblos/Diagnostico.pdf.

107 Refers to Tierras Comunales (Communal Lands). Calculated as the total area of Tierras Comunales minus the area of Concesiones Comunitarias presented in INAB 2012. Data from: Instituto Nacional de Bosques (INAB) and Instituto de Agricultura, Recursos Naturales y Ambiente de la Universidad Rafael Landívar (IARNA-URL). 2012. Primer Informe Nacional sobre el Estado de los Recursos Genéticos Forestales en Guatemala. INAB, 46. Available at: https://www.url.edu. gt/publicacionesurl/FileCS.ashx?ld=40187.

108 FAO 2002-2003. And Escobedo 2004, as cited by FAO 2006.

109 All forest were government administered as of 2002. Prior to the enactment of the Amerindian Act of 2006 in 2010, communities did not have sufficiently robust rights for the associated forests to be considered as "designated for Indigenous Peoples and local communities." Data for total forest area from: FAO. 2014r. Global Forest Resources Assessment 2015, Country Report, Guyana. Food and Agriculture Organization of the United Nations, Rome, 10. Available at: http://www.fao.org/3/a-az232e.pdf.

110 Calculated as total area minus the area "designated for Indigenous Peoples and local communities." Data for total forest area from: FAO 2014r: 10.

111 Refers to Titled Amerindian Village Land, Community Forest Management Agreements, and Amerindian Protected Areas. Data for Titled Amerindian Village Land from: Guyana Forestry Commission. 2018. Guyana REDD+ Monitoring Reporting \& Verification System (MRVS): Year 6 Summary Report - Final, 1 January 2015 to 31 December 2016. Guyana Forestry Commission and Indufor Asia Pacific. Available at: http://www.forestry.gov.gy/wp-content/ uploads/2018/05/MRVS-Summary-Report-Year-6.pdf. Data for Community Forest Management Agreements from: Guyana Forestry Commission. 2016. Summary of Allocation of State Forest Authorizations and Community Forest Management Agreements. Available at: http://www.forestry.gov.gy/wp-content/uploads/2016/04/Summary-of-SFAand-CFMA-April-2016.pdf. An agreement has been signed between the Konashen Village Council, the Commission, and Conservation International which may lead to the establishment of the first Amerindian Protected Area in Guyana; however, the Minister had yet to issue a Declaration Order or publish a formal notice in the Gazette as of November 2017. Therefore, the "625,000 ha of pristine rainforest" covered by the Agreement have not been included in calculations. Data from: Palmer, John. 2017. Personal communication, Forest Management Trust, Senior Associate. November 6, 2017; Radzick, Vanda. 2017. Personal communication, Independent Consultant. November 7, 2017; Stabroek News. 2017. Konashen to be declared a National Protected Area, July 13. Accessed June 5, 2018. Available at: https://www. stabroeknews.com/2017/news/guyana/07/13/konashen-to-be-declared-a-national-protected-area/; The REDD desk. 2018. Konashen Community-Owned Conservation Area. Accessed June 5, 2018. Available at: https://theredddesk.org/ countries/initiatives/konashen-community-owned-conservation-area.

112 FAO 2014r: 70.

113 FAO. 2005a. Evaluación de los Recursos Forestales Mundiales 2005, Informe Nacional, Honduras. Food and Agriculture Organization of the United Nations, Rome, 10. Available at: http://www.fao.org/tempref/docrep/fao/010/ ai861S/ai861S00.pdf.

114 Calculated as total forest area minus the area "designated for Indigenous Peoples and local communities," "owned 
by Indigenous Peoples and local communities," and "privately owned by individuals and firms." Data for total forest area calculated as 47.72 percent of total surface area in Honduras based on: Instituto Nacional de Conservación y Desarrollo Forestal, Áreas Protegidas y Vida Silvestre-ICF (National Institute of Conservation and Forest Development, Protected Areas and Wildlife). 2017. Resultados de la Evaluación Nacional Forestal de Honduras, Proyecto de Modernización del Sector Forestal de Honduras (MOSEF). EuroFor MOSEF, Tegucigalpa, 26-27.

115 Refers to Contratos de Manejo (Management Contracts). Of this area, 0.558916 mha overlaps with national forests, and 0.03768685 mha overlaps with Ejidal forests. Data from: Instituto Nacional de Conservación y Desarrollo Forestal, Áreas Protegidas y Vida Silvestre-ICF (Honduran National Institute of Conservation and Forest Development, Protected Areas and Wildlife-ICF). 2016. Anuario Estadístico Forestal de Honduras 2015. Honduran National Institute of Conservation and Forest Development, Protected Areas and Wildlife, 71. Available at: http://icf.gob.hn/wp-content/ uploads/2017/04/CIPF-Anuario-Forestal-de-Honduras-2015.pdf.

116 Refers to Privado Tribal. Before the enactment of the 2004 Property Law, the National Agrarian Institute (INA) had previously titled the land of other indigenous communities using provisions in the 1985 Agrarian Reform Law and 1992 Agrarian Transformation Law. However, this analysis was unable to determine whether titles issued as of 2002 included forest areas.

117 Refers to Privado Tribal and Miskito Coastal Communities. Data for Privado Tribal calculated as 2.9 percent of total forest area, based on: ICF 2017:34. Although "[t]here is no official data for forest areas in indigenous territories, ... just the Muskitia holds almost 20\% of all the forests in the country (ICF 2014)" and most land areas owned by Indigenous Peoples are understood to be forested. As cited by Forest Trends. 2015. Titling Ancestral Territories in the Honduran Muskitia: Exploring the Implications for the Country's Indigenous Peoples. Forest Trends, 8-9. Available at: https://www.forest-trends.org/wp-content/uploads/imported/honduras-brief_english_a4_final-pdf.pdf. Data for Miskito Coastal Communities calculated as the total area of Intercommunity Titles issued to the Miskitu by both the INA and ICF from 2012-2016 (according to Alvarez et al. 2017), plus the area of titles issued by the INA to the Garifuna, Lenca, Maya-Chorti, Pech, Tawahka, and Tolupan as of 2015 (according to Forest Trends 2015), plus the area of Intercommunity Titles issued to the Pech by ICF from 2012-2016 (according to Alvarez et al. 2017), minus the area of Concejo Territorial de Bakinasta (according to Alvarez et al. 2017, which is noted in Forest Trends 2015 (endnote 4) as being included in the figures in that publication). Data from: Alvarez, Roman, Enrique Pantoja, Gerson Granados, and Alain Paz. 2017. Strengthening Indigenous Peoples Land Rights in Honduras: The Miskitu People's Experience of Collective Land titling, Lessons Learned and Main Challenges for the Future. Paper prepared for presentation at the 2017 World Bank Conference on Land and Poverty. The World Bank, Washington, DC, March 20-24, 2017; Forest Trends 2015.

118 FAO 2005a.

119 Calculated as 33.6 percent of total forest area. ICF 2017: 34.

120 Calculated as total forest area minus the area "owned by Indigenous Peoples and local communities" and "privately owned by individuals and firms." Data for total forest area from: FAO. 2014s. Global Forest Resources Assessment 2015, Country Report, India. Food and Agriculture Organization of the United Nations, Rome, 74-75. Available at: http://www. fao.org/3/a-az238e.pdf.

121 Calculated as total forest area minus the area "owned by Indigenous Peoples and local communities" and "privately owned by individuals and firms." Data for total forest area from: Forest Survey of India. 2015. India State of Forests Report. Ministry of Environment and Forests, Dehradun, 43. Available at: http://fsi.nic.in/isfr-2015/isfr-2015-forest-cover. pdf.

122 See Box 2.

123 Refers to Scheduled Tribes and Other Traditional Forest Dwellers Land. Forest area reported in this source pertains specifically to areas with Community Forest Resource Rights (CFRs) that have been legally recognized at a subnationallevel, as required by the Forest Rights Act. The report "has excluded estimates for Jammu \& Kashmir, Arunachal Pradesh, Manipur, Nagaland, Mizoram and Meghalaya. The five north-eastern states are excluded because of lack of reliable data while Jammu \& Kashmir was excluded as the Act is not applicable in the state yet." In the past, data regarding forest area that is "owned by Indigenous Peoples and local communities" in India has relied on data provided by India's Ministry of Tribal Affairs (MoTA). For the methodological reasons articulated in Promise and Performance, RRI no longer relies upon this data as it is not the most precise data source available. Citizens' Report as part of Community Forest Rights-Learning and Advocacy (CFR-LA). 2016. Promise \& Performance: Ten Years of the Forest Rights Act in India. CFR-LA, India, 9-10. Available at: http://rightsandresources.org/wp-content/uploads/2016/12/Promise-and-Performance-10-Years-of-theForest-Rights-Act-in-India_December-2016_Community-Forest-Rights.pdf. 
125 FAO 2014s: 74-75.

126 Total forest area presented in the Global Forest Resources Assessment Country Report for Indonesia represents forested areas both within and outside legally classified "forestland." Data on total forest area from: FAO 2014t. Global Forest Resources Assessment 2015, Country Report, Indonesia. Food and Agriculture Organization of the United Nations, Rome, 16. Available at: http://www.fao.org/3/a-az239e.pdf.

127 Calculated as total forest area minus the area "designated for Indigenous Peoples and local communities" and "privately owned by individuals and firms."

128 Calculated as total forest area minus the area "designated for Indigenous Peoples and local communities," "owned by Indigenous Peoples and local communities," and "privately owned by individuals and firms."

129 Refers to Hutan Kemasyarakatan (HKm) (Rural or Community Forestry). Data for 2002 reflects the area of Hutan Kemasyarakatan (HKm) located in "production and protection forests," and is not disaggregated between HKm that have received "work permits" (IUPHKm) and forest areas where communities have not received "work permits" (PAK HKm). Calculated as the total area of "community forests" in 2003 as reported by the Ministry of Forestry, Republic of Indonesia, and published in FAO 2006b (Forest Tenure Matrix: Indonesia), minus the area of HKm established in 2003 as published in Table III.7.1 of Statistik Kehutanan Indonesia 2007. Data from: FAO 2006b. As cited by Dahal, Ganga Ram, Julian Atkinson and James Bampton. 2011. Forest Tenure in Asia: Status and Trends. The European Union Forest Law Enforcement, Governance and Trade Facility, Kuala Lumpur. Available at: https://dlc.dlib.indiana.edu/dlc/bitstream/ handle/10535/7719/doc_2721.pdf?sequence=1\&isAllowed=y; Ministry of Forestry. 2008. Statistik Kehutanan Indonesia (Forestry Statistics of Indonesia) 2007. Jakarta, 105. Available at: http://www.storage.jak-stik.ac.id/ProdukHukum/ kehutanan/Stat_2007.pdf.

130 Refers to Hutan Kemasyarakatan (HKm) (Rural or Community Forestry), Hutan Tanaman Rakyat (HTR) (People Plantation or People Plant Forest), Hutan Desa (HD) (Village Forest), and Hak Komunal (Communal Rights). Data included in calculations of HKm, HTR, and HD for 2017 includes only the area of social forestry where "work permits" have been issued (IUPHKm, IUPHH-HTR, and HPHD). Data from: Daryanto, Hadi. 2017. Shared Learning Social Forestry in Indonesia as Access Tenure Reform [Slide 3]. Presentation to World Bank Land and Poverty Conference 2017, Washington, DC.

131 Refers to Hutan Adat (Customary Law Forest). Hutan Adat has been reclassified as "owned by Indigenous Peoples and local communities" on the basis of Constitutional Court Ruling No. 35/2013 and Ministerial Regulation No. $32 / 2015$. Legislation cited: Government of Indonesia. 2013. Constitutional Court, PUTUSAN - Nomor 35/PUU-X/2012; Ministry of Environment and Forestry (MOEF). 2015. Ministerial Regulation No. P.32/Menlhk-Setjen/2015. Article 10. Data refers to the full recognition of four Adat communities as of December 2016, as well as the Hutan Adat recognized in forest areas in 2017. Data from: Gindroz, Anne-Sophie. 2018. Personal communication, Southeast Asia Regional Facilitator, Rights and Resources Initiative, March 6, 2018.

132 Refers to Hutan Rakyat (Private Forest), calculated as the total area of "private" forest in 2003 as reported by the Ministry of Forestry, Republic of Indonesia and published in FAO 2006b (Forest Tenure Matrix: Indonesia), minus the area of Hutan Rakyat in 2003 as published in Table III.3.1 of Statistik Kehutanan Indonesia 2007. Data from: Ministry of Forestry, Republic of Indonesia. As cited by FAO 2006b; Ministry of Forestry 2008: 85; see also Dahal et al. 2011.

133 Refers to Hutan Rakyat (Private Forest). Calculated as the total area of "private" forest in 2003 reported by the Ministry of Forestry, Republic of Indonesia, and published in FAO 2006b (Forest Tenure Matrix: Indonesia), plus the area of Hutan Rakyat in 2004 as published in Table III.3.1 of Statistik Kehutanan Indonesia 2007; plus the area of Hutan Rakyat for 2005, 2006, 2007, 2008, and 2009 as published in Table III.3.1 of Statistik 2009; plus the area of Hutan Rakyat for 2010 and 2011 as published in Table 5.2.3.1 of Statistik 2014; plus the area of Hutan Rakyat in 2012-2016 as published in Graph 3.3 of Statistik 2016. Data from: Ministry of Forestry, Republic of Indonesia. As cited by FAO 2006b; Ministry of Forestry 2008: 85; Ministry of Forestry. Statistik. 2009; Ministry of Environment and Forestry. 2015. Statistik Kementerian Lingkungan Hidup dan Kehutanan Tahun 2014. Jakarta, 227. Available at: http://www.menlhk.go.id/downlot. php?file=STATISTIK_2014.pdf; Ministry of Environment and Forestry. 2017. Statistik Lingkungan Hidup dan Kehutanan Tahun 2016. Jakarta, 135. Available at: http://www.menlhk.go.id/downlot.php?file=Statistik_KLHK_2016.pdf.

134 Refers to national forests and public forests (including prefectural forest, municipal bodies, and property wards). Data from: Japanese Forestry Agency. As cited by FAO. 2014u. Global Forest Resources Assessment 2015, Country Report, Japan. Food and Agriculture Organization of the United Nations, Rome, 85. Available at: http://www.fao.org/3/aaz247e.pdf.

135 Refers to national forests and public forests (including prefectural forest, municipal bodies and property wards). 
Data covers the forests defined in Article 2 of the Forest Act. Data from: The Census of Agriculture and Forestry. As cited by Ministry of Agriculture, Forestry and Fisheries (MAFF). "90th Statistical Yearbook of Ministry of Agriculture, Forestry and Fisheries [Statistical Table XI, 3.2.b: Forest Land Area]." MAFF. Accessed October 16, 2017. Available at: http://www.maff. go.jp/e/data/stat/90th/attach/xls/index-361.xls.

136 Refers to aggregated data for Collectively-Owned Forests (including Forest Owners/Producers' Cooperatives, Authorized Neighborhood Associations, and legally recognized "rights of common"). Data from: 2000 World Census of agriculture and Forestry in Japan. As cited by Yamashita, Utako 2017. Personal communication, University of Tokyo, November 17, 2017.

137 Refers to aggregated data for Collectively-Owned Forests (including Forest Owners/Producers' Cooperatives, Authorized Neighborhood Associations, and legally recognized "rights of common"). Data from: Statistics on Forestry Cooperatives in 2015. As cited by Yamashita 2017.

138 Calculated as total private forest area minus the area of Collectively-Owned Forests. Data on total private forest area from: Japanese Forestry Agency. As cited by FAO 2014u: 85.

139 Calculated as total private forest area minus the area of Collectively-Owned Forests. Data on total private forest area from: The Census of Agriculture and Forestry. As cited by Ministry of Agriculture, Forestry and Fisheries (MAFF).

140 Calculated as total forest area minus the area "privately owned by individuals and firms." Data for total forest area from: FAO. 2014v. Global Forest Resources Assessment 2015, Country Report, Kenya. Food and Agriculture Organization of the United Nations, Rome, 72. Available at: http://www.fao.org/3/a-az251e.pdf.

141 Refers to the total area of 39 Community Forest Associations with approved Forest Management Plans and signed Forest Management Agreements that were originally recognized under the 2005 Forest Act and remain in force, and are to be revised in accordance with the 2016 Forest Conservation and Management Act. Legislation cited: Government of Kenya. 2016. The Forest Conservation and Management Act, 2016 (No. 34 of 2016). September 7, 2016. Available at: http://www.fao.org/faolex/results/details/en/c/LEX-FAOC160882; Government of Kenya. 2005. Forests Act, 2005 (Cap. 385). February 1, 2007. Available at: http://www.fao.org/faolex/results/details/en/c/LEX-FAOC064065. Data from: Kenya Forest Service. "Approved Management Plans and Signed FMAs." Kenya Forest Service. Accessed September 24 2017. Available at: http://www.kenyaforestservice.org/documents/pfm/APPROVED\%20MANAGEMENT\%20PLANS\%20 REGISTER\%20with\%20Agreements.pdf.

142 Refers to Registered and Unregistered Community Lands established under the Community Land Act of 2016. No data on the extent of forestlands within Registered and Unregistered Community Lands is available. Legislation cited: Government of Kenya. 2016. The Community Land Act, No. 27 of 2016. September 21, 2016. Available at: http:// kenyalaw.org/kl/fileadmin/pdfdownloads/Acts/CommunityLandAct_27of2016.pdf.

143 FAO 2014v: 73.

144 FAO 2014v: 73.

145 Calculated as the sum of 2000 data for National Forest area and Public Forest area, minus the area "designated for Indigenous Peoples and local communities." Data for National and Public Forest area from: Statistical Yearbook of Forestry. 2000. As cited by FAO. 2014w. Global Forest Resources Assessment 2015, Country Report, Republic of Korea. Food and Agriculture Organization of the United Nations, Rome, 99-100. Available at: http://www.fao.org/3/a-az312e.pdf.

146 Calculated as the sum of 2017 data for National Forest area and Public Forest area, minus the area "designated for Indigenous Peoples and local communities." Data for National and Public Forest area from: Korea Forest Service. 2017. The Statistical Yearbook of Forestry 2017. Republic of Korea.

147 Refers to Communities with Forest Protection Agreements and Village Forest Associations. Data for Village Forest Associations from: FAO 2014w: 102.

148 Refers to Communities with Forest Protection Agreements and Village Forest Associations. Data for Village Forest Associations from: FAO 2014w: 102.

149 Statistical Yearbook of Forestry 2000. As cited in FAO 2014w: 99-100.

150 Korea Forest Service 2017.

151 Refers to National Community Property. Data for total forest area from: FAO. 2014x. Global Forest Resources Assessment 2015, Country Report, Lao People's Democratic Republic. Food and Agriculture Organization of the United Nations, Rome, 75. Available at: http://www.fao.org/3/a-az255e.pdf. 
152 Calculated as total forest area minus the area "designated for Indigenous Peoples and local communities." Data for total forest area from: FAO 2014x: 75.

153 Refers to Permanent Titles for Collective Land, Temporary Land Use Certificates for Communal Land, and Village Use Forest. Lands included in these tenure regimes may be referred to as either "Collective" or "Communal" in related literature and legislation. We use the term "Collective" in this analysis to reflect the terminology used in Schneider 2013. Data for Permanent Titles for Collective Land from: Schneider, Tina. 2013. Communal land titles in the Lao PDR: Extracting lessons from pilot initiatives. Deutsche Gesellschaft für Internationale Zusammenarbeit (GIZ) GmbH, Bonn and Eschboorn, 29. Available at: https://www.snrd-asia.org/download/climate_protection_through_avoided_deforestation_ clipad/Schneider-T-CliPAD_Communal-titling-study.pdf. The Temporary Land Use Certificates issued in 2011 expired in 2014, and according to Akiko Inoguchi in 2017, "There is no evidence that the temporary certificates valid for three years were made permanent. Therefore, there is no legal status of these lands at this stage." Inoguchi, Akiko. 2017. Personal communication, Forestry Officer (REDD+), Food and Agriculture Organization of the United Nations, September 8, 2017. No data on the extent of Village Use Forests exists.

154 FAO 2014x: 75.

155 FAO 2014x: 75 .

156 Refers to Community Forests (including Aborigines Grant Deeds, Public Land Deeds, Public Land Sale Deeds, Tribal Land Deed Certificates and Warranty Deeds, and Community Forest Management Agreements). Data on 32 authorized Community Forests with approved Community Forest Management Agreements from: Kaba, Ali. 2018. Personal communication, Senior Researcher and Program Director of the Community Land Protection Program, Sustainable Development Institute. June 3, 2018.

157 The Federal Constitution of Malaysia places forest under the jurisdiction of state governments. Malaysian national law does not recognize community-based forest tenure regimes as defined in this study, nor does it regulate private forest rights held by individuals or firms or forests administered by government bodies. Consequently, no data is available for any of the tenure categories featured in this study, which pertain to forest tenure as legally recognized under national law. Subramaniam, Yogeswaran. 2018. Personal communication, Advocate and Solicitor, February 26, 2018.

158 No area data disaggregating forest under the state domain from forests under legally recognized customary ownership exists for any year covered by this analysis for Mali. Consequently, no data is available for forests that are "government administered" or "owned by Indigenous Peoples and local communities."

159 Refers to le domaine forestier des collectivités territoriales décentralisées (The Forest Domain of Decentralized Territorial Collectives). Despite having passed laws permitting the decentralization of forests in 1996, no land has been transferred under the authority of "collectivités territoriales." Legislation cited: Government of Mali. 1996. Loi No. 96-050, portant principes de constitution et de gestion du domaine de collectivités territoriales. October 16, 1996. Available at: http://www.fao.org/faolex/results/details/en/c/LEX-FAOC013824. Data from: FAO. 2014y. Evaluation des Ressources Forestières Mondiales 2015, Rapport National, Mali. Food and Agriculture Organization of the United Nations, Rome, 70. Available at: http://www.fao.org/3/a-az268f.pdf.

160 Refers to The Forest Domain of Decentralized Territorial Collectives (Le domaine forestier des collectivités territoriales décentralisées). Despite having passed laws permitting the decentralization of forests in 1996, no land has been transferred under the authority of "collectivités territoriales." Legislation cited: Government of Mali 1996. Data from: FAO 2014y: 70.

161 FAO 2014y: 71.

162 FAO 2014y: 71.

163 All data for 2002 from: El Subsector Forestal en México. 1998. Consejo Técnico Consultivo Nacional Forestal. As cited by White and Martin 2002. All data for 2017 from: INEGI 2007. As cited by FAO. 2010b. Evaluación de los Recursos Forestales Mundiales 2010, Informe Nacional, México. Informe Nacional 132. Food and Agriculture Organization of the United Nations, Rome, 22. Available at: http://www.fao.org/docrep/013/al567S/al567S.pdf. Data for forest area "owned by Indigenous Peoples and local communities" refers to Ejidos Localizados en Tierras Forestales (Ejidos located on Forestlands) and Comunidades (Communities).

164 As of 2002, all forests were under government administration. Data on total forest area from: Forest Research and Development Center, MET. As cited by Ulambayar, Tungalag. 2017. Personal communication, October 25, 2017.

165 Calculated as total forest area minus the area "designated for Indigenous Peoples and local communities." Data on 
total forest area from: Forest Research and Development Center, MET. As cited by Ulambayar 2017.

166 Refers to 1,281 Community Forest User Groups. Data from: Department of Forest Policy and Coordination, MET. As cited by Ulambayar 2017.

167 Direito de uso e aproveitamento da terra (DUAT) (Rights of use and benefit of land) do not legally need to be formalized nor proven in order to be actionable under the law. Communities may choose to formalize these rights through a process of community land delimitation which culminates in the issuance of a certificate provided by the state, or through a request by a community to the state for a Community Land Title, a process which involves demarcation. Data exists on the extent of these delimited and demarcated rights, but that would grossly underestimate the total legal area owned by communities.

168 Refers to Forest Concessions to Communities and Zones with Historical Culture Use and Value. Data on Forest Concessions to Communities refers to one DUAT that is managed and operational as a forestry concession in Macossa District in Manica Province, from: Nhantumbo and Izidine. 2009. As cited by Mcqueen, Duncan and Mário Falcão. 2017. Reforço da governação florestal em Moçambique. Opções para a promoção de uma exploração florestal mais sustentável entre comerciantes de madeira chineses e os seus parceiros moçambicanos. IIED, 41. Available at: http:// pubs.iied.org/pdfs/17601PIIED.pdf.

169 Calculated as total forest area minus the area "designated for Indigenous Peoples and local communities." Data on total forest area from: Central Statistical Organization. "Statistical Data: Forest Cover Status in Myanmar, Data Updated on: 2017-07-12/Term: Annual 1996-2014." Accessed May 9, 2018. Available at: http://mmsis.gov.mm/statHtml/statHtml. do?orgld=195\&tblld=DT_YAF_0003\&conn_path=12.

170 Calculated as total forest area minus the area "designated for Indigenous Peoples and local communities." Data on total forest area from: FAO. 2014z. Global Forest Resources Assessment 2015, Country Report, Myanmar. Food and Agriculture Organization of the United Nations, Rome, 9. Available at: http://www.fao.org/3/a-az283e.pdf.

171 Refers to Community Forest Concessions and Village-Owned Firewood Plantations on Reserved Forests or Protected Public Forests. Village-Owned Firewood Plantations on Reserved Forests or Protected Public Forests were identified as an additional Community-Based Tenure Regime during 2016 when a Depth of Rights and Gender analysis was first conducted for Myanmar. Data on Community Forest Concessions from: Community Forest Unit. 2017a. As cited by Aung Kyaw Naing, Community Forestry Partnerships Officer, RECOFTC Myanmar. Personal communication, September 19, 2017.

172 Refers to Community Forest Concessions and Village-Owned Firewood Plantations on Reserved Forests or Protected Public Forests. Data on Community Forest Concessions from: Community Forest Unit. 2017b. Presentation at the 11th Community Forestry National Working Group (CFNWG) Meeting, June 12. As provided in personal communication with Aung Kyaw Naing, Community Forestry Partnerships Officer, RECOFTC Myanmar, September 19, 2017.

173 Calculated as total forest area minus the area "designated for Indigenous Peoples and local communities" and "privately owned by individuals and firms." Data on total forest area includes both Forests and Other Wooded Lands, from: Ministry of Forests and Soil Conservation, Government of Nepal. As cited in FAO. 2014aa. Global Forest Resources Assessment 2015, Country Report, Nepal. Food and Agriculture Organization of the United Nations, Rome, 11. Available at: http://www.fao.org/3/a-az286e.pdf.

174 Calculated as total forest area minus the area "designated for Indigenous Peoples and local communities" and "privately owned by individuals and firms." Data on total forest area includes both Forests and Other Wooded Lands, from: Department of Forest Research and Survey, Ministry of Forests and Soil Conservation. 2015. State of Nepal's Forests: Forest Resources Assessment (FRA) Nepal. Government of Nepal, Kathmandu, 25. Available at: http://www.dfrs. gov.np/downloadfile/State\%20of\%20Nepals\%20Forests\%20(DFRS)_1457599484.pdf.

175 Refers to Buffer Religious Forest Handed over to a Community, Buffer Zone Community Forest, Community Forest, Community Leasehold Forest, and Religious Forest Handed over to Communities. Data for Buffer Zone Community Forests includes all Buffer Zones established prior to December 2002. Area for Makalu Barun National Park Buffer Zone is not included because the data does not disaggregate by year. Data from: GoN/DNPWC 2012. Annual Report (2011/2012). Government of Nepal and Department of National Parks and Wildlife Conservation, Kathmandu, Annex 11. Data on Community Forests from: Mahat, Anupama. 2011. Forest Tenure in Nepal: Status and Trends. Draft Report, Kathmandu, 8. Prepared as input to Dahal, Ganga Ram and Adhikari, Krishna. 2011. South Asia Forest Tenure Assessment. Helvetas Swiss Intercooperation, Latipur. Data on Community Leasehold Forests from: HMGN/MFSC. 2002. Nepal Biodiversity Strategy. Ministry of Forests and Soil Conservation and His Majesty's Government of Nepal, Kathmandu, 49. Available at: http://www.cbd.int/doc/world/np/np-nbsap-01-en.pdf. The first instance of a Buffer Zone 
Religious Forest Handed over to a Community occurred in 2009.

176 Refers to Buffer Religious Forest Handed over to a community, Buffer Zone Community Forest, Community Forest, Community Leasehold Forest, Religious Forest Handed over to Communities, and Collaborative Forests. Data on Buffer Religious Forest Handed over to a Community from: GoN/DNPWC 2012: Annex 11; Paudel, Naya Sharma, 2017. Personal communication, ForestAction Nepal, August 25, 2017. Data for Buffer Zone Community Forest, Community Leasehold Forests, and Collaborative Forests from: Department of Forests. 2017. Hamro Ban. As cited by Paudel, Naya Sharma, 2017. Data for Community Forests from: Department of Forests, Community Forestry Division. Community Forestry Bulletin \#17. Fiscal year 2016/17. Kathmandu, Nepal. As cited by Raj Kanel, Keshav. 2017. Personal communication, August 27, 2017; Department of Forests 2017. As cited by Paudel 2017. Data for Religious Forest Handed over to Communities from: HMG, Ministry of Finance. 2017. Economic survey 2016-2017, Kathmandu, Nepal. As cited by Raj Kanel 2017. Department of Forests 2017. As cited by Paudel 2017.

177 HMGN/MFSC. 2002. Nepal Biodiversity Strategy. Ministry of Forests and Soil Conservation and His Majesty's Government of Nepal, Kathmandu, 52. Available at: http://www.cbd.int/doc/world/np/np-nbsap-01-en.pdf.

178 HMG, Ministry of Finance 2017. As cited by Raj Kanel 2017. Department of Forests. 2017. As cited by Paudel 2017.

179 The Preamble and Article 1 of the Land Use Act of 1978 irrevocably vests all lands in the governor of each state. As such, no forest is recognized as privately owned or administered by the government at the national level. However, the law does recognize customary rights of occupancy, thereby providing a legal framework recognizing limited communitybased rights at the national level. See Federation of Nigeria. 1978. Land Use Act 1978. March 29, 1978. Available at: http://urbanlex.unhabitat.org/sites/default/files/urbanlex/land_use_act_1978_0.pdf.

180 Calculated as total forest area minus the area "designated for Indigenous Peoples and local communities." Data on total forest area from: FAO. 2010c. Global Forest Resources Assessment, Country Report, Nigeria. Country Report 151. Food and Agriculture Organization of the United Nations, Rome, 11. Available at: http://www.fao.org/docrep/013/al586E/ al586E.pdf.

181 Refers to Community Forests in Cross River State. Data from: CRS Forestry Commission Data. 2001. As cited by Oyebo, Macarthy, Francis Bisong, and Tunde Morakinyo. 2010. A Preliminary Assessment of the Context of REDD in Nigeria. Federal Ministry of Environment, Cross River State's Forestry Commission and United Nation Development Program, Cross River State, Nigeria, 20.

182 Calculated as total forest area minus the area "designated for Indigenous Peoples and local communities," "owned by Indigenous Peoples and local communities," and "owned by individuals and firms." Data for total forest area from: FAO. 2014bb. Evaluación de los Recursos Forestales Mundiales, Informe Nacional, Panamá. Food and Agriculture Organization of the United Nations, Rome, 11. Available at: http://www.fao.org/3/a-az302s.pdf.

183 Calculated as total forest area minus the area "designated for Indigenous Peoples and local communities," "owned by Indigenous Peoples and local communities," and "owned by Individuals and firms." Data for total forest area from: FAO 2014bb: 11.

184 Refers to Territorio de los Pueblos Indígenas incluyendo las Comarcas y las Tierras Colectivas (Indigenous Peoples' Territories including Comarcas and Collective Lands). This CBTR is understood to be inclusive of both Comarcas and Collective Lands established under Law 72 of 2008. For additional information, see: Rights and Resources Initiative 2017 (endnote xii). Forest-specific data as of 2000 was identified for the provincial-level Comarcas of Kuna Yala, EmberáWounaan, and Ngobe-Bugle. Data from: National Forestry Development and Administration Service (Servicio Nacional de Desarrollo y Administración Forestal - ANAM). 2003. Panama. SIF-ANAM/OIMT-2000 Project, report on forest cover 1992-2000. As cited by García, Marcial Arias. Forests, Indigenous Peoples and Forestry Policy in Panama: an assessment of national implementation of international standards and commitments on traditional forest related knowledge and forest related issues. 7. Available at: http://www.binal.ac.pa/panal/downloads/fipdoc.pdf.

185 Refers to Territorio de los Pueblos Indígenas incluyendo las Comarcas y las Tierras Colectivas. This CBTR is understood to be inclusive of both Comarcas and Collective Lands established under Law 72 of 2008 For additional information, see: Rights and Resources Initiative 2017 (endnote xii). Forest-specific data as of 2000 was identified for the provincial-level Comarcas of Kuna Yala, Emberá-Wounaan, and Ngobe-Bugle. Data from: National Forestry Development and Administration Service (Servicio Nacional de Desarrollo y Administración Forestal - ANAM) 2003. As cited by García: 7.

186 FAO 2014bb: 95.

187 FAO 2014bb: 95. 
188 Calculated as 3 percent of total forest area. Data on total forest area from: FAO. 2010d. Global Forest Resources Assessment 2010, Country Report, Papua New Guinea. Country Report 161. Food and Agriculture Organization of the United Nations, Rome, 14. Available at: http://www.fao.org/docrep/013/al596E/al596e.pdf.

189 Calculated as 3 percent of total forest area. Data on total forest area from: Bryan, J.E., and Phil L. Shearman (Eds). 2015. The State of the Forests of Papua New Guinea 2014: Measuring Change over period 2002-2014. University of Papua New Guinea, Port Moresby. Available at: http://www.bioticregulation.ru/common/pdf/png.pdf.

190 Refers to Common Customary Land (referenced in Rights and Resources Initiative 2015 as Tribal Land). Calculated as 97 percent of total forest area in accordance with the method used by the government to report in FAO 2010d, minus the area of forests "privately owned by individuals and firms."

191 Refers to Common Customary Land (referenced in Rights and Resources Initiative 2015 as Tribal Land). Calculated as 97 percent of total forest area in accordance with the method used by the government to report in FAO 2010d, minus the area of forests "privately owned by individuals and firms."

192 In previous analyses, RRI did not identify any forest area as "privately owned by individuals and firms" in Papua New Guinea. However, private forest ownership of individuals and firms is legally possible. See: Government of Papua New Guinea. 1975. Constitution of the Independent State of Papua New Guinea (with amendments) (hereinafter, "Constitution of Papua New Guinea"). September 15, 1975. Art. 56. Available at: http://www.fao.org/faolex/results/details/en/c/LEXFAOC132625; and Government of Papua New Guinea. 1964. Land (Ownership of Freeholds) Act of 1976 (Law No. 76 of 1976) (hereinafter, "Land Act of 1976"). February 20, 1964. Art. 4. Available at: http://www.fao.org/faolex/results/details/ en/c/LEX-FAOC052080. Data from: FAO. 2014cc. Global Forest Resources Assessment 2015, Country Report, Papua New Guinea. Food and Agriculture Organization of the United Nations, Rome, 76. Available at: http://www.fao.org/3/a-az303e. pdf.

193 In previous analyses, RRI did not identify any forest area "privately owned by individuals and firms" in Papua New Guinea. However, private forest ownership of individuals and firms is legally possible. See: Government of Papua New Guinea. 1975. Constitution of Papua New Guinea; Government of Papua New Guinea. 1964. Land Act of 1976. Data from: FAO 2014cc: 76.

194 Calculated as total forest area minus the area "designated for Indigenous Peoples and local communities," "owned by Indigenous Peoples and local communities," and "privately owned by individuals and firms." Data on total forest area from: FAO. 2014dd. Evaluación de los Recursos Forestales Mundiales, Informe Nacional, Perú. Food and Agriculture Organization of the United Nations, Rome, 53. Available at: http://www.fao.org/3/a-az305s.pdf.

195 Calculated as total forest area minus the area "designated for Indigenous Peoples and local communities," "owned by Indigenous Peoples and local communities," and "privately owned by individuals and firms." Data on total forest area from: MINAM. 2016. Primer Informe Parcial del Inventario Nacional Forestal y de Fauna Silvestre. Lima, 16. Available at: http://sinia.minam.gob.pe/documentos/primer-informe-parcial-inventario-nacional-forestal-fauna-silvestre.

196 Refers to Reservas Territoriales (Territorial Reserves). Data on Reservas Territoriales were established between 1990 and 2003, and are intended by Decreto Supremo MIMDES No. 008/2007 to be converted to Reservas Indígenas. Data from: National Forest Authority ("Autoridad Nacional Forestal"). 2000. as cited in: FAO. 2010e. Evaluación de los Recursos Forestales Mundiales 2010, Informe Nacional, Perú. Country Report 163. Food and Agriculture Organization of the United Nations, Rome, 22. Available at: http://www.fao.org/docrep/013/al598S/al598S.pdf.

197 Refers to Reservas Territoriales and Reservas Indígenas (Indigenous Reserves and Territorial Reserves) and Reservas Comunales en Suelo Forestal (Communal Reserves in Forest Land). Data for Reservas Territoriales and Reservas Indígenas from IBC. 2009. "Mapa Amazonía Peruana 2009." Instituto del Bien Común (IBC), Lima; Galvez, Alfredo. Personal communication, Lawyer, Sociedad Peruana de Derecho Ambiental (SPDA). August 31, 2017. Data for Reservas Comunales en Suelo Forestal from: Government of Peru. SERNANP. 2017. Sistema de Áreas Naturales Protegidas del Perú. Available at: http://www.sernanp.gob.pe/documents/10181/165150/Lista_Pagina_Web_OFICIAL_2017-06-08.pdf/ a00d48ab-5349-4e8c-b62f-68e2ace4c3b6.

198 Refers to Tierras de Comunidades Campesinas con Aptitud Forestal (Peasant Community Forest Lands Suitable for Forestry) and Tierras de Comunidades Nativas con Aptitud Forestal. Data on Comunidades Nativas con Aptitud Forestal from: National Forest Authority ("Autoridad Nacional Forestal"). 2000. As cited by FAO 2010e: 163.

199 Refers to Tierras de Comunidades Campesinas con Aptitud Forestal (Peasant Community Forest Lands Suitable for Forestry) and Tierras de Comunidades Nativas con Aptitud Forestal (Native Community Forest Lands Suitable for Forestry). All data from: FAO 2014dd: 151.

200 Data for 2002 refers to Predios Privadas and may not be entirely forested. FAO. 2005b. Global Forest Resources Assessment, Peru Country Report. Country Report 201, Food and Agriculture Organization of the United Nations, Rome, 29. Available at: http://www.fao.org/tempref/docrep/fao/010/ai931S/ai931s00.pdf. 
202 Total Forest Area refers to "forestlands," which are legally defined as including "the public forest, the permanent forest or forest reserves, and forest reserves" in Art. 3(d) of the Revised Forestry Code of the Philippines, Presidential Decree No. 705. This area includes both classified and unclassified forestlands. Notably, this area is significantly larger than the forest cover reported for the Philippines in both the Global Forest Resources Assessment Country Report for the Philippines and the Philippine Forest Statistics reports, but because data for CBFMAs, PACBRMAs, CALTs, and CADTs is understood to represent areas within legal "forestlands," we have used this figure rather than forest cover for consistency. Data for total forest area of legal forestlands for all years from: National Mapping and Resource Information Authority (NAMRIA). As cited by Department of Environment and Natural Resources, Forest Management Bureau. 2016. 2016 Philippine Forestry Statistics. Department of Environment and Natural Resources, Forest Management Bureau, Republic of the Philippines. Available at: https://drive.google.com/file/d/0B1G5mTNoDPOFSTgzVEjicm50V2s/ view? usp=sharing.

203 Calculated as total area of legal forestlands minus the area "designated for Indigenous Peoples and local communities" and "owned by Indigenous Peoples and local communities."

204 Calculated as total area of legal forestlands minus the area "designated for Indigenous Peoples and local communities" and "owned by Indigenous Peoples and local communities."

205 Refers to Community-Based Forest Management Agreements (CBFMAs). Data from: Department of Environment and Natural Resources (DENR) 2000. As cited by Guiang, Ernesto S., Salve B. Borlagdan, and Juan M. Pulhin. 2001. Community-Based Forest Management in the Philippines: A Preliminary Assessment. Institute of Philippine Culture, Quezon City, 13. Available at: http://dlc.dlib.indiana.edu/dlc/bitstream/handle/10535/7541/CBFM\%20Preliminary\%20 Assessment.pdf?sequence=1.

206 Refers to Community-Based Forest Management Agreements (CBFMAs) and Protected Area Community Based Resource Management Agreements (PACBRMAs). Data for CBFMAs from: Department of Environment and Natural Resources, Forest Management Bureau. 2017. Philippine Forests at a Glance: 2017 Edition. Department of Environment and Natural Resources, Republic of the Philippines, 12. Available at: http://online.anyflip.com/mjyy/auj//mobile/index. html\#p=2. Data for PACBRMAs from: Philippines Forestry Statistics. 2011. As cited by Eleazar, Floradema C., Brian Garcia, Ernie Guiang, Annabelle Herrera, Lina D. Isorena, Roel Ravanera and Ernesto Serote. 2013. Improving Land Sector Governance in the Philippines: Implementation of Land Governance Assessment Framework (LGAF), Revised Draft Report. Department of Environment and Natural Resources, Republic of the Philippines and the World Bank, 42. Available at: http://siteresources.worldbank.org/INTLGA/Resources/Philippines_Final_Report.pdf.

207 Refers to Certificates of Ancestral Domain Title (CADTs) and Certificates of Ancestral Land Title (CALTS). No CALTS had been issued as of 2002. Data from Philippine Partnership for the Development of Human Resources in Rural Areas (PhilDHRRA). 2011. Systematizing Access to Land Monitoring in the Philippines: Monograph. Asian NGO Coalition for Agrarian Reform and Rural Development (ANGOC) and International Land Coalition (ILC), 22. Available at: http://i. phildhrra.net/application/files/1214/7928/5606/PhilDHRRA_access_to_land_monitoring_report_monograph-1.pdf.

208 Refers to Certificates of Ancestral Domain Title (CADTs) and Certificates of Ancestral Land Title (CALTs). According to Eleazar et al. 2013, "Most of the country's ancestral domains are located within forest lands," and data for CALTs refers to approved CALTs in forestlands. Data for CADTs from: Republic of the Philippines, National Commission on Indigenous Peoples, Ancestral Domains Office. Provided by Maguigad, Edna. 2015. Personal communication, Lawyer, April 17, 2015. Data for CALTs from: Philippines Forestry Statistics 2011. As cited by Eleazar et al. 2013: 42, 53.

209 Calculated as total forest area minus the area "designated for Indigenous Peoples and local communities" and "privately owned by individuals and firms" and includes the area of Reserves Communautaires (Community Reserves) (which specifically relates to the Lac Télé Reserve). Notably, in past RRI reports, Reserves Communautaires were classified as "designated for Indigenous Peoples and local communities." However, peer review feedback in 2017 indicated that communities are not managing the site, nor do they have a right to participate in management. Venisnik, Tanja. 2018. Personal communication, ClientEarth, April 25, 2018; Counsell, Simon. 2018. Personal communication, Rainforest UK, March 12, 2018. Data on total forest area from: FAO. 2014ee. Evaluation des Ressources Forestières Mondiales 2015, Rapport National, Congo. Food and Agricultural Organization of the United Nations, Rome, 16. Available at: http://www. fao.org/3/a-az189f.pdf.

210 Calculated as total forest area minus the area "designated for Indigenous Peoples and local communities" and "privately owned by individuals and firms" and includes area of Reserves Communautaires (Community Reserves) (which specifically relates to the Lac Télé Reserve). Notably, in past RRI reports, this CBTR was classified as "designated for Indigenous Peoples and local communities." However, peer review feedback in 2017 indicated that communities are not managing the site, nor do they have a right to participate in management. Venisnik 2018; Counsell 2018. Data on total forest area from: FAO 2014ee: 16. 
211 Refers to Forêts des communes et autres Collectivités Locales dans laquelle les droits d'usage sont reconnue (Forests of Communities and Other Local Collectives with Recognized Use Rights). Government of the Republic of the Congo and FAO. 2014. La politique forestie de la republique du Congo (2014 - 2025). Government of the Republic of the Congo and Food and Agricultural Organization of the United Nations, 31. Available at: http://extwprlegs1.fao.org/docs/ pdf/con143403.pdf.

212 Refers to Forêts des communes et autres Collectivités Locales dans laquelle les droits d'usage sont reconnue (Forests of Communities and Other Local Collectives with Recognized Use Rights) and Les terres des Peuples Autochtones (Indigenous Populations' Land). Data for Forêts des communes et autres Collectivités Locales dans laquelle les droits d'usage sont reconnue (Forests of Communities and Other Local Collectives) from: Government of the Republic of the Congo and FAO 2014: 31 Les terres des Peuples Autochtones (Indigenous Populations' Land) was legally established in 2011, but implementing legislation has yet to be enacted. FERN. 2017. Étude diagnostique sur la foresterie communautaire en République du Congo: Project de collaboration d'ONG en faveur de moyens de subsistance communautaires équitables et durables dans les forêts du bassin du Congo. FERN, Brussels. Available at: http://www. fern.org/sites/fern.org/files/ferrn\%20roc\%202017.pdf.

213 FAO 2014ee: 84.

214 FAO 2014ee: 84.

215 All forests in the Russian Federation legally remain under government administration. Data on total forest area from: FAO. 2014ff. Global Forest Resources Assessment 2015, Country Report, Russia. Food and Agriculture Organization of the United Nations, Rome. Available at: http://www.fao.org/3/a-az316e.pdf.

216 Calculated as the forest area for Droits d'usage des populations riveraines dans le domaine forestier de l'état (Usage Rights of Riparian Populations in the Forest Domain of the State), plus the forest area for Droits d'usage des populations riveraines dans les forêts gérées par les collectivités locales (Usage Rights of Riparian Populations in Forests Managed by Local Collectives). Data from: FAO. 2014gg. Evaluation des Ressources Forestières mondiales 2015, Rapport National, Sénégal. Food and Agriculture Organization of the United Nations, Rome, 110. Available at: http://www.fao.org/3/az329f. pdf.

217 Calculated as the forest area for Droits d'usage des populations riveraines dans le domaine forestier de l'état (Usage Rights of Riparian Populations in the Forest Domain of the State), plus the forest area for Droits d'usage des populations riveraines dans les forêts gérées par les collectivités locales (Usage Rights of Riparian Populations in Forests Managed by Local Collectives). Data from: FAO 2014gg: 17, 59 and 110.

218 Refers to Les forêts communautaires avec des droits de gestion légalement reconnus (Community Forests with Legally Recognized Management Rights). Data from: FAO 2014gg: 108.

219 Prior to the passing of the most recent decentralization law (Loi No. 2013-10 du 28 décembre 2013 portant Code général des collectivités locales) in December 2013, Senegalese national law permitted local communities to exercise management rights over their forests through rural councils, which were community-based management bodies integrated within the local decentralized forest management system of "collectivités locales." See Loi No. 96-07 du mars 1996, portant transfert de compétences aux régions, aux communes et aux communautés rurales. Loi No. 2013-10 transferred the community-based management rights of rural councils to township-level administrative bodies that are not community-based entities (see articles 293 and 329). Thus, as of January 2014, no CBTRs classified as "designated for Indigenous Peoples and local communities" exist under Senegalese law. Legislation cited: Government of Senegal. 2013. Loi No. 2013-10 du 28 décembre 2013 portant code général des collectivités locales. December 28, 2013. Available at: http://www.au-senegal.com/IMG/pdf/code_general6119.pdf; Government of Senegal. 1996. Loi No. 96-07 du mars 1996, portant transfert de compétences aux régions, aux communes et aux communautés rurales. Available at: http://www. servicepublic.gouv.sn/assets/textes/loi-transfert-region.pdf.

220 FAO 2014gg: 109.

221 FAO 2014gg: 110.

222 No data is presented for 2002 because South Sudan became an independent country in 2011. It has not been methodologically possible to disaggregate between the forest area of Sudan and South Sudan; as a result, 2017 data on the forest area that is "government administered," "designated for Indigenous Peoples," and "owned by Indigenous Peoples" is not available for South Sudan. Data on total forest area used in calculations throughout this report refers to the forest area of Sudan prior to the independence of South Sudan. Data from: FAO. 2010f. Global Forest Resources Assessment 2010, Country Report, Sudan. Food and Agriculture Organization of the United Nations, Rome, 8. Available at: http://www.fao.org/docrep/013/al633E/al633E.pdf.

223 "Although the Land Act recognizes freehold as a valid form of ownership, there is currently no land held in freehold anywhere in South Sudan." Data from: Deng, David K. 2014. South Sudan Country Report: Findings of the Land 
224 It has not been methodologically possible to disaggregate between the forest area of Sudan and South Sudan; as a result, 2017 data on the forest area that is "government administered," "owned by Indigenous Peoples and local communities," and "privately owned by individuals and firms" is not available for Sudan. Data on total forest area used in calculations throughout this report refers to the forest area of Sudan prior to the independence of South Sudan. Data from: FAO 2010f: 8.

225 Refers to Participatory Management of Reserved Areas and Community Forests (Social Forests). Data for Participatory Management of Reserved Areas from: Nori, Wafa Mohamed Tahir. 2012. Detection of land cover changes in El Rawashda forest, Sudan: A systematic comparison. Dissertation. Technische Universität Dresden, Dresden, 34-35. Available at: http://www.qucosa.de/fileadmin/data/qucosa/documents/9561/Wafa_Nori_Thesis.pdf; Kobbail, Amani Abdel Rahim, Abdelhai Mohamed Elmadina, and Mahir Salih Sulieman. 2005. Management of Natural Forest Reserves in Collaboration with Villagers: A Case Study of Rawashda and Elain Natural Forests in Sudan. Sudan Journal of Desertification Research 4 (1): 8, 12. Available at: http://sustech.edu/staff_publications/20120921165239411.pdf. No data is available for Community Forests.

226 Refers to Participatory Management of Reserved Areas and Community Forest (Social Forest). Data for Participatory Management of Reserved Areas from: Nori, Wafa Mohamed Tahir. 2012. Detection of land cover changes in El Rawashda forest, Sudan: A systematic comparison. Dissertation. Technische Universität Dresden, 34-35. Available at: http://www. qucosa.de/fileadmin/data/qucosa/documents/9561/Wafa_Nori_Thesis.pdf; Kobbail, Elmadina, and Sulieman 2005: 8 and 12. Data for Community Forest (Social Forest) from: Hassan and Tag Consultants 2018. In-depth Analysis of Drivers of Deforestation and Forest/Range Degradation. Hassan and Tag Consultants, Khartoum, 41.

227 Calculated as total forest area minus the area "privately owned by individuals and firms," and includes Gemeenschapsbos (Community Forests) and Houtkapvergunning (Communal Timber Cutting Licenses). Notably, these CBTRs were classified as "designated for Indigenous Peoples and local communities" in What Future for Reform (Rights and Resources Initiative 2014). However, based on peer review feedback for Who Owns the World's Land (Rights and Resources Initiative, 2015), these areas were reclassified as "government administered." Under the Forest Management Act of 1992, communities may have limited rights of access and withdrawal where "Gemeenschapsbos" are designated by the Minister, but the "utilization and management of communal forests" has not been determined by decree as called for by Art. 41(3), nor do communities have rights to exclude outsiders from these areas. Legislation cited: Government of Suriname. 1992. Forest Management Act, No. 80 of 1992. September 18, 1992. Available at: https://www.elaw.org/sites/ default/files/content_type_law_attachment/Forest\%20Management\%20Act\%201992.pdf. Data on total forest area from: FAO. 2014hh. Global Forest Resources Assessment 2015, Country Report, Suriname. Food and Agriculture Organization of the United Nations, Rome, 11. Available at: http://www.fao.org/3/a-az343e.pdf.

228 Calculated as total forest area minus the area "privately owned by individuals and firms," and includes Gemeenschapsbos (Community Forests) and Houtkapvergunning (Communal Timber Cutting Licenses). See note above. Data on total forest area from: Government of Suriname, Ministerie Van Ruimtelijke Ordening Grond-En Bosbeheer. 2017. Surinaamse Bosbouwsector 2016: Stichting voor Bosbenheer en Bostoezicht, 2. Available at: http://sbbsur.com/ wp-content/uploads/2018/02/Rapport-Bosbouw-Sector-2016.pdf.

229 FAO 2014hh: 78.

230 FAO 2014hh: 78.

231 Notably, Statistical Yearbook of Forestry reports published by the Swedish Forest Agency through 2013 only published forest ownership data for productive forestlands, and as a result previous RRI reports reported only the area of productive forests as total forest area. However, the 2014 Swedish Statistical Yearbook of Forestry Data contains data on ownership of both productive and non-productive forests, and total forest area published in the 2015 FAO Global Forest Resources Assessment Country Report for Sweden contains both productive and "lowproductive" forest. Therefore, data on "government administered" forests and forests "privately owned by individuals and firms," as well as total forest area, for 2002, has been retroactively adjusted in accordance with the 2015 FRA. Data on total forest area from: FAO. 2014ii. Global Forest Resources Assessment 2015, Country Report, Sweden. Food and Agriculture Organization of the United Nations, Rome, 11 and 28.

232 Refers to areas under "public ownership" as of 2000. Data from: FAO 2014ii: 73.

233 Calculated as total public forest area minus the area "designated for Indigenous Peoples and local communities." Data from: FACESMAP. 2015. Enquiry on Forest Ownership in the ECE Region. As cited by Lidestav, Gun. 2017. Personal communication, Swedish University of Agricultural Sciences, November 21, 2017; Christiansen, Linn. 2017. Personal communication, Skogsstyrelsen, December 6, 2017.

234 Refers to Indigenous Co-management of Laponia tjuottjudus (Laponia World Heritage Site). Calculated as the sum 
of mountain birch forest and coniferous forest areas in Sarek National Park, Padjelanta/Badjelánnda National Park, Stora Sjöfallet/Stuor Muorkke National Park, Muddus/Muttos National Park, Sjávnja Nature Reserve, Stubbá Nature Reserve, Ráhpaäno suorgudahka (the Lájtávrre delta), Tjuoldavuobme, and Sulidälbmá as reported in the 2014 Tjuottjudusplána Management Plan for the Laponia World Heritage Site. Data from: UNESCO. 2014. Laponia: World Heritage in Swedish Lapland. Tjuottjudusplána Management Plan. Available at: https://laponia.nu/wp-content/uploads/2014/08/Laponiaforvaltningsplan-eng-web-150327_2.pdf.

235 Refers to Forest Commons. Calsson. Lars. 1995. Skogsallmänningarna i Sverige. As cited by Holmgren, Eva. 2009. Forest Commons in Boreal Sweden, Doctoral Thesis. Swedish University of Agricultural Sciences, Umeå, 28.

236 Refers to Forest Commons. FACESMAP 2015. As cited by Lidestav 2017.

237 Calculated as total private forest area minus the area "owned by Indigenous Peoples and local communities." Data on private forest area from: FAO 2014ii: 73.

238 Calculated as total private forest area minus the area "owned by Indigenous Peoples and local communities." Data on private forest area from: FACESMAP 2015. As cited by Christiansen 2017.

239 In What Future for Reform (Rights and Resources Initiative 2014), Village Land Forest Reserves, Non-Reserved Forests on Village Lands, Community Forest Reserves, and Wildlife Management Areas were classified as "designated for Indigenous Peoples and local communities." These CBTRs have been reclassified as "owned by Indigenous Peoples and local communities" based on additional feedback from peer reviewers, clarifying that communities under all four CBTRS legally possess rights of exclusion. Alden Wiley, Liz. 2018. Personal communication, Independent Expert, January 9, 2018. See also: Government of Tanzania. 1999. Village Land Act. Available at: http://www.fao.org/faolex/results/details/en/c/LEXFAOC053306.

240 Calculated as total forest area minus the area "designated for Indigenous Peoples and local communities," "owned by Indigenous Peoples and local communities," and "privately owned by individuals and firms." Data on total forest area from: Ministry of Natural Resources and Tourism. As cited by FAO. 2014jj. Global Forest Resources Assessment 2015, Country Report, Tanzania. Food and Agriculture Organization of the United Nations, Rome, 77. Available at: http://www. fao.org/3/a-az366e.pdf.

241 Calculated as total forest area minus the area "designated for Indigenous Peoples and local communities, "owned by Indigenous Peoples and local communities," and "privately owned by individuals and firms." Data on total forest area from: Ministry of Natural Resources and Tourism, Tanzania Forest Services (TFS) Agency. 2015. NAFORMA: National Forest Resources Monitoring and Assessment of Tanzania Main Results. Government of the United Republic of Tanzania, Government of Finland, and Food and Agriculture Organization of the United Nations, Dar es Salaam, v. Available at: http://www.tfs.go.tz/uploads/NAFORMA_REPORT.pdf.

242 Refers to Joint Forest Management. Data from: Masayanyika, S.W. and J.S. Mgoo 2001. Basic Assessment of Benefits and Costs Sharing and Other Issues Affecting Joint Forest Management (JFM) and Community-Based Forest Management (CBFM). Ministry of Natural Resources and Tourism, Forestry and Beekeeping Division, Dar es Salaam. As cited by Meshack, Charles, Bhim Ahdikari, Nike Doggart, and Jon C. Lovett. 2006. Transaction Costs of Community-Based Forest Management: Empirical Evidence from Tanzania. African Journal of Ecology 44 (4): 2.

243 Refers to Joint Forest Management. Data from: Ministry of Natural Resources and Tourism. 2012. Participatory Forest Management in Tanzania: Facts and Figures. The United Republic of Tanzania, Dar es Salaam. Available at: http:// www.tfs.go.tz/uploads/Facts_and_Figures.pdf.

244 Refers to Village Land Forest Reserves, Non-Reserved Forests on Village Lands, and Community Forest Reserves. Data for Non-Reserved Forests on Village Lands from: Interview Notes with (Haki Ardhi, Ministry of Lands, MNRT) and Blomley \& Said Iddi. 2009 as cited by Caldecott, J. B., P. Killian, P. Tommila, M. Halonen Rinne, and L. Oja. 2013. Scoping Mission for a Possible Renewable Natural Resource Economic Governance Programme in Tanzania. Gaia Consulting Oy, Helsinki, Finland. As cited by Rights and Resources Initiative 2014. No data is available for Village Land Forest Reserves and Community Forest Reserves.

245 Refers to Village Land Forest Reserves, Non-Reserved Forests on Village Lands, Community Forest Reserves, and Wildlife Management Areas. Data for Community Forest Reserves relates to 41 villages in the Districts of Lindi, Kilwa, Lilwale, Ruangwa, Natumbo, and Tunduru as of June 2017. Kilahama, Felician. 2017. Personal communication, November 15, 2017. Data for Non-Reserved Forests on Village Lands from: Ministry of Natural Resources and Tourism, Tanzania Forest Services (TFS) Agency 2015: 40. Data for Village Land Forest Reserves from: Ministry of Natural Resources and Tourism 2012: 4. Data for Wildlife Management Area from: WWF. 2014. Tanzania's Wildlife Management Areas: A 2012 Status Report. World Wildlife Fund, Dar es Salaam, 7. Available at: http://www.twma.co.tz/uploads/WMA_Status_ Report_2012_Final.pdf.

246 Ministry of Natural Resources and Tourism as cited by FAO 2014j: 76. 
248 Calculated as total forest area minus the area "designated for Indigenous Peoples and local communities." Data on total forest area from: Government of Thailand, Office of Forest Land Management. Table 1: Total Forest Area 1973 2016. Accessed June 18, 2018. Available at: http://forestinfo.forest.go.th/Content/file/stat2559/Table\%201.pdf.

249 Calculated as total forest area minus the area "designated for Indigenous Peoples and local communities." Data on total forest area from: Government of Thailand 2018.

250 Refers to Allocated Community Title (based on Constitutional Community Rights) and Community Land Title Deeds. Data for Allocated Community Title (based on Constitutional Community Rights) from: Royal Forestry Department. 2015. As cited by Rattanakrajangsri, Kittisak. 2015. Personal communication, Indigenous Peoples Foundation for Education and Environment (IPF). February 28, 2015. The "Community Land Title Deeds" CBTR was previously published as "Community Land Use Permits," but has been retitled in order to be consistent with the Regulation of the Prime Minister's Office on the Issuance of Community Land Title Deeds (See endnote xvii of the 2017 RRI report Power and Potential). Data for Community Land Title Deeds refers to data for Khlong Yong and Mae Awe. Data for Khlong Yong from: Prasertpholkrang, Jeerapong. 2011. "Villagers Get Communal Land Title Deeds." The Nation. Accessed July 1, 2015. Available at: http:// www.nationmultimedia.com/2011/02/13/national/Villagers-get-communal-land-title-deeds-30148576.html. Data for Mae Awe from: Office of the Permanent Secretary of the Prime Minister. As cited by Onprom, Surin. 2015. Personal communication, Lecturer, Forest Management Department, Faculty of Forestry, Kasetsart University. July 1, 2015.

251 Private ownership of forest plantations-excluding rubber plantations, which do not fall within the legally recognized forest estate-is legally possible in Thailand. However, because the number of registered forest plantations is understood to be negligible, the area owned by firms and individual is reported as zero. Rattanarat, Warangkana. 2018. Personal communication, RECOFTC, June 25, 2018; Durst, Patrick. 2018. Personal communication, Senior Forestry Officer for Asia and the Pacific, FAO, June 25, 2018. See also Government of Thailand. 1992. Commercial Forest Plantation Act (B.E. 2535). March 1, 1992. Available at: http://www.fao.org/faolex/results/details/en/c/LEX-FAOC070240.

252 Private ownership of forest plantations_excluding rubber plantations, which do not fall within the legally recognized forest estate-is legally possible in Thailand. However, because the number of registered forest plantations is understood to be negligible, the area owned by firms and individual is reported as zero. Rattanarat 2018; Durst 2018. See also Government of Thailand. 2015. Forest Plantation Act (No. 2) of 2015 (B.E. 2558). May 20, 2015. Unofficial translation available at: http://www.krisdika.go.th/wps/wcm/connect/ eeb15f8043c25be3a0f4af49dc260fed/FOREST+PLANTATION+ACT+\%28NO.+2\%29\%2C+B.E.+2558+\%282015\%29. pdf?MOD=AJPERES\&CACHEID=eeb15f8043c25be3a0f4af49dc260fed.

253 Due to the complex and overlapping nature of the Timorese statutory framework, it is not possible to determine the extent to which communities hold legally recognized rights to land, forests, and natural resources at this time. The Constitution of Timor-Leste recognizes customary law to the extent that it does not conflict with the Constitution, and it recognizes individual private property rights. However, it does not specifically recognize communities' customary land or natural resources. Law 10/2011 defines communal property as land customarily shared by the community. Law 1/2003, however, allocates all lands formerly held by the Portuguese government to the government of Timor-Leste. Legislation cited: Government of Timor-Leste. 2002. Constitution of the Democratic Republic of Timor-Leste. May 22, 2002. Available at: http://timor-leste.gov.tl/wp-content/uploads/2010/03/Constitution_RDTL_ENG.pdf; Government of Timor-Leste. 2003. Law 1/2003: The Juridical Regime of Real Estate, Part 1: Ownership over Real Estate. December 24. Available at: http:// timor-leste.gov.tl/wp-content/uploads/2010/03/Law_2003_1_juridical_regime_real_estate_part__.pdf; Government of Timor-Leste. 2004. Decree Law 19/2004. December 29, 2004. Available at: http://mj.gov.tl/jornal/lawsTL/RDTL-Law/ RDTL-Decree-Laws/Decree-Law-2004-19.pdf; Government of Timor-Leste. 2011. Law 10/2011: Approves the Civil Code. September 14, 2011. Available at: http://www.ilo.org/dyn/natlex/docs/ELECTRONIC/89755/111788/F-1268875196/ TMP89755\%20Eng.pdf; Government of Timor-Leste. 2011. Law 27/2011: Regime to Regulate Ownership of Real Estate in Undisputed Cases. July 6, 2011. Available at: http://www.jornal.gov.t//lawsTL/RDTL-Law/RDTL-Decree-Laws/Decree\%20 Law\%2027-2011.pdf; Government of Indonesia. 1991. Indonesian Regulation 18 of 1991. March 13, 1991.

254 FAO. 2014kk. Global Forest Resources Assessment 2015, Country Report, Togo. Food and Agriculture Organization of the United Nations, Rome, 62. Available at: http://www.fao.org/3/a-az353f.pdf.

255 FAO 2014kk.

256 Data disaggregating forests that are "owned by Indigenous Peoples and local communities" from those "privately owned by individuals and firms" is not available.

257 FAO 2014kk: 62.

258 Data disaggregating forests that are "owned by Indigenous Peoples and local communities" from those "privately owned by individuals and firms" is not available. 
259 Calculated as total forest area minus the area "owned by Indigenous Peoples and local communities" and "privately owned by individuals and firms." Data on total forest area from: Smith, Brad, Patrick D Miles, John S. Vissage, Scott A Pugh. 2004. Forest Resources of the United States 2002. U.S. Department of Agriculture, Forest Service, North Central Research Station, St. Paul, 32.

260 Calculated as total forest area minus the area "owned by Indigenous Peoples and local communities" and "privately owned by individuals and firms." Data on total forest area from: Oswalt, Sonja N., W. Brad Smith, Patrick D. Miles, and Scott A. Pugh. 2014. Forest Resources of the United States, 2012: A Technical Document Supporting the Forest Service Update of the 2010 RPA Assessment. WO-91. U.S. Department of Agriculture, Forest Service, Washington Office, Washington, DC, 46.

261 Refers to Indian Reservations (Trust) and Indian Lands (Non-Trust). All data from: United States Bureau of Indian Affairs (BIA). 2002. 2002 Catalog of Forest Acres. United States Department of Interior, Washington DC.

262 Refers to Indian Reservations (Trust) and Indian Lands (Non-Trust). All data from: Indian Forest Management Assessment Team for the Intertribal Timber Council. 2013. Assessment of Indian Forests and Forest Management in the United States, Volume II. Intertribal Timber Council, 224-225. Available at: http://www.itcnet.org/file_download/0fd9804085db-4b11-b05f-3e4c911f68cb.

263 Smith et al. 2004: 32.

264 Oswalt, et al. 2014: 46.

265 All forests were under government administration 2002. FAO. 2014ll. Evaluación de los Recursos Forestales Mundiales 2015, Informe Nacional Venezuela. Food and Agriculture Organization of the United Nations, Rome, 16. Available at: http://www.fao.org/3/a-az372s.pdf.

266 Refers to Hábitat y Tierras de los Pueblos y Comunidades indígenas (Habitat and Land of Indigenous Peoples and Communities within Forest Lands). This CBTR was referred to as "Tierras Indígenas en Áreas Bajo Régimen de Administración Especial (ABRAE) (Indigenous in Special Administration Regime)" in previous RRI reports, but was updated in 2016 based on peer review responses. See Rights and Resources Initiative 2017 (endnote xvii). Research indicates that several titles have been granted to communities through this CBTR. As of March 2013, the titled area was 1,024,348 hectares, but this figure does not disaggregate for forested areas. Data from: SiBCI. 2013. "Etnias indígenas reciben títulos de demarcación de hábitat y tierras, (SIBCI)." SIBCI. Accessed December 3, 2013. Available at: www.vtv.gob.ve/ articulos/2013/03/27/etnias-indigenas-recibentitulos-de-demarcacion-de-habitat-y-tierras-1190.html.

267 All forests were under government administration as of 2002. Data on total forest area from: Ministry of Agriculture and Rural Development of the Socialist Republic of Vietnam. 2002. "Worksheet 2: Forest Area and Forest Land by Type of Management as of December 31, 2002." Ministry of Agriculture and Rural Development of the Socialist Republic of Vietnam. Accessed July 15, 2013. Available at: http://www.kiemlam.org.vn/Desktop.aspx/List/So-lieu-dien-bien-rung-hangnam/. As translated by Nguyen, Quang Tan (RECOFTC - Vietnam Country Program Coordinator).

268 Ministry of Agriculture and Rural Development of the Socialist Republic of Vietnam. 2017. "Decision No. 1819 on the Annual Status of Forests in Vietnam 2016. May 16, 2017." Ministry of Agriculture and Rural Development of the Socialist Republic of Vietnam. Accessed April 24, 2018. Available at: http://www.kiemlam.org.vn/Desktop.aspx/List/So-lieu-dienbien-rung-hang-nam/. As translated by To, Phuc Xuan. (Forest Trends - Senior Policy Analyst, Forest Policy, Trade, and Finance Initiative.)

269 Refers to Forest Land Allocated to Communities. Data from: Ministry of Agriculture and Rural Development of the Socialist Republic of Vietnam 2002.

270 Refers to Forest Land Allocated to Communities. Data from: Ministry of Agriculture and Rural Development of the Socialist Republic of Vietnam 2017.

271 As of 2002, all forests were under government administration. Although Joint Forest Management had been piloted on the basis of Statutory Instrument 52 of 1999, these pilots had reportedly expired by 2002 and the rights accorded to communities through Joint Forest Management remained unclear. Mwitwa, Jacob. 2013. Personal communication, School of Natural Resources, Copperbelt University, Zambia, July 2013. As referenced in endnote 85 of What Future for Reform (Rights and Resources Initiative, 2014). The legal status of Joint Forest Management was further clarified by Statutory Instrument 47 of 2006, but these areas remained classified as "government administered" until the passing of the 2015 Forest Act which articulated community rights under this CBTR. Data on total forest area from: FAO. 2014mm. Global Forest Resources Assessment 2015, Country Report Zambia. Food and Agriculture Organization of the United Nations, Rome, 20. Available at: http://www.fao.org/3/a-az377e.pdf.

272 Calculated as total forest area minus the area "designated for Indigenous Peoples and local communities" and "owned by Indigenous peoples and local communities." Data on total forest area from: FAO 2014mm: 20. The majority of forests classified as "government administered" are likely comprised of customary forest areas, in which communities have recognized rights of access and withdrawal under the 2015 Forest Act. Mwape Sichilongo. 2018. Personal 
communication, World Wildlife Foundation (WWF) Zambia, April 13, 2018.

273 Refers to the area under Joint Forest Management, which has been reclassified as "designated for Indigenous Peoples and Local Communities" with the passage of the 2015 Forest Act. Data from: Government of Zambia, Provincial Forestry Action Programme, as cited by Bwalya, Bridget. 2007. Katanino Joint Forest Management Area, Masaiti District. Zambia: Challenges and Opportunities. Norwegian University of Life Science. Department of International Environmental and Development Studies, 41. Available at: http://www.umb.no/statisk/noragric/publications/master/2007_bridget_ bwalya.pdf.

274 Refers to Community Forests established under the 2015 Forest Act. Data from: Indufor Group. 2017. "Zambia is Moving Ahead in Implementing the New Forest Act and Community Forestry." Indufor Group. Accessed May 7, 2018. Available at: https://induforgroup.com/zambia-is-moving-ahead-in-implementing-the-new-forest-act-and-communityforestry/. 


\section{Box endnotes}

a FAO. 2016c. Forty Years of Community-Based Forestry: A review of its extent and effectiveness. Food and Agriculture Organization of the United Nations, Rome, x. Available at: http://www.fao.org/3/a-i5415e.pdf.

b Between 80 and 90 percent of forest enterprises in many countries are estimated to be of small and medium size. If the informal and formal sectors are considered together, approximately 140 million people are estimated to be employed by such enterprises worldwide. Mayers, James, Lila Buckley, and Duncan Macqueen. 2016. Small, but Many is Big: Challenges in assessing the collective scale of locally controlled forest-linked production and investment. IIED, London, 19. Available at: http://pubs.iied.org/pdfs/16615IIED.pdf.

c While Finland, Japan and the United States all lack formal definitions of "smallholder forest ownership" (or equivalent terms), data is available on the size of forest holdings by range in these three countries, along with Sweden. Data in the U.S. and Japan pertains specifically to family ownerships. Area of family forest ownerships in the U.S. by size of forest holding (in millions of acres) is as follows: $1-9$ acres: 20.07; 10-19 acres: 17.36; 20-49 acres: 43.07; 50-99 acres: 44.25; 100-199 acres: 44.27; 200-499 acres: 43.86; 500-999 acres: 22.12; 1000-4999 acres: 31.13; 5000-9999 acres: 7.86; 10000+ acres: 12.31. Data for the United States from: Butler, Brett. 2018. Personal communication, U.S. Forest Service, July 24, 2018, citing data from: Butler, Brett J., Jaketon H. Hewes, Brenton J. Dickinson, Kyle Andrejczyk, Sarah M. Butler, and Marla Markowski-Lindsay. 2016. Family Forest Ownerships of the United States, 2013: Findings from the USDA Forest Service's National Woodland Owner Survey. Journal of Forestry, 114 (6): 638-647, 643. Available at: https://www. fs.fed.us/nrs/pubs/jrnl/2016/nrs_2016_butler_001.pdf; Data for Finland from: Government of Finland. 2014. Finnish Statistical Yearbook of Forestry 2014. Finnish Forest Research Institute, Finland, 55. Available at: http://www.metla.fi/ metinfo/tilasto/julkaisut/vsk/2014/vsk14_01.pdf; Data for Sweden from: Swedish Forest Agency. 2014. The 2014 Swedish Statistical Yearbook of Forestry. Swedish Forest Agency, Stockholm, 37. Available at: http://klimatetochskogen.nu/ documents/SkS2014-arsboken.pdf; Data for Japan from: Katsuhisa Koroki eds. 2013. Changes in the Forestry Structure and Forestry Management Entities in Japan: Analyses of the 2010 Forestry Census, 30-31, translated by Yamashita, Utako (Faculty of International Agriculture and Food Studies, Tokyo University of Agriculture).

d Cerutti, Paolo Omar, Yustina Artati, Ahmad Dermawan, Alice Kelly, Guillaume Lescuyer, Elena Mejía, Krystof Obidzinski, Pablo Pacheco, Louis Putzel, Raphael Tsanga and Andrew Wardell. 2014. Policy Options for Improved Integration of Domestic Timber Markets under the Voluntary Partnership Agreement (VPA) Regime: Synthesis from lessons learned in Cameroon, the Democratic Republic of the Congo, Ecuador, Gabon and Indonesia. CIFOR Info Brief No. 80. Available at: http://www.cifor.org/publications/pdf_files/infobrief/5079-infobrief.pdf.

e Government of Argentina. Argentina: Plantaciones forestrales y gestión sostenible. Argentinian Ministry of Agriculture, Livestock, and Fisheries, Buenos Aires, 6-7. Available at: http://forestoindustria.magyp.gob.ar/archivos/gestion-forestalsostenible/publi_ambiental.pdf.

f The Forestry Production Direction under Argentina's Ministry of Agriculture, Livestock and Fisheries supports forest plantations and native forest enrichment conducted by individuals and legal persons. It implements Law No. 25.080 of Investments for Planted Forests (as extended and modified by Law N²6.432) and Art. 2 of Law No. 25.080. Government of Argentina. Argentina: Plantaciones forestrales y gestión sostenible. Argentinian Ministry of Agriculture, Livestock, and Fisheries, Buenos Aires, 6-7. Available at: http://forestoindustria.magyp.gob.ar/archivos/gestion-forestal-sostenible/publi_ ambiental.pdf.

g Government of Bhutan. 2007. Land Act of Bhutan. June 27, 2007. Art. 64. Available at: http://www.fao.org/faolex/ results/details/en/c/LEX-FAOC155083.

n Government of Bolivia. 1996. Ley No. 1.715 - Ley de 18 de Octubre de 1996 - Ley del Servicio Nacional de Reforma Agraria (hereinafter, "Ley del Servicio Nacional de Reforma Agraria"). Art. 41(2). Available at: http://www.fao.org/faolex/ results/details/en/c/LEX-FAOC006961.

i Government of Bolivia. 2009. Constitución de 2009 del Estado Plurinacional de Bolivia. February 7, 2009. Art. 394(2). Available at: http://www.wipo.int/edocs/lexdocs/laws/es/bo/bo024es.pdf; Government of Bolivia. 1996. Ley del Servicio Nacional de Reforma Agraria. Art. 41(2). Available at: http://www.fao.org/faolex/results/details/en/c/LEX-FAOC006961.

j Government of Bolivia. 2009. Constitución de 2009 del Estado Plurinacional de Bolivia. February 7, 2009. Art. 394(2). Available at: http://www.wipo.int/edocs/lexdocs/laws/es/bo/bo024es.pdf.

k Government of Brazil. 2012. Lei no. 12.651 de 25 de Maio de 2012. Art. 3(V). Available at: http://www.planalto.gov.br/ ccivil_03/_ato2011-2014/2012/lei/l12651.htm.

I "In British Columbia, the Private Managed Forest Land Act [SBC 2003] provides a management regime for private managed forest lands, and those with an approved plan have reduced land tax rates and are not subject to local government regulations. Private managed forest lands must be minimum a of 25 hectares, and if the land is less than 50 hectares, at least $70 \%$ of the land must be productive. If the land is more than 50 hectares, at least $50 \%$ of the land must be productive. In 2016, the Managed Forest Council in British Columbia stated there were 822,000 hectares of privately 
managed forests in the province. The remaining forests on private land in British Columbia are largely unmanaged forest lands that may be used for multiple values that may not always include timber harvesting." Nikolakis and Powell 2018.

m "In the New Brunswick Forest Products Act (R.S.N.B. 2012, c. 105), "private woodlot" means all forest land except: (a) forest land owned by the Crown; (b) forest land owned by a person whose principal business is the operation of a wood processing facility, unless the main function of the wood processing facility is the production of wood chips and biomass at or on the harvest site; and (c) forest land consisting of an aggregate area of at least 100,000 ha which is owned by the same person or persons. While this statute defines private woodlot, the collection of data on private woodlot owners does not distinguish between corporations and smallholders (families and individuals)." Nikolakis and Powell 2018.

n A 2004 report for Natural Resources Canada defines "woodlot owner" outside of British Colombia as "non-industrial private forests" that "tend to be small in area, often use small-scale management methods, and are normally a stand-alone business not associated with a sawmill or pulpmill." There are distinctions between commercial and noncommercial woodlots in Canadian taxation law. Neave, Erin and Doug Wolthausen. 2004. Private Woodland Owners: Meeting the stewardship challenge. Canadian Model Forest Network, Natural Resources Canada, Ottawa. Available at: http://cfs.nrcan.gc.ca/pubwarehouse/pdfs/25114.pdf. As cited by Nikolakis and Powell 2018.

- Under Canada's Constitution, forests are the jurisdiction of the provinces. Government of Canada. 1982. Constitution Act, 1982. April 17, 1982. Sec. 92A(1). Available at: http://www.fao.org/faolex/results/details/en/c/LEX-FAOC117251. There are no explicit statutory or policy definitions of "smallholder forests ownership" in Canada. However, several definitions applicable to specific provinces were identified and used as proxies to identify smallholder forest area across Canada. Table 2 presents all identified definitions for Canada. The area of Canadian smallholder forest ownership presented in Table 2 represents the aggregate figure across all provinces for which data was available. Area data primarily refers to: Dansereau, Jean-Pierre, and Peter deMarsh. 2003. A Portrait of Canadian Woodlot Owners in 2003. The Forestry Chronicle 79(4), 774-778. Available at: http://pubs.cif-ifc.org/doi/pdf/10.5558/tfc79774-4. In addition, area data refers to: Côté, Marc-André and Vincent Miville. 2017. Ten Arguments Supporting the Granting of an Exemption for Wood from Private Forests in the Future Agreement on Softwood Lumber Exports to the U.S. Canadian Federation of Woodlot Owners. Canadian Federation of Woodlot Owners, Quebec. Available at: http:// www.foretprivee.ca/wp-content/uploads/2017/07/Exemption-for-wood-from-private-forests-in-the-SLA.pdf; Canadian Federation of Woodlot Owners. 2017. "About Us: Canadian Federation of Woodlot Owners." Accessed April 6, 2017. Available at: http://www.cfwo-fcpb.org/about; Personal communication between Nikolakis, William, RRI Consultant, and Côté, Marc-André, Quebec Forest Products Association, January 8, 2018. Forest Nova Scotia. 2015. "About: Forest Nova Scotia." Accessed April 6, 2017. Available at: http://forestns.ca/about/; Neave, Erin and Doug Wolthausen. 2004. Private Woodland Owners: Meeting the stewardship challenge. Canadian Model Forest Network, Natural Resources Canada, Ottawa. Available at: http://cfs.nrcan.gc.ca/pubwarehouse/pdfs/25114.pdf; Statistics Canada. 2015. "Census of Agriculture: Land Use - Table 004-0203." Accessed April 6, 2017. Available at: http://www5.statcan.gc.ca/cansim/ a26?lang=eng\&retrLang=eng\&id=0040203\&paSer=\&pattern=\&stByVal=1 \&p1=1\&p2=1\&tabMode=dataTable\&csid= ; The Private Forest Landowners Association. 2017. "Managed Forest Land." Accessed April 6, 2017. Available at: http:// www.pfla.bc.ca/managed-forest-land/. As cited by Nikolakis and Powell 2018.

p Government of Chile. 2008. Ley No. 20.283 - Ley Sobre Recuperación del Bosque Nativo y Fomento Forestal (hereinafter "Ley No. 20.283"). July 30, 2008. Art. 2(17). Available at: http://extwprlegs1.fao.org/docs/pdf/chi80993. pdf; Government of Chile. 1974. Decreto Ley No. 701 de 1974. October 28, 1974. Art. 2. Available at: http://www.sii.cl/ portales/dj_predios_forestales/decreto_ley_701.pdf.

q Government of Chile. 1974. Decreto Ley No. 701 de 1974. October 28, 1974. Art. 2. Available at: http://www.sii.cl/ portales/dj_predios_forestales/decreto_ley_701.pdf.

r Government of Chile. 2008. Ley No. 20.283. July 30, 2008. Art. 2(17). Available at: http://extwprlegs1.fao.org/docs/pdf/ chi80993.pdf; and Government of Chile. 1974. Decreto Ley No. 701 de 1974. October 28, 1974. Art. 2. Available at: http:// www.sii.cl/portales/dj_predios_forestales/decreto_ley_701.pdf.

s Government of Chile. 2008. Ley No. 20.283. July 30, 2008. Art. 2(17). Available at: http://extwprlegs1.fao.org/docs/pdf/ chi80993.pdf.

t Government of Chile. 2008. Ley No. 20.283. July 30, 2008. Art. 2(17). Available at: http://extwprlegs1.fao.org/docs/pdf/ chi80993.pdf; Government of Chile. 1974. Decreto Ley No. 701 de 1974. October 28, 1974. Art. 2. Available at: http:// www.sii.cl/portales/dj_predios_forestales/decreto_ley_701.pdf.

u Government of Chile. 2008. Ley No. 20.283. July 30, 2008. Art. 2(17). Available at: http://extwprlegs1.fao.org/docs/pdf/ chi80993.pdf; and Government of Chile. 1974. Decreto Ley No. 701 de 1974. October 28, 1974. Art. 2. Available at: http:// www.sii.cl/portales/dj_predios_forestales/decreto_ley_701.pdf.

v Government of Chile. 1974. Decreto Ley No. 701 de 1974. October 28, 1974. Art. 2. Available at: http://www.sii.cl/ portales/dj_predios_forestales/decreto_ley_701.pdf. 
w Based on RRI's understanding of data captured under Category 3 ("Owned by Indigenous Peoples and local communities") in addition to consultation with expert reviewers, RRI does not understand the reported figure for small forest owners to comprise forests held under community-based tenure, even though Chile legally defines "small forest owners" to include indigenous and local communities. Data from: Haddad, Antonio Benedetto and Ingeniero Forestal. 2017. Plantaciones Forestales Efectuadas Durante el Año 2016. Corporación Nacional Forestal (CONAF), Santiago, 13. Available at: http://www.conaf.cl/nuestros-bosques/bosques-en-chile/estadisticas-forestales/. Legislation Cited: Government of Chile. 1974, Art. 2.

x Government of Costa Rica. 1996. Ley No. 7575 - Ley Forestal. 13 February 1996. Art. 2, as amended by Reforma al Reglamento a la Ley Forestal - Decreto Ejecutivo No 25721 - MINAE. October 17, 1996. Available at: http://www.fao.org/ faolex/results/details/en/c/LEX-FAOC009545.

y Government of Mexico. Ley Agraria - Ultimas reformas publicas DOF 27-03-2017. March 27, 2017. Art. 119.

z Barton Bray, David. 2017. Personal communication, Professor at Florida International University, November 2, 2017, citing figures from an unpublished November 2017 database by Instituto Nacional de Investigaciónes Forestales, Agricolas y Pecuarias (INIFAP) and Cento de Investigación y Docencia Económicas A.C. (CIDE) concerning small private property holdings subject to logging management plans between 1990-2010.

aa See definition of "small-scale forestry" and "large-scale forestry" in: Government of Sweden. 2016. Silvicultural Activities in 2016. Swedish Office of Statistics, Sweden, 17. Available at: https://www.skogsstyrelsen.se/globalassets/statistik/ statistiska-meddelanden/atgarder-i-skogsbruket-jo16/sm-atgardsstatistik-i-skogsbruket.pdf.

bb Data pertaining to the area of productive forestland in Sweden held by ownership category is available according to specific ranges. Swedish Forest Agency. The 2014 Swedish Statistical Yearbook of Forestry. Swedish Forest Agency, Stockholm, 37. Available at: http://klimatetochskogen.nu/documents/SkS2014-arsboken.pdf.

« Government of India. 1990. The Circular Concerning Joint Forest Management, No. 6-21/89-P.P. Government of India, New Delhi. Available at: http://www.fao.org/faolex/results/details/en/c/LEX-FAOC021949.

dd Rights and Resources Initiative. 2018. Cornered by Protected Areas: Replacing 'fortress' conservation with rights-based approaches helps bring justice for Indigenous Peoples and local communities, reduces conflict, and enables cost-effective conservation and climate Action. Rights and Resources Initiative, Washington, DC. Available at: https://rightsandresources.org/en/publication/cornered-by-protected-areas/\#.W2Qr5PZuLIU and http://www. corneredbypas.com.

ee African Commission on Human and Peoples' Rights v. Republic of Kenya, Application No. 006/2012. Judgement, May 26, 2017. Available at: http://en.african-court.org/images/Cases/Judgment/Application\%20006-2012\%20 -\%20African\%20Commission\%20on\%20Human\%20and\%20Peoples\%E2\%80\%99\%20Rights\%20v.\%20the\%20 Republic\%20of\%20Kenya.pdf.

ff Amnesty International. 2018. Families Torn Apart: Forced eviction of Indigenous People in Embobut Forest, Kenya. Amnesty International, London. Available at: https://www.amnesty.org/download/Documents/ AFR3283402018ENGLISH.PDF.

gg Forest Peoples Programme. 2018. EU suspends funding to Kenya government over indigenous human rights violations. Forest Peoples Programme. Accessed April 6, 2018. Available at: http://www.forestpeoples.org/en/rightsbased-conservation/press-release/2018/eu-suspends-funding-kenya-government-over-indigenous; Forest Peoples Programme. 2018. Where next for the Sengwer and the EU WaTER Project? Forest Peoples Programme. Accessed April 16, 2018. Available at: http://www.forestpeoples.org/en/node/50266; Delegation of the European Union to Kenya. 2018. Why the EU's support for conservation of Kenya's 'Water Towers' remains suspended. Delegation of the European Union to Kenya. Delegation of the European Union to Kenya. Accessed April 16, 2018. Available at: https://eeas.europa.eu/delegations/kenya/41231/why-eus-support-conservation-kenyas-water-towers-remainssuspended_en.\%20. The violent evictions of the Sengwer resulted in a joint communication directed at both the European Commission and the government of Kenya from three UN Special Rapporteurs in January 2018: United Nationals Human Rights Office of the High Commissioner. 2018. "Indigenous rights must be respected during Kenya climate change project, say UN experts." United Nations Human Rights Office of the High Commissioner. Accessed April 16, 2018. Available at: https://www.ohchr.org/EN/NewsEvents/Pages/DisplayNews.aspx?NewsID=22584.

hh Kenya National Commission on Human Rights (KNCHR). 2018. An Interim Report of the High-Level Independent Fact-Finding Mission to Embobut Forest in Elgeyo Marakwet County: A KNCHR report. KNCHR, Nairobi. Available at: https://eeas.europa.eu/sites/eeas/files/report_knchr__14_june-official_0.pdf.

ii Brownell, Alfred. 2018. Personal communication, Lead Campaigner, Green Advocates, June 27, 2018; Green Advocates, Alliance for Rural Democracy, and Natural Resource Woman Platform. 2018. Commissioning PostFPIC Audit of the Establishment of the Gola and Grebo-Krahn National Parks in Liberia. Unpublished policy memorandum. 
ij International Commission of Jurists, Amnesty International, and Human Rights Watch. 2018. Thailand: Special Investigation into apparent enforced disappearance of "Billy" welcome, but much more is needed. International Commission of Jurists, Amnesty International, and Human Rights Watch. Available at: https://www.amnesty.org/ download/Documents/ASA3987022018ENGLISH.pdf.

kk Asia Indigenous Peoples Pact (AIPP). 2013. When can we go back! AIPP. Accessed April 17, 2018. Available at: https://vimeo.com/73918768; Forest Peoples Programme. 2018. Thailand: Uphold Art. 70 of the 2017 Constitution and Strengthen the Implementation of Cabinet Resolution of 3 Aug. 2010 re Restoration of the Karen Traditional Livelihood; Protect the Rights of Indigenous Peoples: Statement of solidary with the Indigenous Karen of the Kaeng Krachan Forest. Forest Peoples Programme, Chiang Mai. Available at: https:/www.forestpeoples.org/sites/default/ files/documents/KKNCE_Thailand_FINAL-V2.pdf; Amnesty International. 2018. Let me return home to die: Al Thailand's Solidary Action for Grandpa Kor-ee. Amnesty International. Accessed July 5, 2018. Available at: https://www.amnesty. or.th/en/latest/news/125/. 


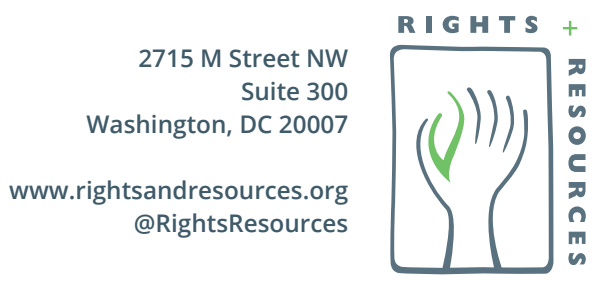

